NBER WORKING PAPER SERIES

\title{
IMPORTING POLITICAL POLARIZATION? THE ELECTORAL CONSEQUENCES OF RISING TRADE EXPOSURE
}

\author{
David Autor \\ David Dorn \\ Gordon Hanson \\ Kaveh Majlesi \\ Working Paper 22637 \\ http://www.nber.org/papers/w22637
NATIONAL BUREAU OF ECONOMIC RESEARCH
1050 Massachusetts Avenue
Cambridge, MA 02138 \\ September 2016, Revised December 2017
}

\begin{abstract}
We are grateful to Elhanan Helpman, Gary Jacobson, Nolan McCarty, John McLaren, and Zoli Hajnal for comments and Robert Anderson, Ante Malenica, Evan Soltas, and Michael Wong for excellent research assistance. Autor, Dorn and Hanson acknowledge funding from the National Science Foundation (SES-1227334) and the Russell Sage Foundation (RSF-85-12-07). Autor also acknowledges funding from the Alfred P. Sloan Foundation (\#2011-10- 120) and Dorn also acknowledges funding from the Swiss National Science Foundation (BSSGI0-155804 and CRSII1- 154446). The views expressed herein are those of the authors and do not necessarily reflect the views of the National Bureau of Economic Research.
\end{abstract}

NBER working papers are circulated for discussion and comment purposes. They have not been peer-reviewed or been subject to the review by the NBER Board of Directors that accompanies official NBER publications.

(C) 2016 by David Autor, David Dorn, Gordon Hanson, and Kaveh Majlesi. All rights reserved. Short sections of text, not to exceed two paragraphs, may be quoted without explicit permission provided that full credit, including $(\odot$ notice, is given to the source. 
Importing Political Polarization? The Electoral Consequences of Rising Trade Exposure David Autor, David Dorn, Gordon Hanson, and Kaveh Majlesi

NBER Working Paper No. 22637

September 2016, Revised December 2017

JEL No. D72,F14,H11

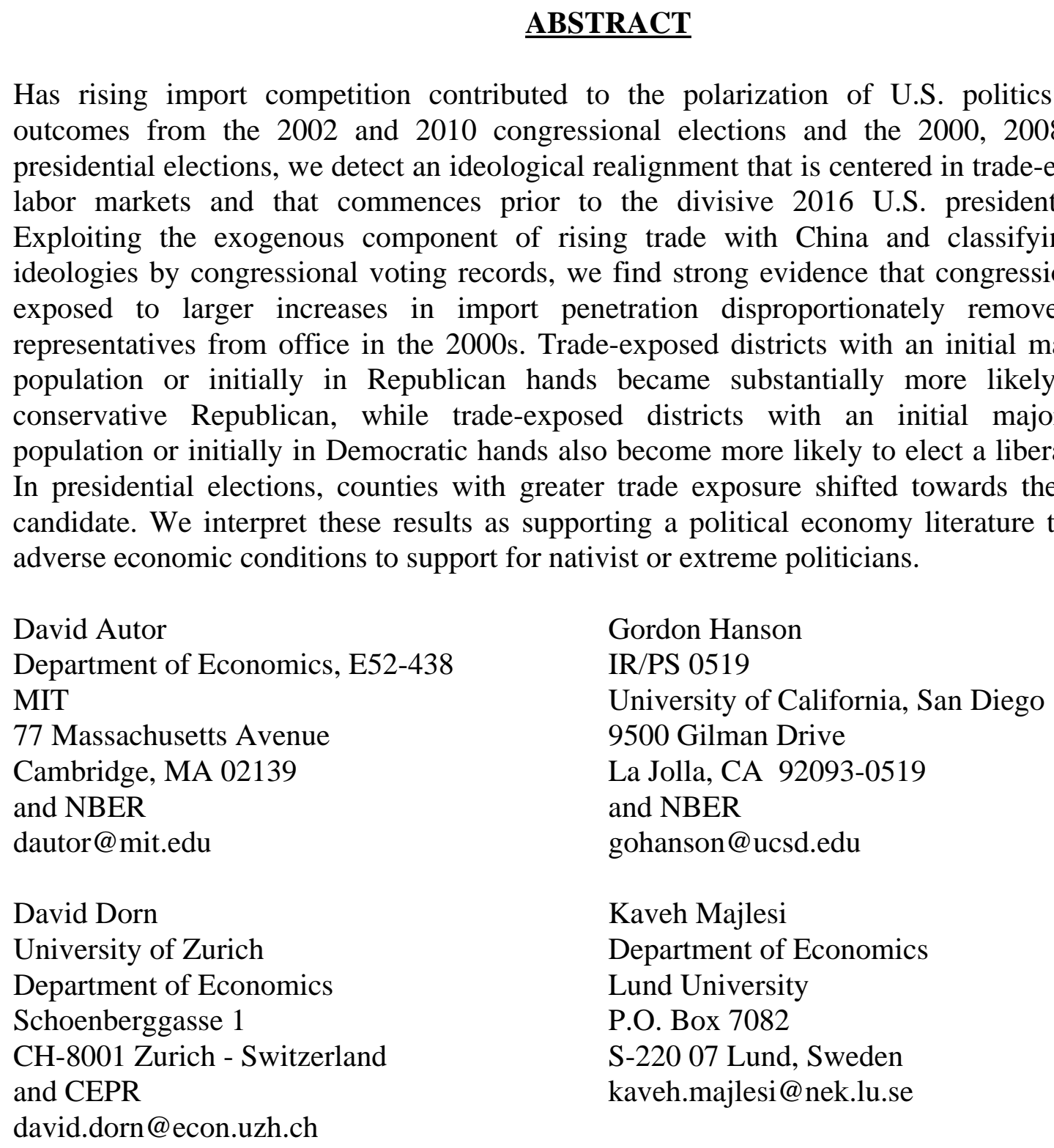




\section{Introduction}

The ideological divide in American politics is at a historic high. DW-Nominate scores (Poole and Rosenthal, 1985 and 1991), which rank congressional legislators on a liberal-conservative scale according to their roll-call votes, show that the voting gap between congressional Democrats and Republicans started widening in the mid 1970s and is now larger than at any point since the series began in 1879 (McCarty et al., 2006). ${ }^{1}$ A sizable rightward shift among congressional Republicans and a modest leftward shift among congressional Democrats has left few centrists in either party. The 2000s also saw greater polarization in the policy preferences of American voters. Whereas in the 1990s and early 2000s, roughly half of respondents took moderate positions on prominent political issues, by the late 2000s the centrist share had shrunk to under forty percent, as individuals adopted more strident views on the left or right (Pew Research Center, 2014; Gentzkow, 2016).

The causal linkages between specific economic shocks and sustained increases in partisanship remain poorly understood. Mian et al. (2014) find that while DW-Nominate scores rise following financial crises, these movements are temporary. ${ }^{2}$ Intriguingly, the widening ideological divide in Congress closely tracks rising U.S. income inequality (Voorheis et al., 2016). Yet, the coincidence of these two phenomena does not reveal which underlying shocks intensify partisanship. The rise in political polarization appears not causally related to the structure of primary elections, rule changes in Congress, gerrymandering, or immigration. ${ }^{3}$ Like the rise in income inequality (Katz and Autor, 1999), polarization may be the result of multiple causal factors. Yet in sharp contrast to research on inequality, we do not know which factors should populate this list.

In this paper, we examine whether the exposure of local labor markets to increased foreign competition and to other economic shocks has contributed to rising political polarization in the U.S. We begin by documenting the effect of exposure to rising manufacturing imports from China on the political values of voting-age adults across U.S. regions in survey data for 2004 to 2014. These effects underscore that trade shocks may have political and electoral consequences. Next, in our core analysis, we estimate the impact of greater Chinese import competition on changes in the ideological position of congressional legislators over 2002 to 2010. Finally, we expand the time frame of our analysis by considering how greater trade exposure affected presidential voting at the county level

\footnotetext{
${ }^{1}$ In the 1990s and especially the 2000s, greater polarization is also evident in the content of political speech used by Democratic and Republican legislators (Gentzkow et al., 2016).

${ }^{2}$ Their analysis spans 1879 to 2010. Over the 1948-2008 subperiod, financial crises are followed by increases in voter identification with more extreme ideological positions. For related analysis of Europe, see Funke et al. (2015).

${ }^{3}$ See Gelman et al. (2008), McCarty et al. (2006, 2009), and Barber and McCarty (2015). Other factors potentially related to polarization include intensified media partisanship (DellaVigna and Kaplan, 2007; Levendusky, 2013; Prior, 2013) and stronger ideological sorting of voters by party (Levendusky, 2009).
} 
over 2000 to 2016. These exercises allow us to evaluate whether adverse shocks related to trade or other forces cause voters to express more extreme beliefs and to replace moderate legislators with ones who lean towards either end of the political spectrum.

The appeal of studying the China trade shock is the abundant evidence linking foreign competition to the decline in U.S. manufacturing jobs. While in earlier decades, manufacturing helped workers without a college degree reach the middle class, the sector's steep decline has left U.S. employment more partitioned between highly-paid professional occupations and low-wage service jobs (Autor and Dorn, 2013). Industries more exposed to trade with China have seen higher exit of plants (Bernard et al., 2006), larger contractions in employment (Pierce and Schott, 2016; Acemoglu et al., 2016), and lower incomes for affected workers (Autor et al., 2014; Galle et al., 2017). The local labor markets that are home to more-exposed industries have endured sustained job loss and increases in unemployment, non-participation in the labor force, and uptake of government transfers (Autor et al., 2013), as well as declines in tax revenues (Feler and Senses, 2016). The speed with which the trade shock unfolded sharpened its impact. The steepest increase in U.S. imports occurred just after China's accession to the World Trade Organization in 2001; China's share of world manufacturing exports surged from $4.8 \%$ in 2000 to $15.1 \%$ in 2010, before reaching $18.3 \%$ in 2014 . The concentrated impact of the China shock on specific industries and regions makes the economic consequences of trade acutely recognizable and therefore politically salient (Margalit, 2011).

Amid this expansion of trade, U.S. politics have continued to polarize. Moderate Democrats have become increasingly rare in the House of Representatives while Tea Party and like-minded conservatives have risen to prominence in the GOP (Madestam et al., 2013). Ideological divides among voters by race and education have also widened, most notably a shift of less-educated whites towards Republican candidates and policy positions (Pew Research Center, 2016). ${ }^{4}$

To perform our analysis, we must address two empirical challenges. One is created by the redrawing of U.S. congressional districts after each decennial census. To study changes in the ideology of legislators representing particular districts, we are confined to periods within which district boundaries are fixed. Yet, changes in legislative voting behavior occur mostly through the turnover of elected officials (Lee et al., 2004), which happens infrequently. To balance the competing demands of stable boundaries for congressional districts and sufficient turnover of legislators, we study the longest period possible without redistricting after China's WTO accession, which is 2002 to 2010. Our later analysis of changes in presidential voting spans 2000 to 2016, a period that

\footnotetext{
${ }^{4}$ For analysis of the rise of right-wing populism in high-income countries - and its particular appeal to less-educated men - see Inglehart and Norris (2016) and Gidron and Hall (forthcoming). For broader analysis of populism, see Rodrik (2017).
} 
brackets our congressional-district sample and thus serves as a robustness check on the time frame for our results.

A second empirical challenge is that local labor markets, which we take to be Commuting Zones $(\mathrm{CZs})$, do not map one-to-one into congressional districts. Whereas CZs aggregate contiguous counties, gerrymandering creates districts that often span parts of several commuting zones. We resolve this issue by dividing the continental U.S. into county-by-congressional-district cells, attaching each cell to its corresponding $\mathrm{CZ}$, and weighting each cell by its share of district population. To measure regional trade exposure, we use the change in industry import penetration from China, weighting each industry by its initial share of $\mathrm{CZ}$ employment. We isolate the component of U.S. import growth that is driven by export-supply growth in China rather than U.S. product-demand shocks following the identification strategy in Autor et al. (2014) and Acemoglu et al. (2016).

To set the stage for our study, we use survey data from the Pew Research Center to examine the political beliefs of voting-age adults on major issues in U.S. politics. Over the 2004 to 2014 period, respondents in CZs that were more exposed to import competition from China became more likely to take positions on the right of the political spectrum. This analysis offers a preliminary indication that greater foreign competition affects the ideological positioning of political actors.

Turning to our main focus of electoral outcomes in congressional districts, we examine the impact of exposure to trade shocks on the ideological composition of elected legislators. ${ }^{5}$ We detect strong evidence of a polarization effect: negative economic shocks increase the relative electoral success of non-centrist politicians on either side of the ideological spectrum. Holding constant political conditions in 2002 - including the party in power, the vote share of the winning party, and the DW-Nominate score for the political orientation of the initial office holder - districts exposed to larger increases in import competition were much less likely to elect a moderate legislator in 2010. Consistent with Lee et al. (2004), the change in ideology is due not to changes in the voting behavior of existing office holders but to the election of new candidates. These new legislators tended to occupy ideological extremes, especially on the right. Greater trade exposure made districts initially in Republican hands substantially more likely to elect a GOP conservative, and, in some specifications, made initially Democratic districts more likely to elect a liberal Democrat.

Our finding that trade shocks help conservative politicians, particularly in initially Republican districts, may seem paradoxical in light of the GOP's history of free-trade advocacy (Destler, 2005), Donald Trump's 2016 presidential election victory notwithstanding. One mechanism through which

\footnotetext{
${ }^{5}$ To align ourselves with the literature, we verify the presence of an anti-incumbent effect in our data. A large literature, beginning with Fair (1978), finds that economic downturns hurt sitting politicians and their parties. Voters also punish incumbents for negative outcomes caused by import competition (Margalit, 2011; Jensen et al., 2016).
} 
these shocks may help conservative legislators is that economic adversity can increase support for nativist politicians (Inglehart and Norris, 2016) who compete electorally by encouraging voters to identify with their racial or ethnic group (Hutchings and Valentino, 2004). Because greater trade exposure increases local uptake of government transfers (Autor et al., 2013) and reduces local tax revenues (Feler and Senses, 2016), it is likely to intensify competition for government funds. In the U.S., support for the provision of public services tends to divide along racial and ethnic lines (Alesina et al., 1999). These divisions are embodied in the Tea Party movement, which political scientists view as rejecting multiculturalism and objecting to government benefits being captured by groups defined by race, ethnicity, nativity, and religion (Parker and Barreto, 2013; Tesler, 2013). To the extent that white voters disadvantaged by changes in economic conditions see conservative Republicans as favoring their interests over those of other groups - while disadvantaged minority voters see liberal Democrats as their champions - the political response to a common shock may vary according to race. In support of this mechanism, we find that in response to an increase in import competition, trade-affected regions with an initial population majority of non-Hispanic whites became more likely to elect a conservative Republican, whereas trade-affected districts without a white majority became more likely to elect a liberal Democrat. Adverse economic shocks thus appear to abet the election of more extreme politicians by encouraging voters to separate according to group identity.

The resource-competition explanation may be incomplete, however. Because right-wing populist movements tend to arise during times of economic hardship (de Bromhead et al. 2013; Mughan et al., 2003), their animus towards foreigners and minorities may stem in part from political opportunism. Glaeser et al. (2005) model how politicians may engage in strategic extremism (e.g., inflaming wedge issues) to raise voter turnout and campaign contributions among their core supporters. Although we cannot fully differentiate this opportunism-based explanation for polarization from the alternative resource-based explanation, we find that both voter turnout and individual campaign contributions rose differentially in districts that were more exposed to trade, as consistent with strategic extremism. One alternative explanation that we can reject is that our findings are simply a byproduct of a secular trend favoring conservatives. The fact that trade shocks led to ideological polarization means that ideologically extreme candidates of both parties benefited at the expense of political moderates - though conservative Republicans have benefited disproportionately.

Our results that trade shocks lead to a net rightward shift in voter political beliefs and in the voting behavior of congressional legislators contrast with Che et al. (2015), who find that over 1992 to 2010 U.S. counties exposed to greater import competition from China had larger increases in vote shares for Democratic congressional candidates. Two difficulties in interpreting the Che et 
al. (2015) findings are that gerrymandering leaves many counties fractured across districts, which makes county vote shares a noisy predictor for who wins congressional elections, and that candidates within parties vary widely in their ideology, which makes congressional vote shares an imperfect indicator of voter ideological preferences. To recast our analysis in terms of vote shares without facing these interpretational difficulties, we examine the impact of economic shocks on presidential voting. Controlling for local economic and demographic conditions in 2000, we find that over the 2000 to 2016 period, counties with a larger increase in trade exposure saw a larger increase in the share of votes won by the Republican presidential candidate. These findings align with our results on net rightward shifts in voter beliefs and legislator ideology.

The U.S. is far from alone in seeing economic adversity increase support for right-wing politicians. During the Great Depression, far-right movements had greater success in European countries that had more prolonged downturns (de Bromhead et al., 2013). Today, French and German regions more exposed to trade with low-wage countries have seen larger increases in vote shares for the extreme right (Malgouyres, 2014; Dippel et al., 2015), British regions more exposed to trade with China voted more strongly in favor of leaving the EU (Colantone and Stanig, 2016a), and European regions more exposed to the Great Recession saw a greater rise in voting for anti-establishment Euroskeptic parties (Algan et al., 2017). Our work is distinct from existing literature in two dimensions, first in demonstrating that trade shocks have generated first-order shifts in the ideology of elected representatives in the highest offices; second, in documenting a polarized response to these economic shocks - right-leaning, majority-white areas move right, whereas left-leaning, majority-minority areas tend to move more to the left.

Other related work includes studies of how congressional representatives vote on trade legislation. ${ }^{6}$ Specifically on the impact of import competition from China, Feigenbaum and Hall (2015) find that in the 1990s and 2000s, average support for protectionist trade bills is stronger among politicians whose districts experience larger increases in trade exposure. Similarly, Kleinberg and Fordham (2013) and Kuk et al. (2015) find that representatives from congressional districts harder hit by the China trade shock are more likely to support foreign-policy legislation that takes a hard line against China. Because this literature studies cross-sectional rather than over-time variation in legislative voting across districts, it does not address whether these economic shocks have induced changes in political outcomes.

In section 2, we describe our data on political beliefs and electoral outcomes, and next summarize our data on local labor markets in section 3. In section 4 , we present our empirical results on the

\footnotetext{
${ }^{6}$ See, e.g., Bailey and Brady (1998), Baldwin and Magee (2000), Hiscox (2002), and Milner and Tingley (2011). On trade exposure and support for protectionism in Europe, see Colantone and Stanig (2016b).
} 
impacts of economic shocks on voter beliefs, legislative voting behavior, and presidential voting, while examining mechanisms behind these impacts in Section 5. Section 6 considers the political consequences of economic shocks beyond trade. Section 7 concludes.

\section{Measuring Political and Electoral Outcomes in U.S. Regions}

\subsection{Changes in Voter Beliefs on Political Issues}

To measure how the ideology of prospective voters has changed over time by region, we use data from the Pew Research Center. ${ }^{7}$ Pew periodically asks U.S. adult survey participants a consistent set of ten questions about their political beliefs (see Appendix Table A1). In each question, participants choose which of two opposing statements on a topic best reflects their opinion, where each statement represents a traditional left- or right-leaning position. For example, the first pair of statements is "government is almost always wasteful and inefficient" versus "government often does a better job than people give it credit for." Subsequent questions cover government regulation of business, corporate profits, government assistance to the poor, environmental regulations, the role of the military in national security, and attitudes toward African Americans, immigration, and homosexuality. By coding each agreement with the left-leaning and right-leaning statements as -1 and +1 , respectively, Pew constructs a measure of the left-right distribution of political beliefs ranging from -10 to 10 , which we refer to as the Pew ideology score. ${ }^{8}$ We elect to use data on political beliefs, rather than party identification, because beliefs are directly reflective of ideology and are less subject to idiosyncratic changes in voter attachment to political parties (Abramowitz and Webster, 2016). ${ }^{9}$

We obtained from Pew unpublished geocoded survey microdata for its surveys in 2004, 2011, 2014, and 2015, in which participants were asked about the 10 pairs of belief statements, yielding a pooled sample of 20,785 observations. ${ }^{10}$ The data show both a rightward shift and a strong polarization in participant political beliefs over the 2000s. ${ }^{11}$ In Table 1, the mean ideology score

\footnotetext{
${ }^{7}$ Other surveys of political attitudes include the American National Election Studies, the General Social Survey, and the Cooperative Congressional Election Survey. None are suitable for our purposes. The first two have commuting zone-level sample sizes that are very small, while the third does not commence until late in our study period.

${ }^{8}$ For the full Pew ideological consistency scale, see Pew Research Center (2014, p. 82). If respondents do not have a preference between the two statements (i.e., they say they disagree with both or do not know), their answer to this statement is coded as a 0 for the construction of the Pew ideology score.

${ }^{9}$ Other work that uses Pew data to study polarization includes Gentzkow et al. (2016). Gentzkow (2016) discusses alternative measures of political polarization used in the literature.

${ }^{10}$ We retain all survey respondents who reside in the 48 mainland states, and drop the $0.6 \%$ of observations that have incomplete demographic information. Microdata prior to 2004 were unavailable.

${ }^{11}$ Survey data that measure respondents' views of the other party rather than their views on specific issues find a sharp rise in polarization in the mid-1990s - suggesting a rise in party salience. Data that track polarization of specific issue positions, however, do not find a rise of polarization until the mid-2000s (Gentzkow, 2016).
} 
increased from -0.91 to -0.62 from 2004 to 2015, corresponding to one more survey item with a right-leaning answer for every six respondents. ${ }^{12}$ The fraction of participants whose ideology was centrist (Pew score of -2 to 2) fell from 48.6\% in 2004 to $42.0 \%$ in 2011 and declined further to $37.7 \%$ in 2015. By contrast, the fraction of participants whose ideology was mostly or strongly conservative (Pew score of 3 to 10) rose from $18.7 \%$ in 2004 to $26.9 \%$ in 2015, with most of this change occurring by 2011. The fraction whose ideology was mostly or strongly liberal (Pew score of -3 to -10 ) rose more modestly from $32.7 \%$ to $35.5 \%$ over the 2004-2015 time frame. Given the similarity of survey responses in 2014 and 2015, we pool participants for these two years in our later regression analysis.

Table 1: Share of Population by Pew Ideology Score, 2004 to 2015

\begin{tabular}{|c|c|c|c|c|}
\hline Year & $\begin{array}{c}\text { Mean Score } \\
(1) \\
\end{array}$ & $\begin{array}{c}\% \text { Liberal } \\
(2)\end{array}$ & $\begin{array}{c}\% \text { Moderate } \\
\text { (3) }\end{array}$ & $\begin{array}{c}\% \text { Conserv } \\
(4) \\
\end{array}$ \\
\hline 2004 & -0.91 & 32.7 & 48.6 & 18.7 \\
\hline 2011 & -0.31 & 31.3 & 42.0 & 26.7 \\
\hline 2014 & -0.59 & 34.5 & 39.3 & 26.2 \\
\hline 2015 & -0.62 & 35.5 & 37.7 & 26.9 \\
\hline$\Delta 2004-15$ & 0.29 & 2.7 & -10.9 & 8.2 \\
\hline
\end{tabular}

Notes: The Pew Ideology score ranges from -10 (most liberal to +10 (most conservative). Columns 2-4 define liberals as those with scores of -10 to -3 , moderates as those with scores from -2 to 2 , and conservatives as those with scores from 3 to 10 . Sample sizes for survey participants who reside in the 48 mainland states and who have complete demographic information are 1,994 in 2004, 3,016 in 2011, 9,868 in 2014, and 5,907 in 2015. Observations are weighted by survey weights.

Changes in political beliefs vary markedly by race and ethnicity. The rightward shift in ideology evident in Table 1 can be attributed almost entirely to the preferences of non-Hispanic whites (see Appendix Table A2). Whereas their mean ideology score increased from -0.62 to 0.08 from 2004 to 2015 (corresponding to one more right-leaning answer for every three whites), the mean ideology score of Hispanics and non-Whites shifted leftwards from -1.66 to -2.01 (one more left-leaning answer for every four respondents), thus doubling the ideological distance between whites and other groups. The share of whites with conservative beliefs rose sharply from $22.2 \%$ to $34.9 \%$, while the prevalence of liberal beliefs increased from $37.7 \%$ to $44.3 \%$ among Hispanics and non-Whites. These patterns reveal increasing polarization of beliefs between left and right and between non-Hispanic whites and other groups.

\footnotetext{
${ }^{12}$ Each survey item that generates a right-leaning instead of a left-leaning answer raises the ideology score by 2 points $(+1$ instead of -1$)$; the increase in average score by 0.29 thus corresponds to $0.29 / 2=0.15$ additional right-leaning answers per person.
} 


\subsection{Voting Behavior of Congressional Legislators}

\subsubsection{Measuring Legislator Ideology}

Our analysis of congressional elections covers 2002 to 2010. Within this period, congressional districts are defined consistently, which allows us to examine how elected representatives change over time for geographically stable groups of voters. The 2002 and 2010 elections are respectively the first and last congressional elections whose districts are based on the 2000 Census, making this the longest time period we can examine following China's 2001 WTO accession. ${ }^{13}$ The extended time frame helps generate sufficient turnover in legislators for our analysis of changes in legislative behavior to be meaningful. Because the voting behavior of individual legislators tends to be stable over time (Poole and Rosenthal, 1997), changes in legislator ideology occur primarily through legislator turnover (Lee et al., 2004). Turnover from one congressional election to the next is low both because many House seats tend to be safe for candidates from a particular party and because sitting incumbents are unlikely to face challenges from within their own party (see, e.g., Levitt and Wolfram, 1997). A longer time span raises the likelihood of turnover from retirements and from back-and-forth party switches in House seats that occur between midterm and presidential elections and between changes in party control over the White House. ${ }^{14}$ By $2010,48 \%$ of the congressional seats in our sample were held by a legislator different from the one who held the seat in 2002 .

To measure variation in the political orientation of congressional representatives, we use PooleRosenthal DW-Nominate scores (Poole and Rosenthal, 1985; McCarty, Rosenthal, and Poole, 2006), which are widely applied in political science and are the foundation for analyses of political polarization in Congress. DW-Nominate uses roll-call (or recorded) votes in the U.S. House of Representatives and the U.S. Senate to categorize elected officials on an ideological scale from liberal to conservative. This score is based on a multidimensional scaling technique in which one assumes that: (i) each piece of legislation can be represented by two points (one for a yea vote, one for a nay vote) in Euclidean space; (ii) each legislator has a well-behaved utility function defined over this space; (iii) and each legislator chooses her vote non-strategically to maximize her static utility, such that one can use a static random utility model to characterize each legislator's yea-or-nay choice. If one observes a common set of legislators voting on many bills, one can estimate the parameters of the utility function and rank legislators in each of the Euclidean dimensions.

\footnotetext{
${ }^{13}$ These two years are each the first midterm election of a first-term president (George W. Bush in 2002, Barack Obama in 2010), making them similar in terms of their place in the political cycle.

${ }^{14}$ Midterm elections tend to boost congressional candidates from the party that does not hold the White House (Fair, 1996; Lewis-Beck and Stegmaier, 2000), while presidential elections tend to help congressional candidates from the same party as the winning presidential candidate (Erikson, 1988).
} 
Because DW-Nominate is estimated using roll-call votes for all 113 U.S. Congresses, each of which contain a large number of overlapping members from one Congress to another, parameters are comparable across time. For most of U.S. history, DW-Nominate scores exhibited little gain in explanatory power when allowing for more than two Euclidean dimensions; since the early 1980s, however, by which time the post-1964 realignment of Southern conservatives from the Democratic to the Republican Party was largely complete, there is only modest gain in going beyond one dimension (McCarty, Rosenthal, and Poole, 2006). The DW-Nominate score that we use is the position of legislators along the primary dimension, which Poole and Rosenthal (1997) describe as a measure of liberal-conservative ideology. Henceforth, we refer to the first dimension of DW-Nominate as simply the Nominate score. For presentation, we rescale the Nominate score by multiplying by 100 .

Figure 1: Polarization in Nominate Scores

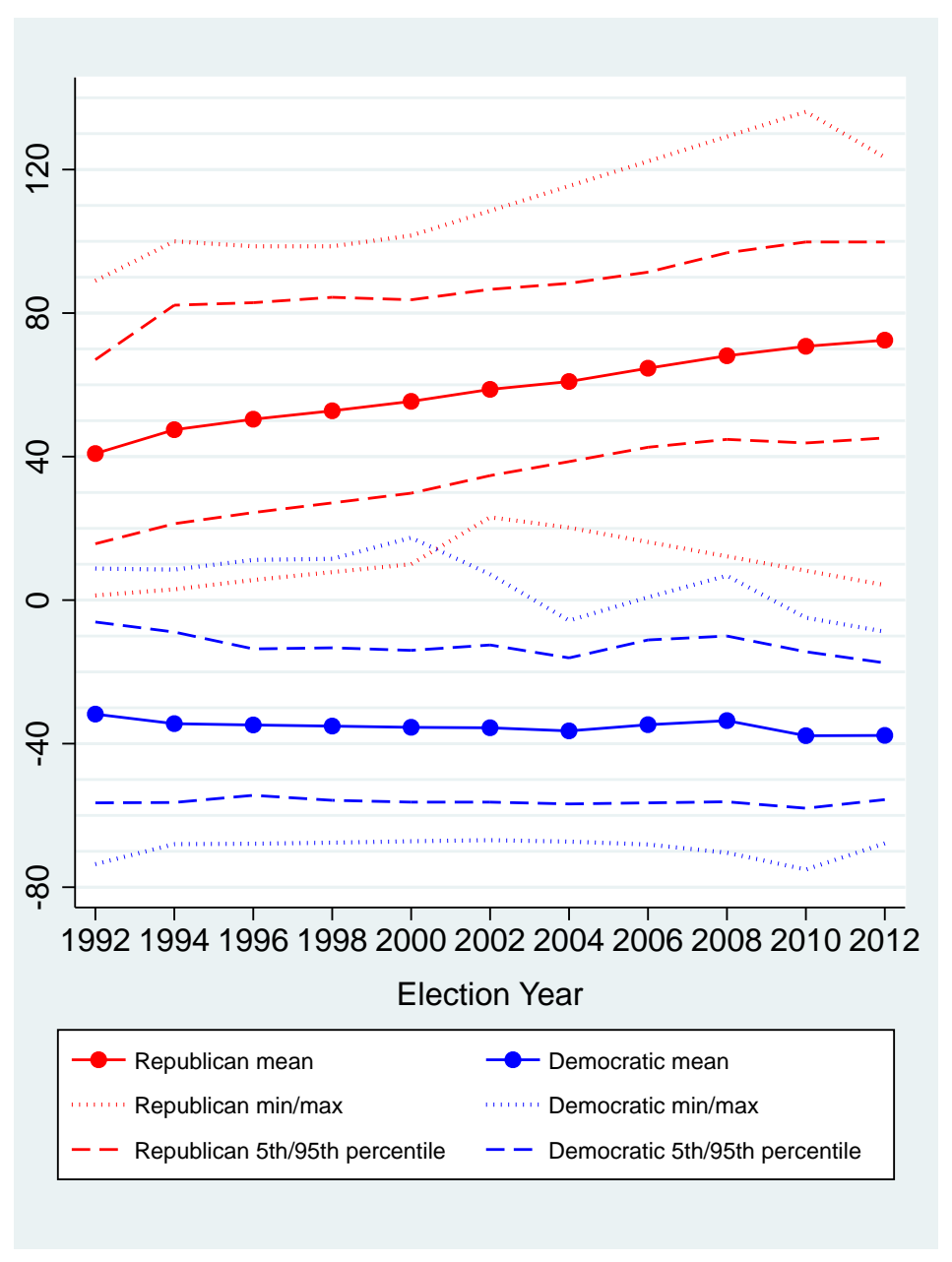

Over the 113 U.S. congresses, the scaled Nominate score in the House is roughly centered on zero $($ mean $=2$, standard deviation $=38)$, where the average value over time for each legislator is 
constrained to lie between -100 (most liberal) and 100 (most conservative). Our convention is to define the year to be the calendar year in which representatives are elected, which precedes the two-year congressional term on which Nominate scores are based, such that the Nominate scores we ascribe to 2002 are based on roll-call votes for the 108th Congress that occurred between January 2003 and January 2005.

Figure 1 shows both the central tendency and the spread of Nominate scores for Democratic and Republican representatives from 1992 to 2012, illustrating the widening partisan divide in Congress. Republican legislators have become markedly more conservative in their voting on legislation, with their average Nominate score rising from 41 in 1992 to 72 in 2010, a change equal to 0.82 of the standard deviation of the Nominate score for all 113 congresses. Democrats, for their part, have become somewhat more liberal, with average Nominate scores falling from -32 to -38 over the same period, a 0.16 standard-deviation change. Notably, there is no ideological overlap between the parties after 2000: the most conservative Democrat is more liberal than the most liberal Republican.

One might wonder whether the increasing polarization of Nominate scores across Representatives of the two parties evident in Figure 1 has coincided with more polarized vote counts in congressional districts, i.e., Republicans increasingly winning more lopsided victories in right-leaning districts and Democrats winning with greater margins in left-leaning districts. During the 1990s, mean vote shares increased both for winning Republicans and winning Democrats, but the trend reversed during the 2000s, when vote shares fell for winning candidates of both parties while the ideological positions of elected candidates continued to diverge (see Appendix Figure A1). One explanation for the reversal of the 2000s is that the parties' more ideologically extreme candidates deterred the support of moderate voters, resulting in narrower victories. ${ }^{15}$ Since across congressional districts voters choose between distinct sets of candidates who may represent different ideologies within the same party, it is difficult to interpret party vote shares as proxies of elected representatives' or voters' political positions. This observation motivates our choice to analyze changes in the Nominate scores of elected representatives, rather than changes in party vote shares, as in Che et al. (2015). It will turn out that were we to analyze only party vote shares, we would erroneously conclude that trade shocks had a negligible effect on the ideological composition of Congress. When we measure the selection of representatives according to revealed ideology rather than exclusively party affiliation, a distinctly different picture emerges.

\footnotetext{
${ }^{15}$ An alternative interpretation would be that Republicans have picked up seats in the House in more closely competitive districts, with correspondingly smaller victory margins. However, this logic would also imply that Democrats won their races by larger vote margins, which is counterfactual to the observed patterns.
} 


\subsubsection{Nominate Scores for Specific Issues, Including Trade}

Given that congressional representatives vote on legislation that spans a wide array of subjects, it is fair to question whether a scalar measure of ideology is capable of summarizing their voting behavior. To investigate this concern, we estimated Nominate scores from 2002 to 2010 (i.e., from the 108th Congress beginning in 2003 to the 112th Congress beginning in 2011) for seven major issue areas separately: budgetary issues, regulation, domestic social policy, defense and foreign policy, tariffs and trade regulation, immigration and naturalization, and globalization (trade and immigration combined). Appendix Table A4 reports correlations across legislators between DW-Nominate scores (which cover all issue areas) and these seven issue-specific Nominate scores. We report correlations for level values in 2002 and 2010 and for changes in values over 2002 to 2010. The correlations among scores in levels (changes) are above $0.92(0.84)$ for all issues. This strong continuity across topics in voting and in changes in voting suggests that the scalar DW-Nominate measure of ideology comprehensively characterizes the legislative positioning of elected representatives.

Although Republicans are seen as being more favorable towards free trade than Democrats, the stance of the right wing of the GOP on trade is more equivocal than the issue-specific Nominate scores in Appendix Table A4 may suggest. Legislators affiliated with the Tea Party movement, for instance, tend to espouse support for free trade as a concept but to reject actual trade agreements, which as international treaties they view as compromising national sovereignty. ${ }^{16}$ Members of the Republican Liberty Caucus and the House Freedom Caucus, two prominent groups of right-wing GOP legislators in the House, opposed the Trans-Pacific Partnership, a trade agreement that would have been the most significant U.S. trade deal since NAFTA. ${ }^{17}$ Suspicion of trade agreements on the far right is not historically novel. The conservative stalwart Senator Barry Goldwater opposed the Trade Expansion Act of 1962, which granted the president the authority to negotiate tariff reductions under the Kennedy Round of the General Agreement on Trade and Tariffs. ${ }^{18}$ A combination of economic liberalism on domestic policy and economic nationalism on foreign policy evident among the Republican's right flank is characteristic of right-wing populist movements internationally (Mughan et al., 2003). Political economists have long recognized a connection between protectionism and economic nationalism. Johnson (1965) posited that protectionism arises from a "collective preference for industrial production," which may give rise to pressure for mercantilist policies. Although few

\footnotetext{
${ }^{16}$ Although trade took a central role in the 2016 presidential campaign, such prominence is unusual. In the typical congressional session, there are relatively few votes on trade-related topics. Of the 1,218 roll-call votes in the 108 th Congress (2003-2005), just 23 were related to tariffs and trade regulation, and of the 1,602 roll-call votes in the 112 th Congress (2011-2013), only 11 were trade-related.

${ }^{17}$ See, e.g., Matt Fuller, "House Conservatives Are Trying to Kill the Lame-Duck Session," HuffPo, March $29,2016$.

${ }^{18}$ See Patrick J. Buchanan, "Free Trade vs. the Republican Party," American Conservative, May, 20, 2016.
} 
conservative House Republicans espouse mercantilism explicitly, the "America First" nationalism which has become a rallying cry for the right (Judis, 2016) conflicts with the globalism implicit in multilateral trade accords. In terms of public opinion, GOP voters are skeptical of trade accords. A 2016 Pew Research Center survey of registered voters shows that $53 \%$ of voters who identify or lean Republican, as compared to $34 \%$ of voters who identify or lean Democrat, report that free-trade agreements have been a "bad thing for the U.S." We take this evidence to mean that supporting a right-wing Republican does not equate to supporting further expansion of international trade.

\subsubsection{County-by-Congressional-District Cells}

To organize our data so as to map economic outcomes in commuting zones to political outcomes in congressional districts, we define the geographic unit of analysis to be the county-by-congressionaldistrict cell. The building blocks of congressional districts are census tracts, whose amalgamation allows officials to construct districts that meet the constitutional requirement of each holding approximately $1 / 435^{\text {th }}$ of the U.S. population. The area that constitutes a district must be contiguous and lie within the boundaries of a state but may combine sections of multiple counties. Counties, in turn, are the building blocks of CZs, which combine adjoining locations that have the commuting structure of a local labor market (Tolbert and Sizer, 1996; Dorn, 2009). We ascribe to each countydistrict cell the CZ-level trade shock that corresponds to the county and weight each cell by its share of the adult population in the district, such that each congressional district has equal weight in the analysis. If a district spans multiple CZs, the economic factors that are mapped to the district will be a population-share-weighted average of the values in these $\mathrm{CZs}^{19}$

To illustrate how we construct country-by-congressional-district cells, consider North Carolina's 12th congressional district, which connects parts of the cities of Charlotte, Greensboro and WinstonSalem along a narrow corridor (see Appendix Figure A2). Rowan County overlaps with the 12th district in its center, but also with the 5th district in its Northwest, and with the 8th district in its Southeast. Our data contain a separate observation for each of these county-district cells. To each cell, we attach information on the elected representatives for the corresponding district (for cells in Rowan Country from the 5th, 8th, or 12th), and the economic conditions of the commuting zone

\footnotetext{
${ }^{19}$ From the full sample of 435 congressional districts, we omit Alaska's one congressional district and Hawaii's two congressional districts because CZs are difficult to define for these states. We also omit the one district for Vermont, whose elected congressional representative over the sample period is an independent and thus is attached to neither major political party. In the remaining territory, the two states of Texas and Georgia carried out some intercensal redistricting during the 2000s, which requires us to omit a set of county-district cells that sum to 15 congressional districts (nine of these districts are in Texas and five are in Georgia, representing about one third of districts in each state). The resulting set of 3,504 county-district cells covers 416 congressional districts, or approximately $96 \%$ of the U.S. population, over the period 2002 to 2010. See Table A3 in the Appendix for details.
} 
(Charlotte) to which the county (Rowan) belongs. In our analysis, the weight attached to each cell equals the cell's share of the population in its corresponding congressional district.

Data on election outcomes in county-district cells are from Dave Leip's Atlas of U.S. Presidential Elections. These data track the number of votes received by Democratic, Republican, and other candidates for Congress, the Presidency, and for other major offices in each county within each congressional district, and in each election year. ${ }^{20}$ We use these data to tabulate the number and shares of votes won by Democratic and Republican congressional candidates in each countyby-district cell in 2002 as well as the change in these values between 2002 and 2010. We record the number of registered voters and voter turnout by county, whether the winning candidates in 2002 or 2010 ran unopposed, and whether the winner of the 2002 election remained in office after the 2010 election. $^{21}$ In our analysis of presidential voting, we use county-level vote shares for presidential candidates in the two major parties in 2000, 2008, and 2016. For additional measures of the competitiveness of congressional elections, we use the Database on Ideology, Money in Politics, and Elections (Bonica, 2013), which tabulates campaign contributions by donor and recipient for all amounts in excess of $\$ 200$ using reports mandated by the Federal Electoral Commission.

\section{Measuring Local Labor Market Exposure to Trade}

Our empirical analysis employs the specification of local trade exposure derived by Autor et al. (2014) and Acemoglu et al. (2016). We measure the shock experienced by a local labor market as the average change in Chinese import penetration in that CZ's industries, weighted by each industry's share in the CZ's initial employment:

$$
\Delta I P_{i \tau}^{c u}=\sum_{j} \frac{L_{i j t}}{L_{i t}} \Delta I P_{j \tau}^{c u}
$$

In this expression, $\Delta I P_{j \tau}^{c u}=\Delta M_{j \tau}^{c u} /\left(Y_{j 0}+M_{j 0}-X_{j 0}\right)$ is the growth of Chinese import penetration in the U.S. for industry $j$ over period $\tau$, computed as the growth in U.S. imports from China during the outcome period, $\Delta M_{j \tau}^{c u}$, divided by initial absorption (U.S. industry shipments plus net imports, $\left.Y_{j 0}+M_{j 0}-X_{j 0}\right)$ in the base period 1991, near the start of China's export boom. The fraction $L_{i j t} / L_{i t}$ is the share of industry $j$ in $\mathrm{CZ} i$ 's total employment, as measured in County Business Patterns data prior to the outcome period in the year 2000.

\footnotetext{
${ }^{20}$ The Leip data on registered voters and vote totals for each candidate are broken down by both county and the congressional district.See http://uselectionatlas.org/.

${ }^{21}$ Data on registered voters are missing in 2002 and/or 2010 in Georgia, Mississippi, North Dakota and Wisconsin. These four states are omitted from the corresponding part of the empirical analysis.
} 
In (1), the difference in $\Delta I P_{i t}^{c u}$ across commuting zones stems from variation in local industry employment structure at the start of period $t$. This variation arises from two sources: differential concentration of employment in manufacturing versus non-manufacturing activities and specialization in import-intensive industries within local manufacturing. ${ }^{22}$ In all specifications, we control for the start-of-period manufacturing share within CZs so as to focus on variation in exposure to trade arising from differences in industry mix within local manufacturing.

An issue for the estimation is that realized U.S. imports from China in (1) may be correlated with industry import-demand shocks. In this case, OLS estimates of the relationship between changes in imports from China and changes in U.S. manufacturing employment may understate the impact of the pure supply shock component of rising Chinese import competition, as both U.S. employment and imports may rise simultaneously in the face of unobserved positive shocks to U.S. product demand. To identify the causal effect of rising Chinese import exposure on local-level political outcomes, we employ an instrumental-variables strategy that accounts for the potential endogeneity of U.S. trade exposure. We exploit the fact that during our sample period, much of the growth in Chinese imports stems from the rising competitiveness of Chinese manufacturers, which is a supply shock from the perspective of U.S. producers. China's lowering of trade barriers (Bai, Krishna, and Ma, 2015), dismantling of the constraints associated with central planning (Naughton, 2007; Hsieh and Song, 2015), and accession to the WTO (Pierce and Schott, 2016) have contributed to a massive increase in the country's manufacturing capacity and a concomitant rise in the country's manufacturing exports (Hsieh and Ossa, 2015).

We identify the supply-driven component of Chinese imports by instrumenting for growth in Chinese imports to the U.S. using the contemporaneous composition and growth of Chinese imports in eight other developed countries. ${ }^{23}$ Specifically, we instrument the measured import-exposure variable $\Delta I P_{i \tau}^{c u}$ with a non-U.S. exposure variable $\Delta I P_{i \tau}^{c o}$ that is constructed using data on industrylevel growth of Chinese exports to other high-income markets:

$$
\Delta I P_{i \tau}^{c o}=\sum_{j} \frac{L_{i j t-10}}{L_{u i t-10}} \Delta I P_{j \tau}^{c o}
$$

This expression for non-U.S. exposure to Chinese imports differs from the expression in equation (1) in two respects. In place of U.S. imports by industry $\left(\Delta M_{j \tau}^{c u}\right)$ in the computation of industry-level

\footnotetext{
${ }^{22}$ Differences in manufacturing employment are not the primary source of variation. In a bivariate regression, the start-of-period manufacturing employment share explains less than 40 percent of the variation in $\Delta I P_{i t}^{c u}$.

${ }^{23}$ The eight other high-income countries are those that have comparable trade data covering the full sample period: Australia, Denmark, Finland, Germany, Japan, New Zealand, Spain, and Switzerland.
} 
import penetration, it uses realized imports from China by other high-income markets $\left(\Delta M_{j \tau}^{c o}\right)$, and it replaces all other variables with lagged values to mitigate any simultaneity bias. ${ }^{24}$ As documented by Autor et al. (2016), all eight comparison countries used for the instrumental variables analysis witnessed import growth from China in at least 343 of the 397 total set of manufacturing industries. Moreover, cross-country, cross-industry patterns of imports are strongly correlated with the U.S., with correlation coefficients ranging from 0.55 (Switzerland) to 0.96 (Australia). That China made comparable gains in penetration by detailed sector across numerous countries in the same time interval suggests that China's falling prices, rising quality, and diminishing trade and tariff costs in these surging sectors are root causes of its manufacturing export growth.

A potential concern for our analysis is that it largely ignores U.S. exports to China, focusing instead on trade flows in the opposite direction. This focus is dictated by the fact that our instrument, by construction, has less predictive power for U.S. exports to China. To a first approximation, China's economic growth during the 1990s and 2000s generated a substantial shock to the supply of U.S. imports but only a modest change in the demand for U.S. exports. During our sample period, imports from China were much larger - approximately five times as large - as manufacturing exports from the U.S. to China. Our instrumental strategy should therefore identify the direct and indirect effects of increased import competition from China.

Data on international trade are from the UN Comtrade Database, which gives bilateral imports for six-digit HS products. ${ }^{25}$ To concord these data to four-digit SIC industries, we first apply the crosswalk in Pierce and Schott (2012), which assigns ten-digit HS products to four-digit SIC industries (at which level each HS product maps into a single SIC industry), and then aggregate to six-digit HS products and four-digit SIC industries (at which level some HS products map into multiple SIC entries). For this aggregation, we use data on U.S. import values at the ten-digit HS level, averaged over 1995 to 2005. Dollar amounts are inflated to dollar values in 2015 using the PCE deflator. Data on CZ employment by industry from the County Business Patterns for the years 1990 and 2000 is used to compute employment shares by industry in (1) and (2).

Appendix Table A5 summarizes our trade exposure measures which are defined at the CZ level and then matched to, variously, Pew survey respondents by $\mathrm{CZ}$ of residence, county-district cells - used in the main analysis of Congressional election outcomes - and counties for the supplementary examination of presidential elections. On average, congressional districts saw an increase in Chinese import penetration of 0.71 percentage points between 2002 and 2010 (column 2 of Appendix

\footnotetext{
${ }^{24}$ The start-of-period employment shares $L_{i j t} / L_{i t}$ are replaced by their 10 -year lag, while initial absorption in the expression for industry-level import penetration is replaced by its 3-year lag.

${ }^{25}$ See http://comtrade.un.org/db/default.aspx.
} 
Table A5). The growth in trade exposure was equally large in the slightly later period of 2004-2014 that matches to the Pew data, and somewhat larger in the earlier period of 2000-2008 which covers two presidential terms. In section 4, we use the interquartile range of the increase in trade exposure as a metric to scale estimated treatments of trade exposure on political outcomes in more versus less-exposed districts. This range is 0.49 percentage points across the full set of congressional districts. In later analysis, we incorporate additional measures of economic shocks to commuting zones, which are discussed in Appendix A.

\section{Main Results}

We examine the political consequences of exposure to import competition from China and other shocks in three stages: beginning with changes in political beliefs; next, considering changes in the ideological positioning of congressional representatives; and finally, assessing presidential voting. Across these stages, we estimate equations of the form:

$$
\Delta Y_{j \tau}=\gamma+\beta_{1} \Delta I P_{j \tau}^{c u}+X_{j t}^{\prime} \beta_{3}+Z_{j t}^{\prime} \beta_{2}+e_{j t}
$$

The dependent variable $\Delta Y_{j \tau}$ is the change in an outcome for time period $\tau$ (2004 to 2014/2015 for political beliefs, 2002 to 2010 for legislator ideology, 2000 to 2016 for presidential voting) that corresponds to region $j$ (CZ, county-congressional-district cell, county, respectively). The main variable of interest is the change in import exposure $\Delta I P_{j \tau}$ in region $j$ over period $\tau$, for which we instrument in all regressions using the variable in (2). The first set of control variables $X_{j t}$ measures start-of-period political conditions in region $j$ and the second set of controls $Z_{j t}$ measures start-of-period economic conditions and demographic characteristics that apply to region $j$.

\subsection{Impact of Trade Shocks on Political Beliefs}

We examine the impact of increased regional trade exposure on political beliefs using the Pew data presented in Section 2.1. Our analysis includes Pew surveys in 2004, 2014, and 2015, where we treat the second two years as a single time period given the similarity in responses for these two surveys (see Tables 1 and A2). Whereas the Pew survey is representative of the population at the national level, our local labor market analysis puts high demands on the data as we observe only 25 observations on average per commuting zone even when pooling data across years. ${ }^{26}$ Having

\footnotetext{
${ }^{26}$ The pooled sample of 17,706 participants includes 650 commuting zones that appear in at least one of the years and 412 commuting zones that appear both in both time periods (i.e., 2004 and at least one of 2014 or 2015 ).
} 
this caveat in mind, we proceed with an exploratory analysis that uses a CZ fixed effects variant of (3) which allows us to control for the characteristics of individual respondents in the repeated cross-sections of the Pew survey. The estimating equation takes the form:

$$
Y_{i j s}=\gamma_{j}+\gamma_{1} \Delta I P_{j \tau}^{c u} \times 1\left[s=t_{2}\right]+X_{i j s}^{\prime}\left(\gamma_{3}+\gamma_{4} \times 1\left[s=t_{2}\right]\right)+Z_{j}^{\prime} \gamma_{6} \times 1\left[s=t_{2}\right]+\epsilon_{i j s},
$$

where the dependent variable $Y_{i j s}$ is the Pew ideology score (on a scale of -10 to +10 , with higher values reflecting more conservative view) for participant $i$ who resided in commuting zone $j$ and who was interviewed in survey year $s$, with 2004 defined to be the first period, $t_{1}$, and 2014 and 2015 defined to be the second period, $t_{2} ; \gamma_{j}$ is a fixed effect for CZ $j ; \Delta I P_{j \tau}$ is the change in trade exposure over 2004 to 2014 in $\mathrm{CZ} j ; 1\left[s=t_{2}\right]$ is a dummy variable indicating whether the survey occurred in the second time period (2014 or 2015); $X_{i j s}$ is a vector of characteristics corresponding to participant ijs (a quadratic in age and dummy variables for gender, race, and three categories of education); and $Z_{j}$ is a vector of control variables for initial economic and political conditions for $\mathrm{CZ} j$ in the year 2000 (the share of manufacturing in employment in 2000, the Autor and Dorn (2013) routine-task-intensity and offshorability indexes in 2000, the county-level vote share for George W. Bush in the 2000 presidential election interacted with indicators for the party that won the majority of the county vote, and the mean and absolute mean Pew ideology scores at the CZ level in 2004). ${ }^{27}$ Because the surveys are repeated cross sections, we cannot study changes in beliefs for a longitudinal panel of participants. Instead, we include CZ fixed effects and introduce time-varying regression coefficients in (4) to examine whether average beliefs vary differentially over time within commuting zones depending on the degree of regional trade exposure. Results for the Pew sample data appear in Table 2.

\footnotetext{
${ }^{27}$ Controlling for initial Pew ideology scores at the CZ level helps account for regression to the mean in political beliefs across regions over time. By controlling for both the mean and absolute mean scores, we implicitly allow for mean reversion in the left-right dimension and in the degree of ideological extremism.
} 
Table 2: Exposure to Chinese Import Competition and Pew Ideology Scores, 2014/15 vs 2004 Dependent Variable: Change in Pew Ideology Score

\begin{tabular}{|c|c|c|c|c|c|c|c|c|c|c|c|c|c|}
\hline & $(1)$ & $(2)$ & & $\begin{array}{c}\text { Respond } \\
\text { (3) }\end{array}$ & & (4) & & $(5)$ & & $\begin{array}{c}\text { Non- } \\
\text { Hisp } \\
(6) \\
\end{array}$ & & $\begin{array}{c}\text { Minor- } \\
\text { ities } \\
(7) \\
\end{array}$ & \\
\hline $\begin{array}{l}\Delta \text { CZ Import Penetration } \mathrm{x} \\
\text { Year 2014/15 }\end{array}$ & $\begin{array}{c}0.12 \\
(0.17)\end{array}$ & $\begin{array}{l}0.49 \\
(0.31)\end{array}$ & & $\begin{array}{c}0.63 \\
(0.26)\end{array}$ & * & $\begin{array}{c}0.92 \\
(0.39)\end{array}$ & $*$ & $\begin{array}{c}1.14 \\
(0.37)\end{array}$ & $* *$ & $\begin{array}{r}1.42 \\
(0.43)\end{array}$ & $* *$ & $\begin{array}{l}-0.16 \\
(1.02)\end{array}$ & \\
\hline Estimation Method & OLS & 2SLS & & 2SLS & & 2SLS & & 2SLS & & 2SLS & & 2SLS & \\
\hline F-statistic First Stage & & 34.8 & $* *$ & 35.1 & $* *$ & 28.3 & $* *$ & 28.1 & $* *$ & 29.0 & $* *$ & 18.2 & $* *$ \\
\hline Individual Demographics & & & & yes & & yes & & yes & & yes & & yes & \\
\hline 2000 Ind/Occ Controls & & & & & & yes & & yes & & yes & & yes & \\
\hline 2000 Pres. Election Controls & & & & & & & & yes & & yes & & yes & \\
\hline
\end{tabular}

Notes: $\mathrm{N}=17,769$ in columns 1-5, $\mathrm{N}=13,197$ in column 6 and $\mathrm{N}=4,572$ in column 7 . The Pew Ideology Score has a minimum of -10 (most liberal) and maximum of +10 (most conservative). Its weighted mean is -0.91 in 2004 and -0.60 in $2014 / 15$. All regressions control for CZ and period fixed effects, and the average value and average absolute value of the 2004 Pew score in a CZ interacted with the period dummy. Controls for individual demographics in column 3 include a quadratic in age and indicators for sex, three education and race groups (non-Hispanic whites, Hispanics, all others) and three education groups (college, some college, high school and less). Industry and occupation controls in column 4 include the fraction of CZ employment in the manufacturing sector and the Autor and Dorn (2013) routine share and offshorability index of a CZ's occupations, all of which are measured in 2000 and interacted with the dummy for the 2014/15 period. Controls for the 2000 presidential election in column 5 comprise the two-party vote share of Republicans in the 2000 presidential election in a county, interacted both with a dummy for the party that won the given county and the dummy for the 2014/15 period dummy. Observations are weighted by each individual's share in the sum of Pew survey weights in a given period (2000 or 2014/15), and standard errors are clustered on CZs. $\sim \mathrm{p} \leq 0.10, * \mathrm{p} \leq 0.05$, $* * \mathrm{p} \leq 0.01$.

Column (1) of Table 2 reports the results of a parsimonious OLS regression specification that controls for $\mathrm{CZ}$ and period fixed effects and initial values of the Pew score. The coefficient on the interaction between the $\mathrm{CZ}$ trade shock and the second-period dummy is positive but small and not precisely estimated. A corresponding two-stage least squares regression in column (2) that instruments for the import exposure measure (1) with the instrument (2) has a strong first stage and a second stage estimate that is larger than the OLS result but remains marginally insignificant (t-statistic of 1.60). In Autor, Dorn and Hanson's (2013) analysis of the labor market impact of increased import competition from China, instrumental variables regressions consistently indicate more adverse impacts of trade than OLS regressions. To the extent that import shocks affect political beliefs via deteriorating labor market conditions, one would expect the greater impact of imports on ideology when moving from the OLS estimation of column (1) to the 2SLS estimation of column (2). The addition of control variables for demographic characteristics of the individual survey respondents in column (3) raises both the magnitude and precision of the coefficient estimate, which becomes statistically significant. This results suggests that demographically comparable survey respondents 
residing in commuting zones that were subject to larger increases in Chinese import competition in the 2000s were more likely to express conservative political beliefs in the second time period relative to the first time period. Column (4) further allows that ideology can change as a function of a CZ's initial manufacturing employment share and occupational composition, while column (5) allows for shifts in ideology related to counties' party preferences in the 2000 presidential election. The magnitude of the coefficient estimate in the final model of column (5) indicates that if we compare CZs at the $75^{\text {th }}$ and $25^{\text {th }}$ percentiles of trade exposure, the Pew ideology score would have increased by $0.65(0.57 \times 1.14)$ points, or one more right-leaning answer for every three survey respondents, between 2004 and 2014/2015 in the more-trade-exposed CZ relative to the less-trade-exposed CZ. ${ }^{28}$ These results constitute our first evidence that greater trade exposure affects political beliefs, on net shifting political outcomes in favor of conservative positions.

Table 2 suggests that the rightward shift in political beliefs over the 2000s was stronger among non-Hispanic whites than among other racial and ethnic groups. In subsequent columns of Table 2, we split the sample by racial and ethnic identity, with results for non-Hispanic-white participants appearing in column (6) and results for non-white participants shown in column (7). While the interaction between trade exposure and the second-period dummy is positive and precisely estimated for whites (t-value of 3.3), it is negative and imprecisely estimated for racial and ethnic minorities. These findings, showing an impact of trade shocks on political beliefs, are estimated on a relatively small set of Pew survey datasets. Our subsequent analysis examines changes in the composition of elected representatives. This allows us to detect changes in the political preferences of the full American electorate, as captured by election outcomes.

\subsection{Impact of Trade Shocks on Congressional Electoral Outcomes}

We now turn to our core results on equation (3) for electoral outcomes in congressional districts over the period 2002 to 2010, using county-by-congressional-district cells as units of analysis. As in the previous analysis of political beliefs, our regression models control for initial political conditions, the sectoral and occupation mix of local labor markets, and demographic composition. The controls for initial political conditions include the vote share of the winning party in 2002, a dummy for whether the winning candidate ran unopposed in 2002, and the Nominate score of the winning candidate in 2002, each interacted with a dummy for whether a GOP legislator won the 2002 election. The controls for initial economic conditions comprise the share of manufacturing in CZ employment, and

\footnotetext{
${ }^{28}$ The interquartile range of import exposure over 2004 to 2014 is 0.57 (Appendix Table A5), and an increase in the ideology score of 0.65 corresponds to one in every three respondents changing an answer from the left-leaning position (-1 point of ideology score) to the right-leaning position $(+1$ point $)$.
} 
the routine-task-intensity index and offshorability index for CZ occupations; demographic controls include county population shares for nine age and four racial groups, and the shares of the county population that are female, college educated, foreign born, and Hispanic. Each of these variables is measured in 2000. If a congressional district spans multiple CZs, the weighting structure produces averages across CZs, where weights are based on initial county population shares in the district. Standard errors are two-way clustered on the CZ and the congressional district. We estimate (3) using two-stage least squares, with the import-exposure variable instrumented by changes in Chinese imports to other non-U.S. high-income countries as in (2).

\subsubsection{Preliminary Analysis of Vote Shares, Turnover and Competitiveness}

Given the voluminous literature on the impact of economic conditions on incumbency, we begin by testing whether trade exposure attenuates the electoral advantage of the party initially in control of a congressional district. In column (A1) of Table 3, we measure incumbency as the change in the county-district vote share between 2002 and 2010 for the party that held the district in the initial year. ${ }^{29}$ There is a negative and precisely estimated impact of trade exposure on vote shares for the party initially in power. The coefficient estimate of -7.05 (t-value of -2.63 ) indicates that when comparing congressional districts at the $75^{\text {th }}$ versus $25^{\text {th }}$ percentiles of trade exposure, the more-exposed district would have had a $3.5(-7.05 \times 0.49)$ percentage-point lower share of the 2010 vote going to the party that was in power in 2002, where the mean vote share of the winning party in 2010 was $62.1 \%$ and the mean 2002 - 2010 vote-share change was $-8.5 \%$. Congressional districts containing commuting zones subject to larger increases in import competition thus saw a diminution of support for the party initially in office. This finding is consistent with the well-known result that voters punish parties that preside during bad economic times (e.g., Fair, 1996).

If greater trade exposure reduces support for the incumbent party, does it tend to help one party more than the other? In columns (A2) and (A3) of Table 3, we estimate the impact of an increase in CZ import competition on the change in the county-district shares of the Republican Party and Democratic party two-party vote shares. These regressions indicate a null effect. ${ }^{30}$ That we find no impact on party vote shares despite the initial evidence for a relationship between import exposure and political beliefs in Table 2 may seem surprising at first. However, Figures 1 and A1 showed that during the period of study, electoral margins of victory narrowed as more politically extreme

\footnotetext{
${ }^{29}$ Appendix Table A6 provides an expanded set of regression results that sequentially add control variables.

${ }^{30}$ The Republican two-party vote share is the percentage of Republican votes in the total of Republican and Democrat votes. The Democrat two-party vote share is by construction equal to $100 \%$ minus the Republican twoparty vote share. We also find small and insignificant impacts of trade exposure on percentage changes in Republican and Democrat votes among all votes cast.
} 
candidates gained office, thus suggesting that party vote shares may not provide a strong metric for the political positions of elected candidates, which we will study in the next section below.

Table 3: Import Exposure and Congressional Election Outcomes 2002-2010. (Dependent Variables: Change in Percentage of Vote Obtained by 2002 Winning Party; Change in Percentage of Vote Obtained by Republican, Democrat, and Other Parties; $100 \times$ Change in Probability that 2010 Race is Unopposed, or Is Won by $>75 \%$ of Vote; Turnout in Opposed Races; Log Campaign Contributions)

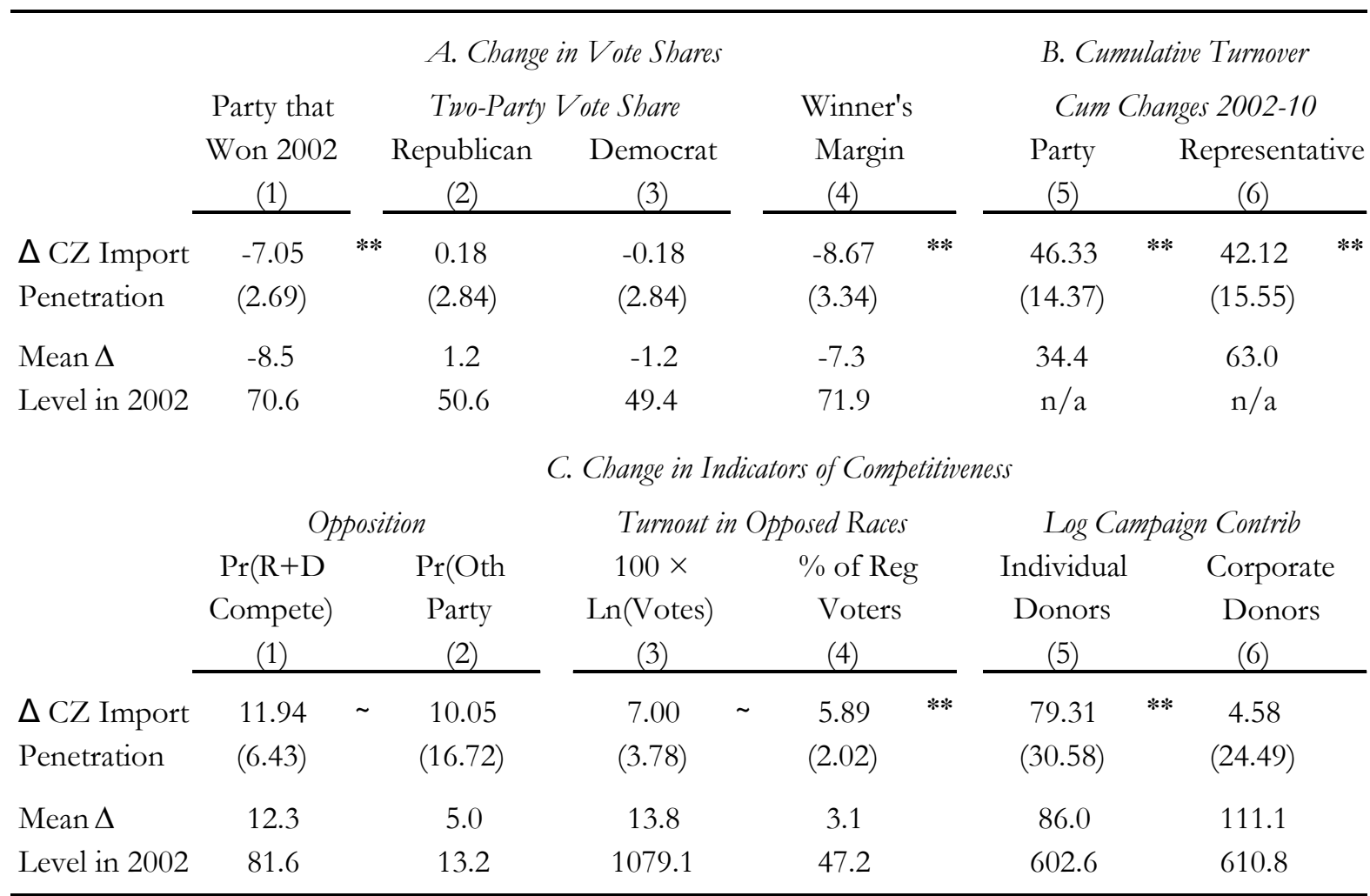

Notes: $\mathrm{N}=3,504$ County*District cells, except $\mathrm{N}=2,620$ in column $\mathrm{C} 3$ and $\mathrm{N}=2,363$ in column C4. All models includes a dummy for the election of a Republican candidate in 2002, the vote share of the winning party, a dummy for unopposed elections, the Nominate score of the 2002 election winner based on votes cast during the 2003-2005 Congressional period, where each of those variable is interacted with the dummy for a Republican election victory; the share of manufacturing in total employment (from the 2000 County Business Patterns data), as well as routine share and offshorability among occupations (based on Autor and Dorn (2013) and derived from 2000 Census data); the percentage of a county's population in 9 age and 4 racial groups and the population shares that are female, college-educated, foreign-born, and Hispanic; Census division dummies that allow for different time trends across the 9 geographical Census divisions. The two-party vote share in columns A2 and A3 measures a party's vote share as a fraction of the total of Republican and Democrat votes. Columns C3 and C4 measure turnout only for races in which candidates of several parties obtained votes, thus omitting unopposed races. Data on registered voters for column C4 is missing for the states of Georgia, Mississippi, North Dakota and Wisconsin. Columns C5 and C6 measure the log point change of one plus observed campaign contributions in $\$ 1,000$. Observations are weighted by a cell's share of total district population in 2000, and standard errors are two-way clustered on CZs and Congressional Districts. $\sim \mathrm{p} \leq 0.10,{ }^{*} \mathrm{p} \leq 0.05,{ }^{* *} \mathrm{p} \leq 0.01$.

The reduction in vote share for the initial incumbent party in column (A1) of Table 3 translates to an increased likelihood that trade-exposed districts change from one party to the other. The 
estimate in column (B5) implies that comparing congressional districts along the interquartile range of trade exposure, the more-exposed district would have a $22.70(46.33 \times 0.49)$ percentage-point greater likelihood of having experienced one more cumulative party change during the elections of 2004, 2006, 2008 and 2010. The turnover of representatives across or within parties increases by a similar magnitude (column B6).

As trade exposure induces more turnover of parties and representatives, it also heightens the intensity of political competition. This possibility is suggested by the in column A4 of Table 3, which indicates that over the sample period, trade exposure leads to elections that are decided by a narrower vote share margin. We examine the effect of trade exposure on the competitiveness of House elections further in the lower panel of Table 3. Columns (C1) and (C2) suggest that districts subject to greater import competition became more likely to have both major parties contest an election (which occurred in $81.6 \%$ of districts in 2002) and have third party candidates participate (13.2\% of districts in 2002), although both estimates are imprecise. In columns (C3) and (C4), we see that greater import competition produced an increase in votes cast in a county-district cell and in the percentage of registered voters who cast ballots in a district, where the first effect is significant at the $10 \%$ level and the second at the $1 \%$ level. And column (C5) shows that campaign contributions by individual donors grew by more in districts subject to larger increases in import competition, where the effect is precisely estimated. Comparing more and less trade-exposed districts, growth in $\log$ individual contributions was $39 \mathrm{log}$ points higher in more-trade-exposed locations. ${ }^{31}$ The same effect does not hold for contributions made by corporate entities, for which the estimated coefficient in column (C6) is close to zero. ${ }^{32}$ The positive impact of the import shock on turnout in the US Congressional elections contrasts with Guiso et al.'s (2017) observation of lower turnout in economically depressed areas of Europe (Guiso et al. 2017). As we discuss below, the results in columns (B3) through (B5) are consistent with the model of Glaeser et al. (2005) whereby politicians exploit wedge issues to catalyze turnout and campaign contributions among core supporters. ${ }^{33}$

Taken together, the results in Table 3 suggest that greater exposure to import competition results in more fiercely contested electoral contests and greater turnover of parties and representatives. ${ }^{34}$

\footnotetext{
${ }^{31}$ The mean log change in individual campaign contributions across districts over 2002 to 2010 was 86 log points.

${ }^{32}$ In 2002 , individual contributions averaged $48.0 \%$ of total contributions across districts. In the campaign-finance literature, individual contributions tend to account for a larger share of total contributions in closer political races (Ansolabehere et al., 2003), a finding with which our results are broadly consistent.

${ }^{33}$ Though Glaeser et al. (2005) do not consider individual versus corporate campaign contributions, their model of strategic extremism relies on voter inattentiveness. With this framing in mind, we would expect corporate campaign contributions to be less susceptible to this form of behavioral bias.

${ }^{34}$ This finding is consistent with the classic quiescence hypothesis in political science (Edelman, 1971), which views low voter turnout as indicative of voter satisfaction, and conversely, implies that rising voter dissatisfaction will spur turnout.
} 
More competitive elections could be the consequence of parties running more centrist candidates against each other who, because they compete for similar groups of voters, realize narrower electoral margins. However, the observed aggregate trends indicate that elected representatives actually became more politically extreme during the 2000s (Figure 1) despite winning more closely contested elections. The next set of results will demonstrate that the increase in trade exposure has contributed to this phenomenon-specifically, by increasing the share of legislators who hold more extreme positions, as revealed by their voting behavior on the floor of the House.

\subsubsection{Changes in Nominate Scores}

Table 4 presents our results for the impact of rising import competition from China on the partisan divide in Congress. In column (1), the dependent variable is 100 times the change in the Nominate score, which is increasing in the conservative positioning of a candidate based on her roll-call votes. This 2002-to-2010 change compares the voting behavior of legislators elected in 2002, whose roll-call votes are observed in the $108^{\text {th }}$ Congress (2003 to 2005), against the voting behavior of legislators elected in 2010, whose roll-call votes are observed in the $112^{\text {th }}$ Congress (2011 to 2013). Greater trade exposure predicts an increase in the Nominate score in a district, indicating that on net, districts subject to larger increases in import competition from China shifted more strongly toward legislators who were further to the right politically. Comparing districts at the $75^{\text {th }}$ and $25^{\text {th }}$ percentiles of trade exposure, the more-exposed district would have had an increase in the Nominate score that is 0.18 standard deviations higher. ${ }^{35}$ From Table 4, we see that the trade-induced shift in favor of more conservative legislators did not arise because GOP candidates generally receive higher vote shares. It resulted, instead, from the election of more conservative representatives, and is consistent with the rightward shift in political beliefs of Pew survey respondents in trade-exposed locations. ${ }^{36}$

The net positive impact of trade exposure on the Nominate score could either reflect a conservative shift among both Democratic and Republican representatives - with Democrats moving closer to the center and Republicans moving further to the right - or it could reflect movements away from the center in both parties, with Republican shifts being larger than those among Democrats. We address gross changes in Nominate scores in column (2) of Table 4, in which the dependent variable is the change between 2002 and 2010 of 100 times the absolute value of the distance between a

\footnotetext{
${ }^{35}$ For 2002 (the $108^{\text {th }}$ Congress), the standard deviation of $100 \times$ Nominate score is 49 , and the estimated interquartile effect (based on an interquartile range of exposure of 0.49$)$ is thus $(0.49 \times 18.13) / 49=0.18$.

${ }^{36}$ The magnitude of the trade-induced shift to the right is remarkably similar among elected representatives and in the general population. Comparing across the interquartile range of exposure, the more exposed district elected a representative with a 0.18 standard deviation higher Nominate score, whereas the Pew ideology score increased by $(0.57 \times 1.14) / 4.07=0.16$ standard deviations (using a coefficient of 1.14 from column (5) of Table 2 , an interquartile range of 0.57 for the corresponding trade shock, and a standard deviation of 4.07 for the Pew ideology score in 2004).
} 
legislator's Nominate score and the political center, which we take to be zero. ${ }^{37}$ Under this metric, a one-unit shift to the right in the Nominate score is accorded the same value as a one-unit shift to the left. Column (2) reveals that greater trade exposure led to a large and precisely estimated move away from the political center. Comparing districts at the $75^{\text {th }}$ versus $25^{\text {th }}$ percentile of trade exposure, the more-exposed district would have seen a relative increase of $0.27(0.49 \times 9.93 / 18)$ standard deviations in its distance from the political center. ${ }^{38}$

Table 4: Import Exposure and Change in Ideological Position of Election Winner 2002-2010. (Dependent Variables: $100 \times$ Change Nominate or Absolute Nominate Score of Winner)

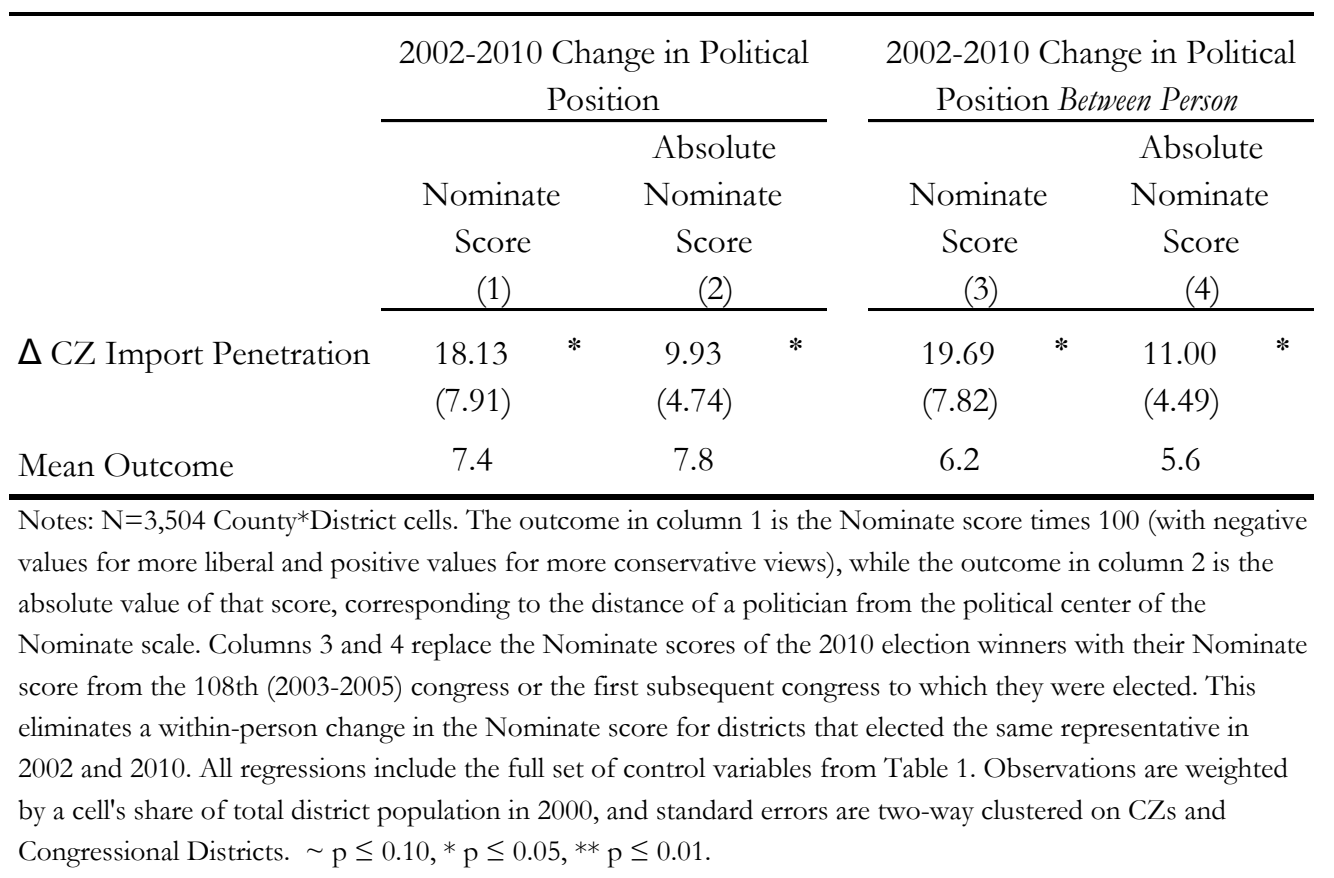

We next verify that, consistent with Lee et al. (2004), the induced change in Nominate scores seen in columns (1) and (2) of Table 4 resulted from turnover in legislators rather than from changes in the behavior of incumbents. Columns (3) and (4) redefine the dependent variables based on the difference in political positions between a district's representatives in 2002 and 2010, where each legislator's Nominate score for 2010 is replaced by the Nominate score observed in the first Congress in which she served during the 2002 to 2010 window. The columns (3) and (4) regressions thus capture the impact of trade exposure on the between-legislator (extensive margin) change in Nominate scores, as the outcome variable will have a value of zero for the $52 \%$ of districts in our sample that elected the same representative in both 2002 and 2010. The coefficients in the columns

\footnotetext{
${ }^{37}$ As noted above, the mean Nominate score over all 113 Congresses is very close to zero.

${ }^{38}$ For 2002, the standard deviation of 100 times the absolute value of distance from the political center (i.e., the absolute value of the Nominate score) is 18 .
} 
(3) and (4) regressions - the between-legislator effect - are very similar to those in the corresponding regressions of columns (1) and (2), which capture the between-plus-within-legislator effect. Thus, changes in the Nominate score stemmed primarily from the election of new conservative and liberal legislators, rather than from movements in voting away from the center by incumbents.

Table A7 explores the nature of these shifts in greater detail by documenting how Nominate scores change within districts as representatives are variously reelected, replaced with same-party representatives, or displaced by members of the opposing party. While over the 2002 to 2010 period, 30 House seats shift from a Democratic to a Republican legislator and 22 seats change hands in the other direction (panel A), these numbers are dwarfed by within-party transitions. There are 42 seats that go from one Democrat to another and 104 seats that go from one Republican to another. ${ }^{39}$ Unsurprisingly, when a House seat changes party hands, the Nominate score of the officeholder swings sharply, as seen in panel B of Table A7, averaging +94.8 points for Democrat-to-Republican party changes, and -72.5 points for Republican-to-Democrat party changes. Republican-to-Republican swaps are also associated with substantial rightward movements in Nominate scores, averaging +14.9 points, while Democrat-to-Democrat swaps are associated with comparatively modest leftward movements, averaging -2.9 points. Among officeholders of either party who persist between 2002 and 2010, there is a small change in observed ideology, though there is noticeably more rightward drift among Republican incumbents (+6.0 points) than leftward drift among Democratic incumbents (-1.5 points). Between 2002 and 2010, the average Nominate score change across the districts in our sample was +7.4. As shown in panel C of Table A7, this sizable rightward shift resulted primarily from a net increase in the number of seats held by Republicans (contributing 3.0 points) and the replacement of Republicans elected in 2002 with other Republican politicians who were more conservative on average (contributing 3.7 points). ${ }^{40}$

\footnotetext{
${ }^{39}$ Within-party transitions in legislators over 2002 to 2010 are primarily not the result of intra-party challenges, which are rare. Of the 435 representatives elected to the House in 2002, only 1 percent had lost office cumulatively due to a primary election defeat by 2010. More common is a GOP-to-GOP transition to result from the 2002 incumbent retiring or losing a later election to a Democrat, with a fellow Republican winning the seat back subsequently.

${ }^{40}$ The contribution of each margin to the total is simply the fraction of districts falling into each category (panel A) multiplied by the mean change in the nominate score conditional on each outcome occurring. For example, Democratto-Republican transitions, which occur in 30 of 416 districts in our sample and are associated with a +94.75 swing in the Nominate score contribute $6.83=94.75 \times(30 / 416)$ points to the mean Nominate score change between 2002 and 2010 of 7.39 (obtained by summing the entries in columns 2 through 7 of panel C). In an earlier version of this paper, we examined the impact of trade exposure on turnover of legislators within and between parties. See Autor, Dorn, Hanson, and Majlesi (2016, Table 4).
} 


\subsubsection{The Removal of Congressional Moderates}

The movement away from the political center seen in Table 4 reflects the much-discussed demise of congressional moderates (e.g., Layman et al., 2006). Table 5 examines the fortunes of centrists directly. The dependent variable in column (1) is the 2002-2010 change in an indicator for whether a "moderate" candidate is elected. We define a moderate as a legislator whose Nominate score falls between the $20^{\text {th }}$ and $80^{\text {th }}$ percentiles of Nominate scores in the $107^{\text {th }}$ Congress (2001-2003), which immediately precedes our sample period. ${ }^{41}$ Districts subject to larger increases in import competition from China were substantially less likely to elect a moderate legislator, an effect that is statistically significant ( $\mathrm{t}$-value of -2.69). Comparing more and less trade-exposed districts along the interquartile range, the more-exposed district would have become 17.6 percentage points less likely to have a centrist in power between 2002 and 2010. To put this magnitude in context, over the 2002 to 2010 time period, the fraction of "moderates" in the House declined from $56.8 \%$ to $37.1 \%$.

Table 5: Import Exposure and Change in Ideological Position of Election Winner 2002-2010. (Dependent Variables: $100 \times$ Change in Indicators for Election of Politician by Party and Political Position)

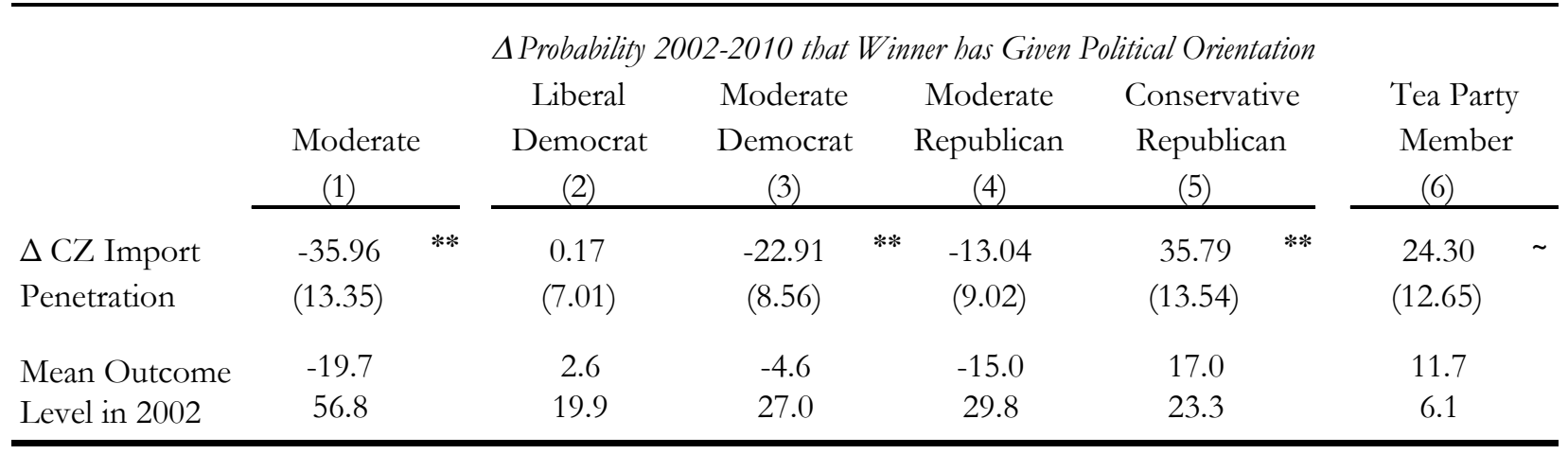

Notes: N=3,504 County*District cells."Liberal Democrats", "Moderates" and "Conservative Republicans" are defined as politicians whose Nominate scores would respectively put them into the bottom quintile, middle three quintiles, or top quintile of the Nominate score in the 107th (2001-2003) congress that preceeds the outcome period. A Tea Party Member is defined as a representative who was a member of the Tea Party or Liberty Caucus during the 112th (2011-2013) Congress. These two caucuses which are often associated with the Tea Party movement were first established in 2010 and 2011, respectively. All regressions include the full set of control variables from Table 3. Observations are weighted by a cell's share of total district population in 2000, and standard errors are two-way clustered on CZs and Congressional Districts. $\sim \mathrm{p} \leq 0.10,{ }^{*} \mathrm{p} \leq 0.05,{ }^{* *} \mathrm{p} \leq 0.01$.

Subsequent columns of Table 5 examine how trade shocks reallocate House seats according to party and ideology. We examine the change in the likelihood of a district electing a legislator whose

\footnotetext{
${ }^{41}$ Over all 113 congresses, the 20 th and 80 th percentile of Nominate scores (multiplied by 100) are -35.3 to +38.6 . For the $107^{\text {th }}$ Congress (2001-2003), it is -38.9 to +59.0 , indicating that many right-of-center legislators we are calling moderate would be decidedly conservative by historical standards. We examine below the robustness of our results to an alternative definition of moderate affiliation based on cardinal values of the Nominate score.
} 
voting record positions her as a liberal Democrat (column 2), a moderate Democrat (column 3), a moderate Republican (column 4), or a conservative Republican (column 5). In each regression, the dependent variable is the change over 2002 to 2010 in an indicator for whether a legislator of a particular type is elected. A liberal is a legislator whose Nominate score falls is the $20^{\text {th }}$ percentile for the $107^{\text {th }}$ Congress of 2001 to 2003, a moderate continues to indicate a legislator whose Nominate score is in the $20^{\text {th }}$ to 80 th percentile range of the $107^{\text {th }}$ Congress, and a conservative is a legislator whose Nominate score is above the $80^{\text {th }}$ percentile for the $107^{\text {th }}$ Congress. Because the categories in columns (2) to (5) are exhaustive and mutually exclusive, the coefficients sum to zero across columns and therefore indicate how trade exposure changes the ideological composition of Congress.

Districts subject to greater import competition became substantially less likely to elect a moderate Democrat and substantially more likely to elect a conservative Republican, with both of these effects precisely estimated ( $\mathrm{t}$-values of -2.68 and 2.64, respectively). A more versus less trade-exposed district would have become $11.2(-22.91 \times 0.49)$ percentage points less likely to have a moderate Democrat in power and $17.5(35.79 \times 0.49)$ percentage points more likely to be represented by a GOP conservative. Although a substantial fraction of the gains accruing to right-wing Republicans came at the expense of centrist Democrats, the rightward shift was not monotone. Trade exposure reduced the electoral success of moderate Democrats but had no measurable effect on the prospects of liberal Democrats. ${ }^{42}$ Conversely, gains among GOP conservatives in trade-exposed districts were accompanied by large, albeit imprecisely estimated, losses among GOP moderates.

The regression in column (6) of Table 5 tests additionally whether the trade shock affected the likelihood that a district elects a member who was or became affiliated with the Tea Party Caucus or the Liberty Caucus. These organizations, founded in 2010 and 2011, were the first congressional caucuses that have been characterized as being part of the Tea Party movement (Parker and Barreto, 2013). Tea Party membership thus provides us with an alternative outcome measure that captures the success of right-wing Republicans without relying on Nominate scores. ${ }^{43}$ Consistent with the column (5) results for GOP conservatives, the column (6) estimate indicates that trade exposure raised the probability of the election of a Tea Party member to office, with an effect size of 11.9 $(24.30 \times 0.49)$ percentage points in a more versus less trade-exposed district $(t=1.92)$.

The specification utilized in Table 5 has as the dependent variable the change in an electoral

\footnotetext{
${ }^{42}$ The fraction of districts represented by liberal Democrats increased from $19.9 \%$ in 2002 to $22.5 \%$ in 2010 .

${ }^{43}$ The average Nominate score of a Tea Party member in the 112th Congress was 78, which also equals the average score for all legislators who we classified as conservative Republicans in Table 5. Members of the Tea Party and Liberty Caucuses made up over $40 \%$ of the conservative Republicans elected in 2010, though it is certainly possible that the effective support of the Tea Party extends beyond the formal membership of these caucuses. The Tea Party movement in Congress remains fluid. Although the Tea Party Caucus is now largely inactive, the Liberty Caucus remains active and the more recently formed House Freedom Caucus has grown equal in size (DeSilver, 2015).
} 
outcome for a congressional district, with controls that include the initial Nominate score and its interaction with the party initially in power. ${ }^{44}$ We could alternatively specify the dependent variable as the 2010 outcome, rather than the change in outcome, as a function of initial conditions. Similarly, we could potentially control for the initial level of the Nominate score in a variety of ways that differ from our linear-in-party primary specification. In Table A8, we examine the sensitivity of the results in Table 5 to the choice of specification.

The first panel of Table A8 reports regressions using the first difference in the outcome measure as the dependent variable (our baseline approach), whereas panel B reports regressions using the 2010 electoral result as the outcome. We also vary specifications according to whether we exclude the initial Nominate score from the control vector, include the initial score or its quadratic without interaction with the party initially in power, include the initial Nominate score interacted with the party initially in power (the baseline specification), or include the interaction of the party initially in power with the quadratic of the Nominate score or with four bin-size dummies for the Nominate score. These alternative specifications allow for varying assumptions regarding how initial conditions affect later outcomes and the distribution of the error term. In all specifications, we continue to find a strong and significant negative impact of trade exposure on the likelihood of a moderate Democrat being elected in a district, and a more modest and statistically insignificant negative effect on the election success of moderate Republicans. The coefficient estimates for conservative Republicans and liberal Democrats are consistently positive, and are always significant for the former outcome while being marginally significant in some specifications for the latter. As a further sensitivity test, Table A9 re-estimates these models while classifying politicians' ideological positions based on cardinal values of Nominate scores rather than percentile rankings in the empirical distribution. ${ }^{45}$ The results are nearly identical to those in Table 5, underscoring the robust impact of import competition on political polarization.

We further explore the timing of shifts in legislator ideology within the 2002 to 2010 period. Panel (a) of Appendix Figure A3 plots coefficient estimates and 95\% confidence intervals from regressions that relate the change in legislator ideology to the 2002-2010 import shock for each of the time intervals 2002-2004, 2002-2006, 2002-2008 and 2002-2010 (with the regressions for the 2002-2010 outcomes corresponding to the estimates tabulated in columns (2) to (5) of Table 5). The figure indicates that seat losses of moderate Republicans in trade-exposed districts were concentrated in

\footnotetext{
${ }^{44}$ Since the initial Nominate score is used to categorize the ideological affiliation of the 2002 legislator, the 2002 Nominate score features in the construction of both the left and right-hand side variables.

${ }^{45}$ Table A9 classifies as moderates all legislators whose Nominate score is between -50 and +50 on the -100 to +100 scale. Under this alternative classification, most Democrats would be considered moderate while most Republicans would be considered non-moderate.
} 
the 2008 election, which concurred with the transition of the presidency from a Republican to a Democrat president (Bush to Obama). The negative impact of trade exposure on the election probability of moderate Democrats does not appear until the 2010 mid-term election which resulted in a large overall seat loss for Democrats. Similarly, the large positive impact of the import shock on the electoral success of conservative Republicans is largely due to the 2008 and 2010 elections. To assist the interpretation of these findings, panel (b) of Appendix Figure A3 provides a corresponding disaggregation over time for the trade-induced cumulative changes in parties and representatives that we reported in Table 3 above. The continuously increasing magnitude of the regression coefficients indicates that import-competing districts faced an elevated probability of changing to a different party and representative in any of the elections between 2004 and 2010. The combined 2008 and 2010 elections however account for nearly $80 \%$ of all party and representative changes, with the largest turnover effects accruing in the 2010 election. Since changes in Nominate scores occur almost exclusively due to the replacement of representatives rather than within-person changes in ideology over time (as shown in Table 4 and Appendix Table A7), we do not observe large trade-induced shifts in legislators' political positions until the 2008 and 2010 elections in which most of the trade-induced changes in parties and representative occur. These two elections coincide with a sharp increase in national unemployment due to the Great Recession, which may have increased voters' discontent with economic conditions and incumbent politicians especially in districts whose labor markets had already been in decline due to import competition.

\subsection{Impact of Trade Shocks on Presidential Elections}

Our findings indicate that trade exposure contributed to a net rightward shift in the ideology of elected legislators and a gain in House seats for the Republican party despite not having an impact on party vote shares. Because each Congressional district chooses among a disparate set of candidates, votes cast for a candidate with the same Nominate score in different districts are not necessarily votes cast in favor of a legislator with the same ideological position relative to local alternatives. Presidential elections by contrast provide a setting in which all localities simultaneously choose among the same candidates. Since the time-varying geographic structure of congressional districts is not relevant in this context, we can analyze county-level changes of party vote shares in presidential elections for a longer time period that is not constrained by re-districting. ${ }^{46}$

\footnotetext{
${ }^{46}$ Che et al. (2015) study how a greater expected stability of the tariff regime faced by Chinese imports in the United States following China's WTO accession in 2001 affected party vote shares during the 1998 to 2010 period. Since the policy change coincides with the intercensal congressional redistricting between the 2000 and 2002 elections, Che et al. (2015) aggregate congressional votes at the county level, where they find trade-related vote share gains for Democratic candidates. Our analysis of congressional elections, which uses county-by-district cells within intracensal intervals,
} 
Table 6: Exposure to Chinese Import Competition and Presidential Elections, 2000-2008 and 2000-2016, 2SLS Estimates. (Dependent Variable: Change in Percentage of Two-Party Vote Obtained by Republican Candidate, 2008 (McCain) or 2016 (Trump) vs 2000 (Bush))

\begin{tabular}{|c|c|c|c|c|c|c|c|c|c|c|c|c|}
\hline \multirow[b]{3}{*}{$\Delta$ CZ Import Penetration, 2000-2008 } & $(1)$ & & $(2)$ & & $(3)$ & & (4) & & (5) & & (6) & \\
\hline & \multicolumn{12}{|c|}{ A. $\Delta$ Net Republican Vote Share 2000-2008 } \\
\hline & $\begin{array}{c}0.53 \\
(0.52)\end{array}$ & & $\begin{array}{c}1.54 \\
(0.73)\end{array}$ & & $\begin{array}{c}1.60 \\
(0.73)\end{array}$ & & $\begin{array}{c}5.61 \\
(1.31)\end{array}$ & & $\begin{array}{c}3.61 \\
(1.05)\end{array}$ & & $\begin{array}{c}2.03 \\
(0.86)\end{array}$ & * \\
\hline \multirow[b]{2}{*}{$\Delta$ CZ Import Penetration, 2000-2008 } & \multicolumn{12}{|c|}{ B. $\Delta$ Net Republican Vote Share 2000-2016 } \\
\hline & $\begin{array}{c}2.75 \\
(0.98)\end{array}$ & $* *$ & $\begin{array}{c}3.86 \\
(1.48)\end{array}$ & $* *$ & $\begin{array}{c}3.68 \\
(1.40)\end{array}$ & $* *$ & $\begin{array}{c}4.48 \\
(1.69)\end{array}$ & & $\begin{array}{c}2.54 \\
(1.06)\end{array}$ & $*$ & $\begin{array}{c}2.18 \\
(0.95)\end{array}$ & \\
\hline Estimation Method & OLS & & 2SLS & & 2SLS & & 2SLS & & 2SLS & & 2SLS & \\
\hline F-statistic First Stage & & & 187.6 & $* *$ & 203.3 & $* *$ & 70.8 & $* *$ & 78.3 & $* *$ & 75.2 & \\
\hline \multicolumn{13}{|l|}{ Control V ariables } \\
\hline 2000 Election Controls & & & & & yes & & yes & & yes & & yes & \\
\hline 2000 Ind/Occ Controls & & & & & & & yes & & yes & & yes & \\
\hline 2000 Demography Controls & & & & & & & & & yes & & yes & \\
\hline Census Division Dummies & & & & & & & & & & & yes & \\
\hline
\end{tabular}

Notes: $\mathrm{N}=3,107$ counties. All regressions exclude AK and HI. The mean change in net Republican vote share is -3.50 (s.d. 5.69) between 2000 and 2008 and is -0.74 (s.d. 9.95) between 2000 and 2016. CZ import penetration increased by an average of 0.90 (s.d. 0.57 , interquartile range of 0.58 ) from 2000 to 2008 . Column 3 controls for the party that obtained the most votes in the county in the 2000 election, and the gross vote share of the winning party interacted with indicators for Republican and Democratic local majorities. Industry and occupation controls in column 4 are measured at the CZ level and comprise the share of manufacturing in total employment (from the 2000 County Business Patterns data), as well as routine share and offshorability among occupations (based on Autor and Dorn (2013) and derived from 2000 Census data). Demographic controls in column 5 comprise the percentage of a county's population in 9 age and 4 racial groups, as well as the population shares that are female, college-educated, foreign-born, and Hispanic. Census division dummies in column 6 allow for different time trends across the 9 geographical Census divisions. Observations are weighted by counties' total votes in the 2000 presidential election. $\sim \mathrm{p} \leq 0.10,{ }^{*} \mathrm{p} \leq 0.05,{ }^{* *} \mathrm{p} \leq 0.01$.

In Table 6, we estimate the impact of trade exposure on the change in the county-level GOP vote share between the 2000 and 2008 and the 2000 and 2016 presidential elections. These highly competitive elections bracket and extend forward the time period of our analysis of congressional elections. The three years considered - 2000, 2008, and 2016 - correspond to elections in which a two-term incumbent (Bill Clinton, George W. Bush, Barack Obama, respectively) was stepping down from office, and thus represent common positions in the political cycle. Our measure of trade has the advantage of avoiding the summation of votes across different congressional districts that overlap with the same county, and thus allows us to examine the party affiliation and ideological positions of the representatives that win elections in consistently defined congressional districts. The supplementary analysis of county-level party vote shares in presidential elections is more comparable to the setting in Che et al. (2015) but sidesteps the pitfalls posed by shifting intercensal congressional district boundaries. 
exposure is that used in (1), now defined for the period 2000 to 2008, while the instrumentation strategy follows that in section $3{ }^{47}$

The 2SLS estimates reported in Panel A of Table 6 find a positive and statistically significant impact of rising Chinese import competition on the share of votes going to the Republican presidential candidate between 2000 and 2008. The point estimate for the column (6) regression, which includes the full set of controls, implies that the Republican two-party vote share rose by more than one percentage point for an interquartile range increase in import penetration $(0.58 \times 2.03=1.18)$. Panel B indicates that the shift in party vote share caused by the import shock of 2000 to 2008 was quite persistent over time. Counties that had been more exposed to import competition during the Chinese import boom during this period continued to favor the Republican candidate in the 2016 election, and in the majority of specifications, the Republican gains are larger for the 2000-2016 period than for the 2000-2008 period. ${ }^{48}$ Thus, when we examine comparable electoral periods post 2000 - either intracensal congressional elections or presidential elections following two-term incumbent politicians - we see the same overall effect: greater trade exposure induces a net shift in favor of candidates on the right. We take these results to indicate that our use of intracensal changes in electoral outcomes for congressional districts provides an accurate characterization of the impact of trade shocks on U.S. political shifts in the 2000s.

\section{Mechanisms behind Polarization}

Our analysis of changes in political and electoral outcomes after 2000 reveals that greater regional exposure to import competition from China induced a net rightward shift in average political beliefs, diminished vote shares for the party initially in power, failed to realign vote shares in favor of either major political party, reduced the likelihood that a political moderate gains office, produced a net positive increase in the ideological conservativeness of elected representatives, and increased support for Republican presidential candidates. These shifts in legislator ideology were due to the election

\footnotetext{
${ }^{47}$ The sequentially added control variables closely follow the specification used for congressional elections; see notes to Table 6 for details.

${ }^{48}$ In a related research note (Autor, Dorn, Hanson and Majlesi 2017), we also find a significant positive impact on the change in GOP presidential county vote shares over 2000 to 2016 for a CZ-level trade shock that extends from 2000 to 2014, the last year for which we have trade data (where most of the increase in Chinese import penetration occurred by 2008). We calculate that a $50.0 \%$ ceteris paribus reduction in the China trade shock between $2000-14$ would have tipped the (narrow) voter majority in the states of Pennsylvania, Wisconsin, and Michigan, leading to an Electoral College victory for candidate Hillary Clinton, instead of a victory for Donald Trump. This notional exercise highlights the relevance of a trade-induced shift in party vote shares in presidential elections, which are more closely contested than most congressional elections. It however corresponds to a restrictive scenario where the China shock affects the 2016 U.S. presidential general election exclusively through its effect on the Republican two-party vote share. Our results above show that the China shock altered the ideological composition of the House prior to 2016, and those representatives' political activities may have subsequently contributed to the 2016 election outcome.
} 
of more extreme candidates, especially on the right, rather than changes in the voting patterns of incumbent politicians. Greater trade exposure also led to more competitive congressional races that had higher voter turnout and larger individual campaign contributions. In this section, we explore the mechanisms by which rising import competition may engender political polarization, and particularly a shift in favor of right-wing politicians.

\subsection{Initial Party Alignment, Belief Divergence, and Trade-Induced Polarization}

One mechanism by which economic shocks may foster polarization is through divergence in beliefs, a theoretical possibility explored formally by Dixit and Weibull (2007). Suppose that two groups (Democrats, Republicans) agree on objectives (to maximize the gains from government policy) but differ in their prior beliefs about the state of the world, one in which government intervention is helpful and one in which it is harmful. We term these world views as liberal and conservative for brevity. Groups with opposing world views may respond to the same signal - such as a change in their region's income level - by updating beliefs in opposite directions, with liberals becoming more convinced the world is one where intervention is productive and conservatives becoming similarly more convinced that intervention is counterproductive. While such polarization of beliefs will generally be transient, convergence of the two groups to common posterior beliefs need occur neither quickly nor monotonically (Acemoglu et al., 2015). A fact pattern that supports this hypothesis is that U.S. voters on the left and the right have become more hardened in their beliefs about the world, as seen in Table 1. Indicative of this ideological divergence, the gap between Republican identifiers/leaners and Democratic identifiers/leaners who agree with the statement "government regulation of business usually does more harm than good" grew from 7 percentage points in 2004 (45\% vs. $38 \%$ ) to 39 percentage points in 2014 (68\% vs. $29 \%) .{ }^{49}$

We test for party-based polarization in the spirit of Dixit and Weibull (2007) by contrasting the impact of trade shocks on initially Democratic versus initially Republican districts. Table 7 explores the heterogeneous effects of trade exposure on the ideology of elected representatives by reestimating the Table 5 regressions separately for districts that were in 2002 represented by a Democrat (panel A) or by a Republican (panel B). Column (2) shows that in both initially Democratic and initially Republican districts, trade exposure made the election of a moderate in 2010 much less probable, consistent with the results in Table 5. The negative impact of trade exposure on the likelihood of electing a moderate is particularly large in initially Democratic districts, where losses by moderate

\footnotetext{
${ }^{49}$ Similar divergences materialize on views regarding the wastefulness of government spending, the helpfulness of government assistance to the needy, and the consequences of immigration; there was no further divergence during the 2000s in views on military spending or the morality of homosexuality.
} 
Democrats accrued to both liberal Democrats and conservative Republicans. If we take two initially Democratic districts at opposing quartiles of trade exposure, the more-exposed district would have become $22.1(-45.12 \times 0.49)$ percentage points less likely to have a moderate Democrat in office in 2010, $7.5(15.30 \times 0.49)$ percentage points more likely to have a liberal Democrat in office, and 14.7 $(30.07 \times 0.49)$ percentage points more likely to have a conservative Republican in office. Although the trade-induced decline in moderate Democrat officeholders is statistically significant ( $t$-value of -2.42), the offsetting gains among liberal Democrats and conservative Republicans are not individually significant. Summing over these margins, trade shocks in initially Democratic districts predict a net rightward shift in the ideology of office holders. This is also seen in the estimated positive impact of trade exposure on the Nominate score (column 1) and on the probability of electing a Tea Party-affiliated representative (column 7), though neither effect is precisely estimated.

Table 7: Import Exposure and Change in Ideological Position of Election Winner 2002-2010. (Dependent Variables: $100 \times$ Change in Nominate Score of Winner, $100 \times$ Change in Indicators for Election of Politician by Party and Political Position.)

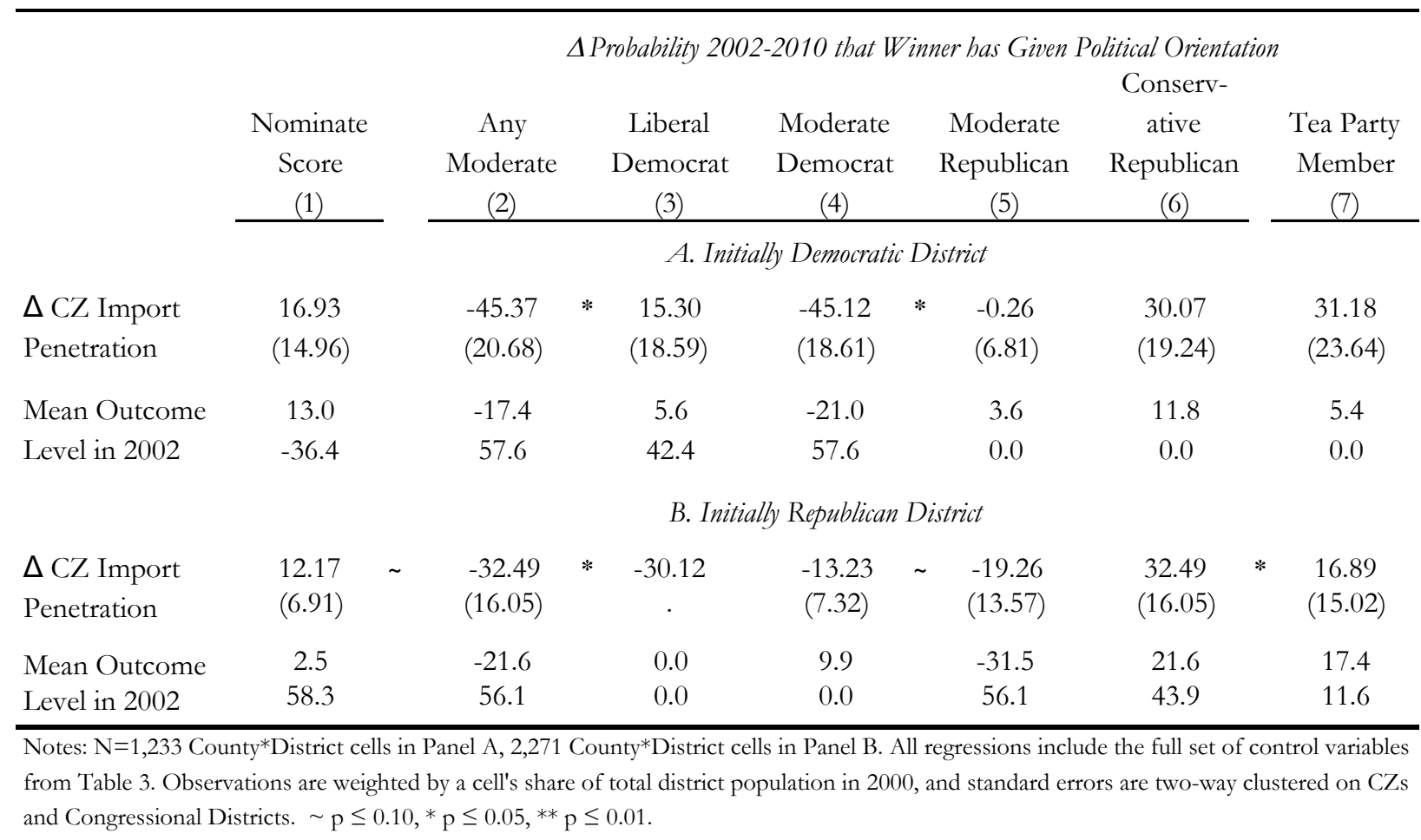

The shift away from moderates is the primary outcome that initially Democratic and initially Republican districts have in common. In initially Republican districts, the removal of centrists brought electoral gains for conservative Republicans exclusively. Comparing two initially Republican districts, one at the $75^{\text {th }}$ percentile of trade exposure and the other at the $25^{\text {th }}$ percentile, the results 
in columns (2) and (6) of panel B in Table 7 indicate that the more-exposed district would have become $15.9(32.49 \times 0.54)$ percentage points less likely to have a moderate in office (an outcome that occurred in $24.6 \%$ of initially Republican districts). Since there are no instances in which a liberal Democrat gained a seat in 2010 in a district that was Republican-held in 2002, the more-exposed district was in turn 15.9 percentage points more likely to have had a conservative Republican in office in 2010 (an outcome that occurred in $65.5 \%$ of initially Republican districts). Reflecting these electoral shifts, the average Nominate score rose in initially Republican districts, though this rise was actually slightly smaller than the corresponding increase in initially Democrat districts, reflecting the fact that the latter had much more headroom to rise.

One concern with the Table 7 estimates is that, because the samples are split according to the outcome of the 2002 House election, they may be partly driven by mean reversion. Table A10 addresses this issue by dividing counties across panels according to whether they voted majority Republican or majority Democrat in the 2000 presidential election. As this election was tightly contested between two candidates - with Democratic candidate Gore winning the popular vote and Republican candidate Bush winning the electoral-college vote -it provides a convenient metric of how votes in the pre-sample period separate along the Democratic-Republican divide. Using this pre-2002 sample split, the distinction between Republican-leaning and Democrat-leaning districts is at least equally stark. In trade-exposed locations that supported George W. Bush in the 2000 presidential election, the probability of either a Democratic or Republican moderate holding office fell steeply between 2002 and 2010, with a standardized effect size of $-23.7([-27.84-20.54] \times$ 0.49) percentage points. These losses among moderates accrued in their entirety to gains among conservative Republicans, with Nominate scores of office-holders in Bush-supporting districts rising sharply. In counties that supported Al Gore during the 2000 presidential election, trade exposure is estimated to have reduced the probability that a seat goes to a moderate Democrat between 2002 and 2010. Here, offsetting gains accrued roughly evenly to liberal Democrats, moderate Republicans, and conservative Republicans, though none of these effects is precisely estimated.

The results in Table 7 suggest that the consequence of an increase in import competition from China was a substantial rightward shift accompanied by increased political polarization across local labor markets. Initially GOP districts moved toward more conservative legislators; initially Democratic districts moved towards both more liberal and more conservative legislators. The primary casualty of these shifts was moderate Democrats, with moderate Republicans paying a smaller though non-negligible electoral toll. Although this evidence is roughly consistent with the Dixit and Weibull (2007) mechanism of divergent responses to common shocks based on initial political 
leanings, the increased support for conservative Republicans in initially Democratic districts (though insignificant) is not predicted by this model. Strictly speaking, one would have expected a sharper delineation in responses in trade shocks based on initial political alignment. This leads us to suspect that the ideological divergence explanation for polarization is incomplete.

\subsection{Racial Composition, Group Identity, and Trade-Induced Polarization}

An alternative mechanism by which trade shocks may foster polarization is by intensifying ingroup/out-group identification among voters. In influential work, Alesina et al. (1999) provide theoretical and empirical support for the idea that voters choose to supply fewer public goods when a significant fraction of tax revenues collected from one ethnic group is used to provide public goods shared with other ethnic groups. ${ }^{50}$ Experimental research also supports the finding that voters in an in-group object to their tax contributions being used to support individuals in out-groups (Habyarimana et al., 2007). If voters who feel economically disadvantaged by trade perceive greater competition for public resources, they may intensify their political attachment to their in-group in order to preserve their access to these resources.

There is substantial reason for voters to perceive trade shocks as increasing demand for government services. Autor et al. (2013) find that shocks to import competition increase uptake of government transfers. Comparing average-sized CZs at the $75^{\text {th }}$ versus $25^{\text {th }}$ percentiles of exposure between 2000 and 2007, their results predict a differential rise of more than $\$ 21$ million in annual public transfer payments (primarily healthcare, disability, and early retirement) in the more exposed CZ. Furthering competition for resources, trade shocks also adversely effect the local tax bases of impacted locations. Feler and Senses (2016) find that CZs exposed to the China trade shock (measured as in Autor et al., 2013) experienced reductions in business activity, housing prices, tax revenues and, ultimately, expenditure on social welfare programs and pubic housing. We hypothesize accordingly that trade shocks may catalyze anti-redistributionist sentiment (seen in the election of conservative Republicans) in majority white non-Hispanic locations where taxpayers may perceive themselves as transfer-payment donors, and pro-redistributionist sentiment (seen in election of liberal Democrats) in majority minority locations where taxpayers may perceive themselves as transfer-payment beneficiaries.

These resource-based competition explanations appear likely to be incomplete, however. Rightwing populist movements tend to arise during times of economic hardship and job insecurity (Mughan

\footnotetext{
${ }^{50}$ See Alesina and La Ferrara (2005b) for a discussion of national and international evidence on the link between ethnic fractionalization and support for public goods provision.
} 
et al., 2003), and their animus towards foreigners and minorities may reflect popular scapegoating of out-groups or political opportunism, whereby candidates channel public anger towards out-groups in pursuit of voter support. Glaeser et al. (2005) formalize this insight in a model where candidates for elected office engage in strategic extremism (e.g., inflaming wedge issues such as abortion) to increase turnout and campaign contributions among their core constituents. ${ }^{51}$ This mechanism can be mapped to our setting if we equate nativism and nationalism with wedge issues, which seems warranted given the policy platforms and iconography of political groups associated with the Tea Party movement (Parker and Barreto, 2013).

To assess whether trade heightens partisanship through strengthening of in-group attachment along demographic fault lines, we explore whether voter responses to trade shocks depend on the initial racial composition of their localities. Our use of race to identify in-groups and out-groups follows substantial literature in social psychology and political science (Hutchings and Valentino, 2004). Since the passage of the Civil Rights Act in 1964, voters have realigned politically along racial lines, with the Republican Party attracting stronger support from white voters and the base of the Democratic Party shifting toward ethnic and racial minorities (Valentino and Sears, 2005). As with the resource based explanation, the logic of the strategic opportunism model also leads us to predict that majority white non-Hispanic districts will tilt rightward in response to adverse economic pressures while majority minority districts will tilt leftward.

We test these predictions in Table 8. We split counties according to whether or not a majority of their voting-age residents were non-Hispanic whites according to Census 2000 enumeration data. The lion's share of U.S. county-district cells had a majority non-Hispanic white population: 3, 241 of 3,503 cells, corresponding to 350 of the 416 electoral districts (84.1\%) that are used in our analysis. ${ }^{52}$ This demographic split is, not surprisingly, correlated with the political affiliation of elected representatives: $59.2 \%$ of the population in majority white counties was represented by a moderate or conservative Republican in 2002; conversely, $79.0 \%$ of the population in minority-dominated areas was represented by a moderate or liberal Democrat in 2002. The ideology of elected representatives from these districts are not wholly distinct, however. In 2002, 24.7\% of representatives from majority white counties were moderate Democrats, and $9.6 \%$ of representatives from majority-minority districts were moderate Republicans, with another $11.4 \%$ conservative Republicans. Our regression model statistically accounts for these initial differences, as above, by taking county-district level first

\footnotetext{
${ }^{51}$ The key assumption is that a politician's supporters are more attentive to her message than are her opponent's supporters, so engaging in strategic extremism amplifies voter turnout more among supporters than among opponents.

${ }^{52}$ Our sample comprises 2, 892 counties, of which 2,719 are majority-white. Minority-dominated counties are more populous on average, so that the reported fraction of minority-dominated districts is larger than the fraction of minority-dominated counties.
} 
differences in each outcome variable between 2002 and 2010 - thus sweeping out a county-district effect - as well as by directly controlling for initial political orientation, economic conditions, and demographic characteristics.

Table 8: Import Exposure 2002-2010 and Ideological Position of 2010 Election Winner. (Dependent Variables: $100 \times$ Change in Nominate Score of Winner, $100 \times$ Change in Indicators for Election of Politician by Party and Political Position)

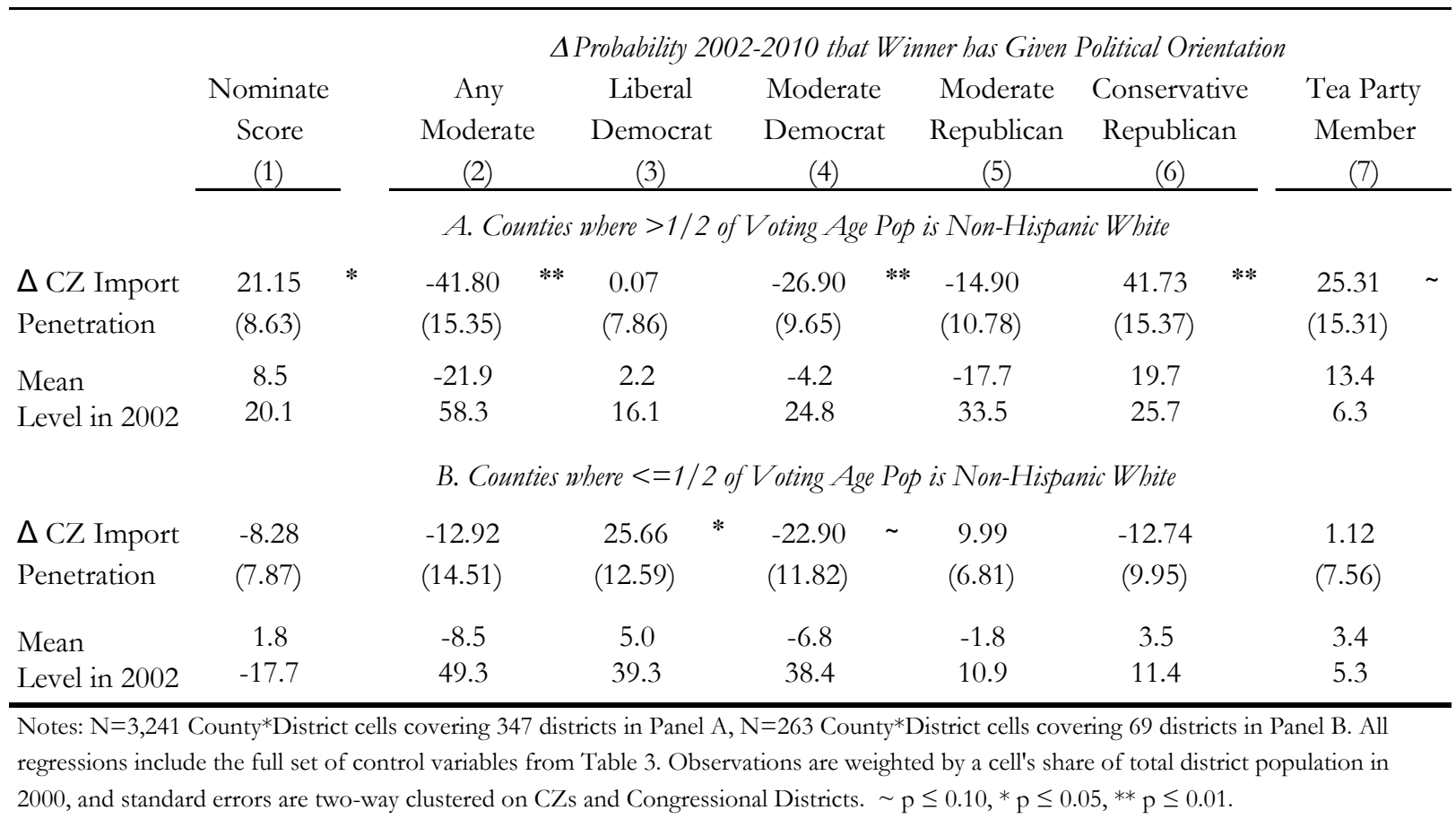

The upper panel of Table 8 shows that trade exposure catalyzed strong movements towards conservative Republicans between 2002 and 2010 in counties with majority non-Hispanic white populations. Scaling by the interquartile range of trade exposure, our point estimates imply that a more-versus-less-trade-exposed congressional district would on average have exhibited a 20.4 percentage point $(41.80 \times 0.49)$ increase in the probability that a conservative Republican takes office, with these gains coming at the expense of moderate Democrats ( -13.1 points) and moderate Republicans ( -7.3 points). The net effect of these movements was a large rightward shift in the Nominate score in trade-impacted counties that have majority non-Hispanic white populations, with a standardized effect size of a +10.4 point increment to the Nominate score ( $\mathrm{t}$-value of 2.45).

Focusing attention on the smaller subset of counties where less than half of the voting-age population is non-Hispanic white (panel B), we find a complementary pattern: liberal Democrats made strong gains in the probability of taking office, with a standardized effect size of 12.6 percentage 
points ( $\mathrm{t}$-value of 2.04). These gains came primarily at the expense of moderate Democrats, though conservative Republicans also lost ground. For political cleavages identified along either initial-party or racial lines, the story is comparable. Trade shocks favor non-centrist politicians, with conservatives winning at the expense of moderates in initially Republican or white-majority districts and liberals benefiting from moderates' demise in initially Democratic or majority-minority districts.

Our finding that counties diverge in their political responses to trade shocks based on their initial racial composition is consistent with the political economy literature documenting a connection between voter opposition to trade and identification with one's racial or ethnic group. Our results go beyond these regularities and show that economic shocks related to trade have a causal impact on political partisanship that separates according to race. Though we cannot cleanly differentiate the resource-based versus opportunism-based explanations for why trade shocks appear to amplify political cleavages along racial lines, our earlier findings that trade shocks raise both voter turnout and individual-level campaign contributions are consistent with the Glaeser et al. (2005) model in which opportunistic politicians deploy strategic extremism to spur participation among core supporters. While the Glaeser et al. model is silent on whether adverse economic shocks should heighten the prevalence of political opportunism, we find this possibility plausible. At its core, the strategicextremism model posits a behavioral anomaly where a candidate's core supporters are more attuned to the candidate's use of extremist rhetoric (e.g., "dog whistles") than are the candidate's opponents. Based on the evidence linking economic insecurity to populism, we suspect that economic discontent makes voters either more susceptible to the information asymmetry upon which strategic extremism relies, or more receptive to the messages deployed by politicians engaged in this strategy.

\subsection{Relative Exposure of White Men to Trade Shocks}

Recent literature on populism suggests that the increase in support for right-wing causes among whites is due in part to the relative and absolute decline in the economic status of white men, and of less-educated white men in particular (Inglehart and Norris, 2016; Gidron and Hall, 2017a,b). Men are also particularly strongly exposed to deteriorating local labor market conditions in tradeexposed regions, as they suffer more from a trade-induced decline of the manufacturing sector whose workforce comprises a higher fraction of males than the service sector (Autor, Dorn, and Hanson, 2017). This differential exposure may make white men especially susceptible to political appeals based on group identity, whether expressed as calls to protect their claim on public resources or as calls to arms to secure their communities against the threat posed by immigrants or minorities.

To identify trade shocks that particularly affect males, we subdivide the change in trade exposure 
in (1) into gender-specific components by harnessing longstanding differences in gender segregation across industries (Carrington and Troske, 1998). Following the approach in Autor, Dorn and Hanson (2017), we form these terms by multiplying each disaggregated industry component of the CZ import shock in (1) by the fraction of employment of that industry and CZ that was accounted for by males in 2000. We construct a corresponding import shock based on female employment, and we define an additional pair of exposure variables that separate white men from the complementary set of women and minorities (including both men and women). By construction, each pair of trade shocks (male vs. female; white male vs. female and minority) adds up to the aggregate import shock of our main analysis. ${ }^{53}$ By entering pairs of shocks into the regression analysis, we are able to determine whether trade shocks in the industries of men or white men have different impacts on election outcomes than trade shocks in the industries of other groups.

Table 9: Import Exposure 2002-2010 and Ideological Position of 2010 Election Winner. (Dependent Variables: $100 \times$ Change in Nominate Score of Winner, $100 \times$ Change in Indicators for Election of Politician by Party and Political Position)

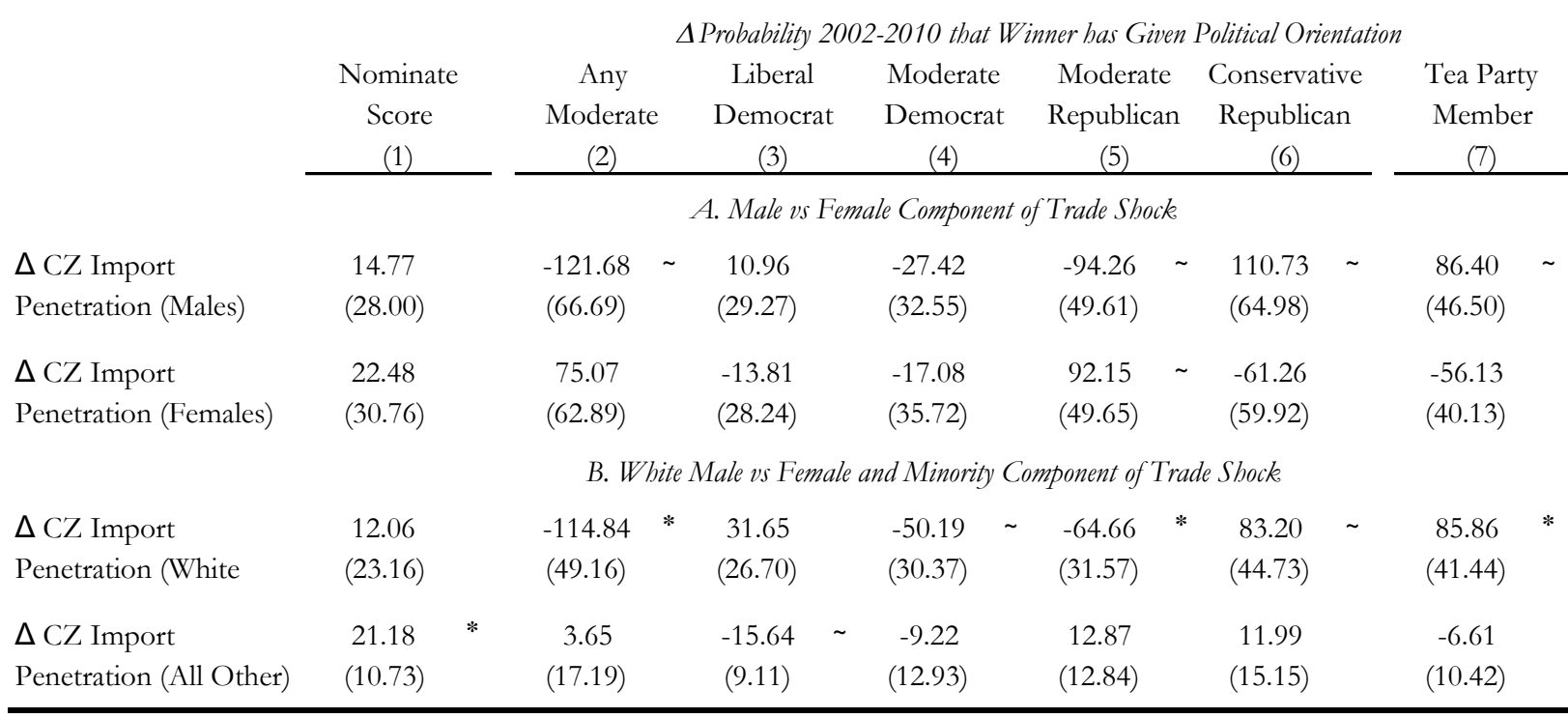

Notes: N=3,504 County*District cells. Following Autor, Dorn and Hanson (2017), the male (female) shock in panel A multiplies each industry component of CZ import exposure with the fraction of the industry's employment in that CZ that was male (female) in the year 2000 . Panels B and C implement corresponding splits for non-Hispanic whites vs. minorities, and white males vs. other population groups. All regressions include the full set of control variables from Table 3. Observations are weighted by a cell's share of total district population in 2000, and standard errors are two-way clustered on CZs and Congressional Districts. $\sim \mathrm{p} \leq 0.10,{ }^{*} \mathrm{p} \leq 0.05,{ }^{* *} \mathrm{p} \leq 0.01$.

Panel A of Table 9 suggests that trade exposure's contribution to the shift toward conservative Republicans between 2002 and 2010 can itself be attributed fully to shocks to industries with maleintensive employment, rather than shocks to industries with a strong representation of women.

\footnotetext{
${ }^{53}$ The mean (standard deviation) for the male and female import shock is $0.45(0.31)$ and $0.27(0.22)$, respectively, while the corresponding values for white men and other groups are $0.33(0.26)$ and $0.38(0.31)$.
} 
Whereas increased import competition in male-dominated industries reduced the likelihood that a moderate is elected (panel A, column 2) and increased the likelihood that a GOP conservative was elected (panel A, column 6), it had the opposite effects in female-dominated industries. Trade shocks to male industries are marginally significant in these two cases (t-values of -1.83 and 1.86, respectively), while the corresponding impacts of trade shocks to female industries are imprecisely estimated (t-values of 1.19 and -1.02 , respectively).

A clear quantitative distinction in the impact of trade shocks on electoral outcomes also appears when we separate industries according to their initial employment intensity of white men, shown in panel B of Table 9. Trade shocks to industries with sizable employment shares for white males engendered a large negative impact on the likelihood that a moderate is elected (panel B, column 2) and a large positive impact on the likelihood that a GOP conservative wins office (panel C, column 6), where the first effect is precisely estimated and the second is marginally significant (t-values of -2.34 and 1.86, respectively). By contrast, trade shocks to industries with belowmedian employment intensity of white men have quantitatively small and insignificant effects on election wins by moderates or conservatives ( $t$-values of 0.21 and 0.79 , respectively). Scaling by the interquartile range of trade exposure to white-male-intensive industries, a more-versus-less-tradeexposed congressional district would on average have exhibited a 20.0 percentage point $(83.20 \times 0.24)$ increase in the probability that a conservative Republican takes office, with these gains coming at the expense of moderate Democrats ( -12.1 points) and moderate Republicans (-15.6 points). ${ }^{54}$ There is also a positive but insignificant impact of greater trade exposure in white-male-dominated industries on the likelihood that a liberal Democrat is elected.

The results in Tables 8 and 9 resonate with the themes of recent literature on the political economy of right-wing populism, in which economic shocks to dominant population groups engender a political response that sharpens group identities and enhances support for conservative politicians. This pattern is evident in our finding that the impact of trade shocks on political polarization appears largely attributable to increases in foreign competition facing manufacturing industries that are intensive in the employment of non-Hispanic white males. By contrast, the component of the overall trade shock which affected women and nonwhites does not have similar electoral consequences. If instead our results were the byproduct of a secular rightward shift in politics, then any negative shock would favor conservatives, since it would reduce support for existing incumbents who on average would be more liberal than the challengers seeking to replace them. Our findings are inconsistent with this secular-shift hypothesis. It is not trade shocks in general that on net favor

\footnotetext{
${ }^{54}$ The interquartile range of the white-male specific subcomponent of the overall trade shock of 0.24 is, not surprisingly, smaller than the IQR for the overall trade shock.
} 
conservative politicians, but rather those that disproportionately affect white males.

\section{Impacts of Other Economic Shocks on Political Polarization}

As a final exercise, we explore whether other economic shocks have electoral consequences similar to trade exposure. We do not have a strong prior on the results of this comparison: on the one hand, adverse employment shocks stemming from international trade appear especially apropos to the nativist and anti-globalist sentiments that are common fodder for populist rhetoric; on the other hand, any shock that heightens perceived job insecurity may make the electorate more receptive to populist or nativist appeals. ${ }^{55}$ In Table 10, we augment the analysis in Table 7 by adding to our baseline specification two additional economic shock variables, a Bartik measure for the predicted change in CZ log employment based on national-industry employment changes, and a measure of the peak-to-trough log change in local housing prices during the post-2006 housing-market collapse (see Appendix sections A.1 and A.2). The first measure captures changes in national-industry economic conditions, and the second measure captures the differential exposure of local labor markets to the U.S. housing-market downturn. We also report coefficient estimates for the control variable of CZ employment in routine occupations in the year 2000, which is a predictor for computer adoption in local labor markets (Autor and Dorn, 2013).

Comparing first coefficients on the change in import penetration in Table 10 with those in Table 7, we see that results are substantially the same when we simultaneously account for these other economic shocks, which further confirms our findings on the political impacts of trade exposure.

We next examine the results in Table 10 on the electoral implications of exposure to the downturn in the U.S. housing market that accompanied the Great Recession. Our measure for the fall in house from the first quarter of 2007 to the fourth quarter of 2010 spans the two elections during which most of the turnover in congressional seats during our outcome period occurred. The coefficient pattern in Table 10 indicates that similar to trade shocks, greater housing-price reductions on net shift electoral outcomes against moderates and in favor of conservatives. These impacts however are not statistically significant, and of a smaller economic magnitude when the shocks are scaled by their interquartile range across CZs. A more adversely affected CZ at the $75^{\text {th }}$ percentile of house price declines (a 2007q1 to 2010q4 change of -24.6 log points) would face a 5.3-percentage-point larger reduction in the likelihood of electing a moderate and a similarly large increase in the likelihood of electing a conservative compared to one at the $25^{\text {th }}$ percentile of changes in housing prices (a 2007q1

\footnotetext{
${ }^{55}$ In analyzing presidential voting, Margalit (2011) finds that voters are more sensitive to local job loss due to foreign competition than to other factors.
} 
to $2010 \mathrm{q} 4$ change of $-2.7 \log$ points). ${ }^{56}$

Table 10: Alternative Labor Market Shocks and Change in Ideological Position of Election Winner 2002-2010. (Dependent Variables: $100 \times$ Change in Nominate Score of Winner, $100 \times$ Change in Indicators for Election of Politician by Party and Political Position.)

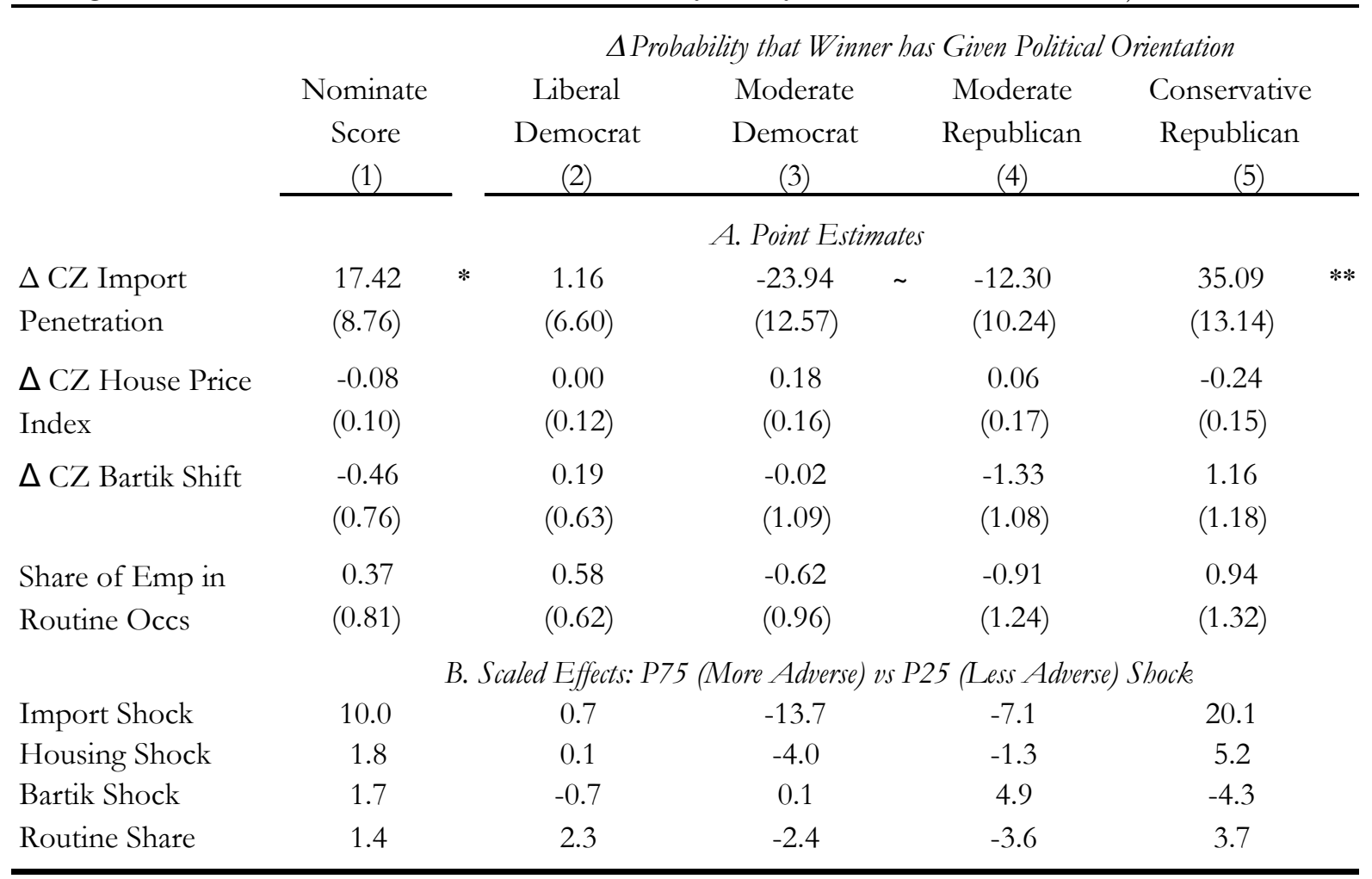

Notes: $\mathrm{N}=3,504$ County*District cells. The table reports regression coefficients, and scaled effects that compare the implied effects for CZs at the 75th percentile of adverse shocks (greater import competition, greater house price decline, more negative Bartik shift, greater start-of-period routine employment share) vs the 25th percentile. All regressions include the full set of control variables from Table 3. Observations are weighted by a cell's share of total district population in 2000, and standard errors are two-way clustered on CZs and Congressional Districts. $\sim \mathrm{p} \leq 0.10,{ }^{*} \mathrm{p} \leq 0.05,{ }^{* *} \mathrm{p} \leq 0.01$.

We also observe a similar result for the CZs that had a greater share of their overall employment in routine occupations in 2000, which provides a proxy for a CZ's susceptibility to technological change and automation (Autor and Dorn, 2013). More exposed locations have a reduced likelihood of electing moderates and an increased likelihood of electing more extreme politicians of either party. These impacts are again estimated with little statistical precision. Moving from a CZ at the $25^{\text {th }}$ percentile of routine employment to one at the $75^{\text {th }}$ percentile, the probability of electing a moderate falls by 6.0 percentage points, a magnitude that is similar to the interquartile-scaled effect of the house price decline but that falls well short of the impact of the trade shock, which is

\footnotetext{
${ }^{56}$ We also explored the correlation between the changes in electoral outcomes and the change in house prices over the full period of 2002 to 2010, which comprises both the housing boom and bust. The results are very similar to those in Table 10 and indicate that a $\mathrm{CZ}$ at the $75^{\text {th }}$ percentile of house price growth would be 5.4 percentage points more likely to elect a moderate than a CZ at the $25^{\text {th }}$ percentile. Feler and Senses (2016) show that changes in house prices are themselves partly determined by Chinese import competition, which dampened house price growth in more trade-exposed CZs.
} 
3.5 times larger. A generalized labor-demand shock, as predicted by a Bartik measure, also has no statistically significant effects, and has a coefficient pattern that suggests modest gains of moderate Republicans at the cost of conservative Republicans in locations with inward labor-demand shifts.

In sum, the results of Table 10 suggest that other concurrent economic shocks such as the downturn in the U.S. housing market or the automation of jobs may have contributed to the decline of congressional moderates and to gains for more extreme candidates especially on the right. The rapidly growing exposure to Chinese import competition however stands out as a shock that had particularly large and precisely estimated effects on heavily exposed local labor markets.

\section{Concluding Remarks}

The polarization of national politics has been one of the defining developments of American discourse of the last several decades. The coincidence of intensifying political partisanship and rising income inequality has led many to conjecture that economic changes are at least partly responsible for greater political divisiveness. Indeed, political actors have frequently suggested a connection between changes in the U.S. economy and the growing ideological divide in Congress. In the 2016 U.S. presidential campaign, candidates from both parties singled out China's rise as an international competitor as a principal cause of U.S. economic malaise. Yet, there is a paucity of evidence that substantiates a causal impact of specific economic shocks on political polarization.

Our contribution in this paper is to show that this vitriolic campaign rhetoric is indicative of underlying economic pressures that find voice in electoral contests. Growing import competition from China has contributed to a shift to the right in the political beliefs of U.S. adults as well as the near disappearance of moderate legislators in Congress, a shift in congressional voting toward ideological extremes, and net gains in the number of conservative GOP representatives. During the two most recent non-incumbent presidential elections, 2008 and 2016, trade shocks also differentially increased the vote share of the Republican candidate.

It may be unsurprising that negative impacts of trade on U.S. manufacturing have engendered an intense political response. Less expected is that the valence of this response depends nonmonotonically on the initial racial composition and political orientation of a congressional district and on the intensity of industry employment of non-Hispanic white males. In majority-white, rightleaning districts, the political beneficiaries of these economic forces are overwhelmingly Republicans from the far right, whereas majority-minority, left-leaning districts additionally, or entirely, experience shifts to the left end of the spectrum. The rightward shift is driven by trade shocks to industries 
that have traditionally employed white men in relatively large numbers and is largely unrelated to shocks to other industries. The paradox of converging popular beliefs about the source of economic challenges accompanied by diverging beliefs about appropriate political responses is consistent with theoretical models that connect economic adversity to in-group/out-group identification, as motivated by group-based resource competition or opportunistic use of political extremism.

Current expressions of voter anxiety substantiate our finding that the electoral consequences of trade are distinct from those of generalized changes in labor demand. What may distinguish trade in terms of its impact on political outcomes is that its disruptive effects are so concentrated demographically and geographically. The loss of manufacturing jobs has represented a major contraction in high-wage earning opportunities especially for less-educated males. Further, whereas exposure to technological change in the labor market has affected both wealthy cities populated by white-collar professionals and factory towns populated by blue-collar workers, rising import penetration from low-wage countries disproportionately bears on local labor markets that historically specialized in labor-intensive manufacturing (Autor et al., 2013b). The combination of these features enhances the salience of the labor-market impacts of trade and therefore their political resonance (Margalit, 2011). The connection between economic and political polarization may thus arise not from overarching secular changes in the U.S. economy that affect skill demands nationally, but rather from shocks whose disruptive force falls heavily on an identifiable set of voters who in turn respond with concentrated vehemence at the polls. 


\section{References}

Acemoglu, Daron, David Autor, David Dorn, Gordon H. Hanson, and Brendan Price. 2016. "Import Competition and the Great U.S. Employment Sag of the 2000s." Journal of Labor Economics, 34(S1): S141-S198.

Acemoglu, Daron, Victor Chernozhukov, and Muhamet Yildiz. 2015. "Fragility of Asymptotic Agreement Under Bayesian Learning." Theoretical Economics, 11, 187-225.

Alesina, Alberto, Reza Baqir, and William Easterly. 1999. "Public Goods And Ethnic Divisions." Quarterly Journal of Economics, 114(4): 1243-1284.

Alesina, Alberto, and Eliana La Ferrara. 2005a. "Preferences for Redistribution in the Land of Opportunities." Journal of Public Economics, 89: 897-931.

Alesina, Alberto, and Eliana La Ferrara. 2005b. "Ethnic Diversity and Economic Performance." Journal of Economic Literature, XLIII(Sept.): 762-800.

Algan, Yann, Sergei Guriev, Elias Papaioannou, and Evgenia Passari. 2017. "The European Trust Crisis and the Rise of Populism."

Ansolabehere, Stephen, John de Figueiredo, and James Snyder. 2003. "Why Is There So Little Money in U.S. Politics?" Journal of Economic Perspectives, 17(1): 105-130.

Autor, David H., and David Dorn. 2013. "The Growth of Low-Skill Service Jobs and the Polarization of the US Labor Market." American Economic Review, 103(5): 1553-97.

Autor, David H., David Dorn, and Gordon H. Hanson. 2013. "The China Syndrome: Local Labor Market Effects of Import Competition in the United States." American Economic Review 103(6): 2121-2168.

Autor, David H., David Dorn, and Gordon H. Hanson. 2013b. "The Geography of Trade and Technology Shocks in the United States." American Economic Review 103(3): 220-225.

Autor, David H., David Dorn, and Gordon H. Hanson. 2016. "The China Shock: Learning from Labor Market Adjustment to Large Changes in Trade." Annual Review of Economics, 8:205-40.

Autor, David H., David Dorn, and Gordon H. Hanson. 2017. "When Work Disappears: Manufacturing Decline and the Falling Marriage-Market Value of Men." NBER Working Paper 23173, February.

Autor, David H., David Dorn, Gordon H. Hanson, and Kaveh Majlesi. 2016. "A Note on the Effect of Rising Trade Exposure on the 2016 Presidential Election," Mimeo, MIT.

Autor, David H., David Dorn, Gordon H. Hanson, and Jae Song. 2014. "Trade Adjustment: Worker Level Evidence." Quarterly Journal of Economics 129(4): 1799-1860.

Bai, Xue, Kala Krishna and Hong Ma. 2015. "How You Export Matters: Export Mode, Learning and Productivity in China." NBER Working Paper No. 21164.

Bailey, Michael, and David W. Brady. 1998. "Heterogeneity and Representation: The Senate and Free Trade." American Journal of Political Science, 42(2): 524-544.

Baldwin, Robert E., and Christopher S. Magee. 2000. "Is Trade Policy for Sale? Congressional Voting on Recent Trade Bills." Public Choice, 105: 79-101.

Barber, Michael J. and Nolan McCarty. 2015. "Causes and Consequences of Polarization." In Persily, Nathaniel, ed., Solutions to Political Polarization in America. Cambridge University Press, pp. 19-53.

Bartik, Timothy J. 1991. "Who Benefits from State and Local Economic Development Policies?" W. E. Upjohn Institute for Employment Research.

Beaulieu, Eugene. 2002. "The Stolper-Samuelson Theorem Faces Congress." Review of International Economics, 10(2): 343-360.

Bernard, Andrew B., J. Bradford Jensen, and Peter K. Schott. 2006. "Survival of the Best Fit: 
Exposure to Low-Wage Countries and the (Uneven) Growth of U.S. Manufacturing Plants." Journal of International Economics 68(1): 219-237.

Bloom, Nicholas, Mirko Draca, and John Van Reenen. 2016. "Trade Induced Technical Change? The Impact of Chinese Imports on Innovation, IT and Productivity." Review of Economic Studies, 83(1): 87-117.

Bonica, Adam. 2013. "Database on Ideology, Money in Politics, and Elections: Public version 1.0" [Computer file]. Stanford, CA: Stanford University.

Brandt, Loren, Johannes Van Biesebroeck, and Yifan Zhang. 2012. "Creative Accounting or Creative Destruction? Firm-Level Productivity Growth in Chinese Manufacturing." Journal of Development Economics, 97(2): 339-351.

Burnside, Craig, Martin Eichenbaum, and Sergio Rebelo. 2013. "Understanding Booms and Busts in Housing Markets," Mimeo, Northwestern University.

Brunner, Eric, Stephen L. Ross, and Ebonya Washington. 2001. "Economics and Policy Preferences: Causal Evidence of the Impact of Economic Conditions on Support for Redistribution and Other Ballot Proposals." Review of Economics and Statistics, 93(3): 888-906.

Calvert, Randall, and John Ferejohn. 1983. "Coattail Voting in Recent Presidential Elections." American Political Science Review, 7: 407-419.

Carrington, William J. and Kenneth R. Troske. 1998. "Sex Segregation in U.S. Manufacturing." ILR Review, 51(3): 445-464.

Che, Yi, Yi Lu, Justin R. Pierce, Peter Schott, and Zhigang Tao. 2015. "Do Chinese Imports Influence American Politics?" Mimeo, Yale.

Colantone, Italo, and Piero Stanig. 2016a. "Global Competition and Brexit." BAFFI CAREFIN Centre Research Paper No. 2016-44, September.

Colantone, Italo, and Piero Stanig. 2016b. "The Trade Origins of Nationalist Protectionism: Import Competition and Voting Behavior in Western Europe." Mimeo, Bocconi University.

de Bromhead, Alain, Barry Eichengreen, and Kevin O'Rourke. 2013. "Political Extremism in the 1920s and 1930s: Do the German Lessons Generalize?" Journal of Economic History, 73(2): 371-406.

DellaVigna, Stefano and Ethan Kaplan. 2007. "The Fox News Effect: Media Bias and Voting." Quarterly Journal of Economics, 122: 1187-1234.

DeSilver, Drew. 2015. "What Is the House Freedom Caucus and Who's in It?" Pew Research Center.

Destler, Irving M. 2005. American Trade Politics, 4th Edition. Washington, DC: Institute for International Economics.

Diamond, Rebecca. 2016. "The Determinants and Welfare Implications of US Workers' Diverging Location Choices by Skill: 1980-2000." American Economic Review, 106(3): 479-524.

Dippel, Christian, Robert Gold, and Stephan Heblich. 2015. "Globalization and Its (Dis-) Content: Trade Shocks and Voting Behavior." NBER Working Paper No. 21812.

Dixit, Avinash K., and Jorgen W. Weibull. 2007. "Political Polarization." PNAS, 104(18): $7351-7356$.

Doherty, Carroll, Jocelyn Kiley, Alec Tyson, and Bridget Jameson. 2016. "Campaign Exposes Fissures over Issues Values and How Life and Changes in the U.S." Pew Research Center.

Dorn, David. 2009. "Essays on Inequality, Spatial Interaction, and the Demand for Skills." PhD dissertation 3613, University of St. Gallen.

Ebenstein, Avraham, Ann Harrison, Margaret McMillan and Shannon Phillips. 2014. "Estimating the Impact of Trade and Offshoring on American Workers Using the Current Population Survey." Review of Economics and Statistics, 96(3): 581-595. 
Edelman, Murray J. 1971. Politics as Symbolic Action; Mass Arousal and Quiescence. Chicago: Markham Pub. Co.

Erikson, Robert S. 1988. "The Puzzle of Midterm Loss." Journal of Politics, 50(4): 1011-1029.

Fair, Ray C. 1978. "The Effect of Economic Events on Votes for President." Review of Economics and Statistics, 60(2): 159-173.

Fair, Ray C. 1996. "Econometrics and Presidential Elections." Journal of Economic Perspectives, 10(3): 89-102.

Feigenbaum, James J., and Andrew B. Hall. 2015. "How Legislators Respond to Localized Economic Shocks: Evidence from Chinese Import Competition." Journal of Politics, forthcoming.

Feler, Leo, and Mine Z. Senses. 2016. "Trade Shocks and the Provision of Local Public Goods." Mimeo, Johns Hopkins University.

Fordham, Benjamin O., and Timothy J. McKeown. 2003. "Interest Groups and Congressional Voting on Trade Policy." International Organization, 57(3): 519-549.

Frank, Thomas H. 2004. What's the Matter with Kansas? New York: Henry Holt and Company.

Funke, Manuel, Moritz Schularick, and Christoph Trebesch. 2015. "Politics in the Slump: Polarization and Extremism after Financial Crises, 1870 - 2014." CEPR, Discussion Paper No. 10884.

Gelman, Andrew, David Park, Boris Shor, Joseph Bafumi, and Jeronimo Cortina. 2008. Red State, Blue State, Rich State, Poor State: Why Americans Vote the Way that They Do. Princeton University Press.

Gentzkow, Matthew. 2016. "Polarization in 2016." Mimeo, Stanford University.

Gentzkow, Matthew, Jesse M Shapiro, and Matt Taddy. 2016. "Measuring Polarization in HighDimensional Data: Method and Application to Congressional Speech." NBER Working Paper No. 22423.

Gidron, Noam and Peter A. Hall. Forthcoming. "The Politics of Social Status: Economic and Cultural Roots of the Populist Right." British Journal of Sociology.

Glaeser, Edward L., Joseph Gyourko, and Albert Saiz. 2008. "Housing Supply and Housing Bubbles." Journal of Urban Economics, 64(2): 198-217.

Glaeser, Edward L, Giacomo A.M. Ponzetto, and Jesse M Shapiro. 2005. "Strategic Extremism: Why Republicans and Democrats Divide On Religious Values." Quarterly Journal of Economics, 120 (4): 1283-1330.

Guiso, Luigi, Helios Herrera, Massimo Morelli, and Tommaso Sonno. 2017. "Demand and Supply of Populism." CEPR Working Paper no. 11871.

Habyarimana, James, Macartan Humphreys, Daniel N. Posner, and Jeremy M. Weinstein. 2007. "Why Does Ethnic Diversity Undermine Public Goods Provision?" American Political Science Review, 101(4): 709-725.

Hiscox, Michael J. 2002. "Commerce, coalitions, and factor mobility: Evidence from congressional votes on trade legislation." American Political Science Review, 96(3), 593-608.

Hsieh, Chang-Tai, and Ralph Ossa. 2015. "A Global View of Productivity Growth in China." NBER Working Paper No. 16778.

Hsieh, Chang-Tai, and Zheng Song. 2015. "Grasp the Large, Let Go of the Small: The Transformation of the State Sector in China." NBER Working Paper No. 21006.

Hutchings, Vincent L., and Nicholas A. Valentino. 2004. "The Centrality of Race in American Politics." Annual Review of Political Science, 7:383-408.

Inglehart, Ronald, and Pippa Norris. 2016. "Trump, Brexit, and the Rise of Populism: Economic Have-Nots and Cultural Backlash." HKS Faculty Research Working Paper Series RWP16-026.

Jensen, J. Bradford, Dennis P. Quinn, and Stephen Weymouth. 2016. "Winners and Losers in International Trade: The Effects on U.S. Presidential Voting." NBER Working Paper No. 21899. 
Johnson, Harry G. 1965. "A Theoretical Model of Economic Nationalism in New and Developing States." Political Science Quarterly, 80(2): 169-85.

Judis, John B. 2016. The Populist Explosion: How the Great Recession Transformed American and European Politics. Columbia Business Reports.

Katz, Lawrence F., and David Autor. 1999. "Changes in the Wage Structure and Earnings Inequality," in Orley Ashenfelter and David Card, eds., Handbook of Labor Economics, Vol. 3A, Amsterdam: Elsevier Science, 1463-1555.

Kleinberg, Katja B., and Benjamin O. Fordham. 2013. "The Domestic Politics of Trade and Conflict." International Studies Quarterly, 57: 605-619.

Kuk, Seungmin John, Deborah Seligsohn, and Jiakun Jack Zhang. 2015. "How Rising Import Competition Has Changed Congressional Voting towards China." Mimeo, UC San Diego.

Layman, Geoffrey C., Thomas M. Carsey, and Juliana Menasce Horowitz. 2006. "Party Polarization in American Politics: Characteristics, Causes, and Consequences." Annual Review of Political Science, 9: 83-110.

Levendusky, Matthew. 2009. The Partisan Sort: How Liberals Became Democrats and Conservatives Became Republicans. University of Chicago Press.

Levendusky, Matthew. 2013. How Partisan Media Polarize America. University of Chicago Press.

Levitt, Steven D., and Catherine D. Wolfram. 1997. "Decomposing the Sources of Incumbency Advantage in the U. S. House." Legislative Studies Quarterly, 22(1): 45-60.

Lewis-Beck, Michael S., and Mary Stegmaier. 2000. "Economic Determinants of Electoral Outcomes." Annual Review of Political Science, 3: 183-219.

Madestam, Andreas, Daniel Shoag, Stan Veuger, and David Yanagizawa-Drott. 2013. "Do Political Protests Matter? Evidence from the Tea Party Movement." Quarterly Journal of Economics, 128 (4): 1633-1685.

Malgouyres, Clement. 2014. "The Impact of Exposure to Low-Wage Country Competition on Votes for the Far-Right: Evidence from French Presidential Elections." Mimeo, European University Institute.

Mansfield, Edward, and Diana C. Mutz. 2009. "Support for free Trade: Self-interest, Sociotropic Politics, and Out-Group Anxiety." International Organization, 63(3): 425-57.

Mansfield, Edward, and Diana C. Mutz. 2013. "Us versus Them: Mass Attitudes toward Offshore Outsourcing." World Politics 65(4): 571-608.

Margalit, Yotam. 2011. "Costly Jobs: Trade-Related Layoffs, Government Compensation, and Voting in U.S. Elections." American Political Science Review, 105(1): 166-188.

McCarty, Nolan, Howard Rosenthal, and Keith T. Poole. 2006. Polarized America: The Dance of Ideology and Unequal Riches. MIT Press.

McCarty, Nolan, Howard Rosenthal, and Keith T. Poole. 2009. "Does Gerrymandering Cause Polarization?" American Journal of Political Science, 53(3): 666-680.

Mian, Atif, and Amir Sufi. 2009. "The Consequences of Mortgage Credit Expansion: Evidence from the U.S. Mortgage Default Crisis." Quarterly Journal of Economics, 124 (4): 1449-1496.

Mian, Atif, and Amir Sufi. 2011. "House Prices, Home Equity-Based Borrowing, and the U.S. Household Leverage Crisis." American Economic Review, 101(5): 2132-2156.

Mian, Atif, and Sufi, Amir. 2014. "What Explains the 2007-2009 Drop in Employment?" Econometrica, 82: 2197-2223.

Mian, Atif, Amir Sufi and Francesco Trebbi. 2010. "The Political Economy of the US Mortgage Default Crisis." American Economic Review, 100(5): 1967-98.

Mian, Atif, Amir Sufi and Francesco Trebbi. 2014. "Resolving Debt Overhang: Political Constraints in the Aftermath of Financial Crises." American Economic Journal: Macroeconomics, 6(2): 
$1-28$.

Mian, Atif, Amir Sufi, and Francesco Trebbi. 2015. "Foreclosures, House Prices, and the Real Economy." Journal of Finance, 70: 2587-2634.

Milner, Helen V., and Dustin H. Tingley. 2011. "Who supports global economic engagement? The sources of preferences in American foreign economic policy." International Organization, 65(1): 37-68.

Mughan, A., C. Bean., and I. McAllister. 2003. "Economic Globalization, Job Insecurity and the Populist Reaction." Electoral Studies, 22: 617-633.

Naughton, Barry. 2007. The Chinese Economy: Transitions and Growth. Cambridge, MA: MIT Press.

Palmer, Christopher. 2015. "Why Did So Many Subprime Borrowers Default during the Crisis: Loose Credit or Plummeting Prices?" Mimeo, UC Berkeley.

Parker, Christopher and Matt A. Barreto. 2013. Change They Can't Believe in: The Tea Party and Reactionary Politics in America. Princeton: Princeton University Press.

Peltzman, Sam. 1984. "Constituent Interest and Congressional Voting." Journal of Law and Economics, 27(1), April:181-210.

Pew Research Center. 2014. "Political Polarization in the American Public."

Pierce, Justin R., and Peter Schott. 2012. "A Concordance between Ten-digit U.S. Harmonized System Codes and SIC/NAICS Product Classes and Industries." Journal of Economic and Social Measurement, 37(1-2): 61-96.

Pierce, Justin R, and Peter K Schott. 2016. "The Surprisingly Swift Decline of U.S. Manufacturing Employment." American Economic Review, 106(7): 1632-1662.

Poole, Keith T., and Howard Rosenthal. 1985. "A Spatial Model for Legislative Roll Call Analysis." American Political Science Review, 29(2): 357-384.

Poole, Keith T., and Howard Rosenthal. 1991. "Patterns of Congressional Voting." American Journal of Political Science, 35(1): 228-278.

Poole, Keith T., and Howard Rosenthal. 1997. Congress: A Political-Economic History of Roll Call Voting. Oxford: Oxford University Press.

Poole, Keith T., and Howard Rosenthal. 2001. "D-Nominate after 10 Years: A Comparative Update to Congress: A Political-Economic History of Roll-Call Voting." Legislative Studies Quarterly, 26(1): 5-29.

Prior, Markus. 2013. "Media and Political Polarization." Annual Review of Political Science, 16: 101-127.

Ruggles, Steven, Katie Genadek, Ronald Goeken, Josiah Grover, and Matthew Sobek. Integrated Public Use Microdata Series: Version 6.0 [Machine-Readable Database]. Minneapolis: University of Minnesota.

Tyson, Alec, and Shiva Maniam. 2016. "Behind Trump's Victory: Divisions by Race, Gender, Education." Pew Research Center.

Tolbert, Charles M. and Molly Sizer. 1996. "U.S. Commuting Zones and Labor Market Areas. A 1990 Update." Economic Research Service Staff Paper No. 9614.

Valentino, and Sears. 2005. "Old Times Are Not Forgotten: Race and Partisan Realignment in the South." American Journal of Political Science, 49(3): 672-688.

Voorheis, John, Nolan McCarty, and Boris Shor. 2016. "Unequal Incomes, Ideology and Gridlock: How Rising Inequality Increases Political Polarization." Mimeo, University of Oregon.

Walker, W. Reed. 2013. "The Transitional Costs of Sectoral Reallocation: Evidence From the Clean Air Act and the Workforce." Quarterly Journal of Economics, 128(4): 1787-1835. 


\section{Appendix Figures and Tables}

\section{A.1 Bartik Shock for Commuting Zones}

To construct a measure of industry shocks to local labor markets, we use a Bartik (1991) measure,

$$
B_{i t}=\sum_{j} \frac{L_{i j t}}{L_{i t}} \frac{\Delta L_{j \tau}^{-i}}{L_{j t}^{-i}}
$$

where $L_{i j t} / L_{i t}$ is the share of industry $j$ in the employment of $\mathrm{CZ} i$ in $2000, \Delta L_{j \tau}^{-i} / L_{j t}^{-i}$ is the relative growth of employment in industry $j$ over 2000 to 2010 for all U.S. regions excluding CZ $i$, and $\tau$ again indicates the 2000 to 2010 time difference. ${ }^{57}$ Because regions differ in their industry specialization patterns and because employment rises and falls unevenly across industries over time, CZs are differentially exposed to national changes in U.S. industries' labor demand.

\section{A.2 Change in House Prices for Commuting Zones}

Our time period spans the Great Recession, which was triggered in part by the collapse of the U.S. housing market (Mian and Sufi, 2014). A commonly used metric for local-area exposure to the housing market collapse is the change in housing prices from the peak of the market in early 2007 to the market trough in early 2011 (e.g., Mian, Sufi, and Trebbi, 2015; Palmer, 2015). Following the literature, we use the Federal Housing Finance Agency housing price index on repeat sales at the zipcode level to construct the average log change in housing prices at the CZ level between 2007q1 and 2010q4. The last quarter of this period comprises the 2010 congressional election, and immediately predates the end of the housing market collapse. The average change in nominal housing prices over this period is $-17.1 \mathrm{log}$ points (standard deviation 18.7). Counties at the $90^{\text {th }}\left(10^{\text {th }}\right)$ percentile saw housing prices rise by $2.4 \log$ points (decline by 42.8 log points) over the period. ${ }^{58}$ Recognizing that changes in local housing prices may be partly the result of unobserved regional shocks, we exclude housing prices from our baseline specifications. The peak-to-trough change in housing prices at the $\mathrm{CZ}$ level is only weakly correlated with the change in $\mathrm{CZ}$ exposure to import penetration (correlation coefficient of 0.16). This modest positive correlation is the result of more trade-exposed CZs having had smaller run-ups in housing prices during the mid 2000s and therefore smaller run-downs after 2006. Over the longer 1999-2011 interval, this correlation is equal to a negligible -0.08 .

\footnotetext{
${ }^{57}$ The Bartik shock is constructed based on civilian employment of individuals age 16-64 who do not live in institutional group quarters. The data are constructed using the 2000 U.S. Census and the pooled 2009-2011 American Community Surveys (Ruggles, Genadek, Goeken, Grover, and Sobek, 2015).

${ }^{58}$ These figures correspond to changes in house prices CZs in our sample of 3,504 county-district cells. Where a CZ is included in multiple electoral districts, it contributes multiple observations to this calculation.
} 
Figure A1: Vote Shares for Elected Representatives by Party

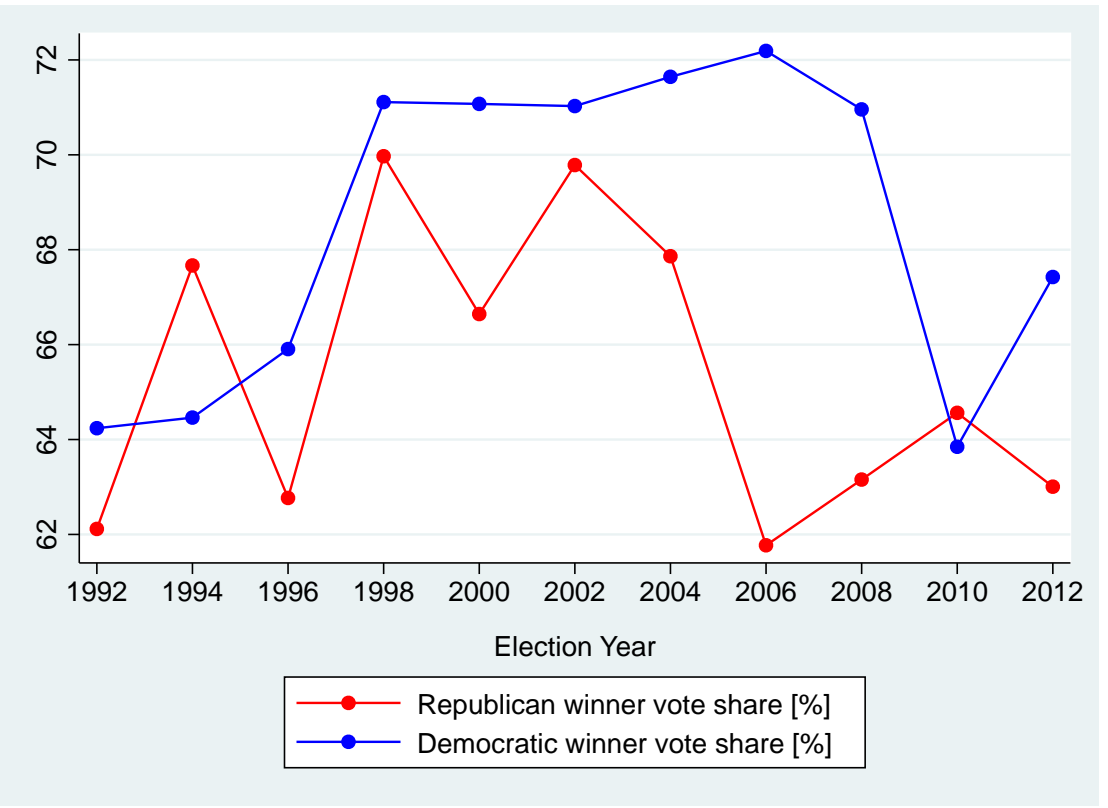

Figure A2: County-District Cells for the 12th Congressional District of North Carolina

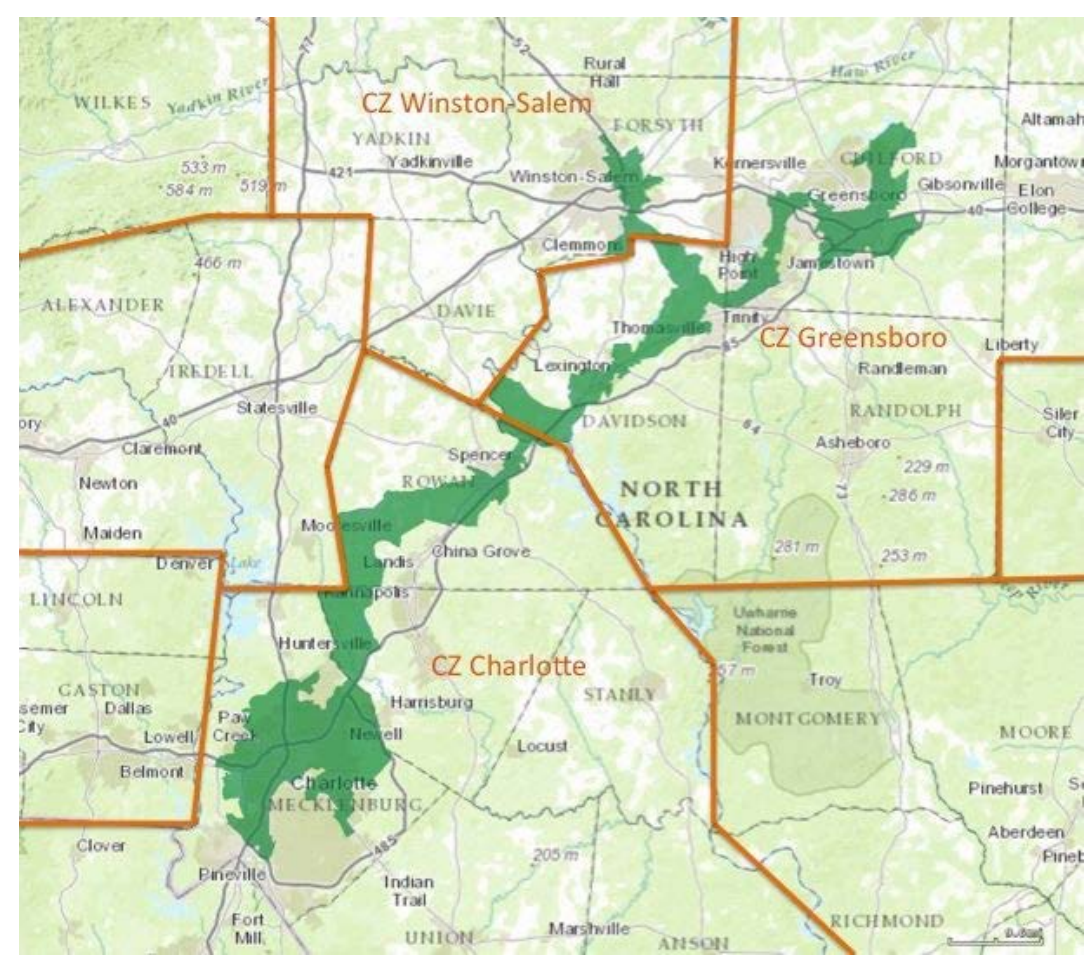


Figure A3: Import Exposure and Changes in Parties, Representatives and Political Positions of Election Winners by Subperiod

(a) Change in Political Party and Ideological Affiliation of Election Winner, 2002-2004/2006/2008/2010
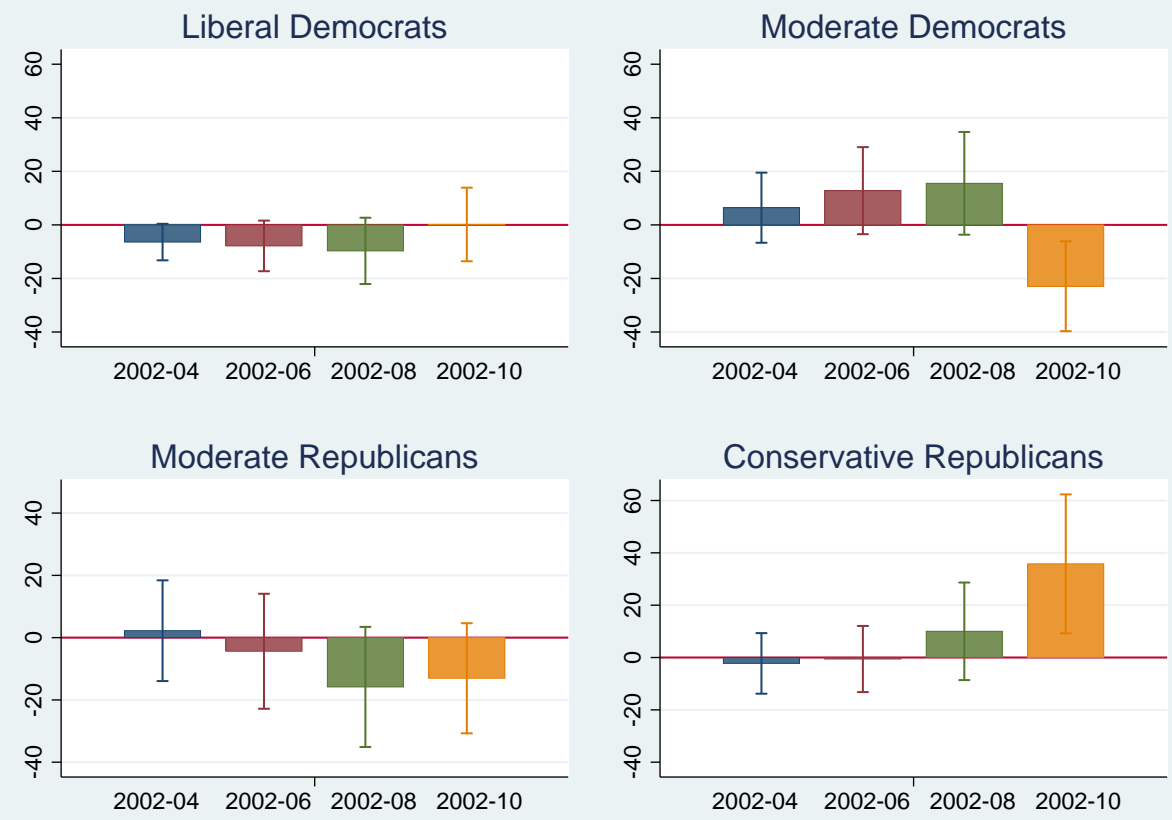

(b) Cumulative Changes in Political Party and Identity of Representatives, 2002-2004/2006/2008/2010
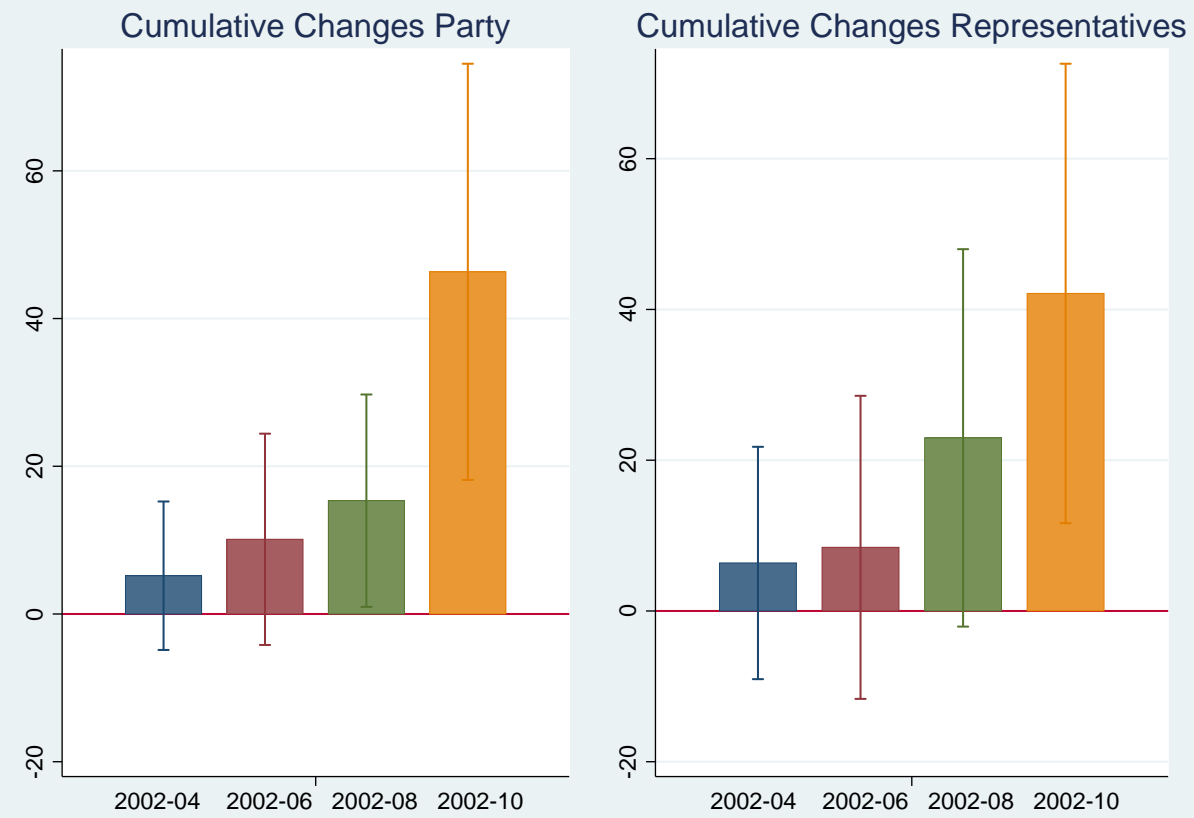
Table A1: Questions Comprising the 10-Item Pew Ideological Consistency Scale

\section{Conservative Position}

(1)

1

Government regulation of business

usually does more harm than good

2 Government is almost always wasteful and inefficient

3 Poor people today have it easy because they can get government benefits without doing anything in return

4 The government can't afford to do much more to help the needy

5 Blacks who can't get ahead in this country are mostly responsible for their own condition

6 Immigrants today are a burden on our country because they take our jobs, housing and health care

7 Most corporations make a fair and reasonable amount of profit

8 Stricter environmental laws and regulations cost too many jobs and hurt the economy

9 The best way to ensure peace is through military strength

10 Homosexuality should be discouraged by society

\section{Liberal Position}

(2)

Government often does a better job than people give it credit for

Government regulation of business is necessary to protect the public interest

Poor people have hard lives because government benefits don't go far enough to help them live decently

The government should do more to help needy Americans, even if it means going deeper into debt

Racial discrimination is the main reason why many black people can't get ahead these days

Immigrants today strengthen our country because of their hard work and talents

Good diplomacy is the best way to ensure peace

Business corporations make too much profit

Stricter environmental laws and reulations are worth the cost

Homosexuality should be accepted by society

Pew Ideological Consistency Scale, adminstered 1994 though present. Individual questions were recoded as “-1” for a liberal response, “+1" for a conservative response, " 0 ” for other (don't know/refused/volunteered) responses. Scores on the full scale range from -10 (liberal responses to all 10 questions) to +10 (conservative responses to all 10 questions). Documentation available at http://www.people-press.org/2014/06/12/appendix-a-the-ideologicalconsistency-scale/ (accessed 11/23/2017) 
Table A2: Share of Population by Pew Ideology Score and by Race/Ethnicity

\begin{tabular}{|c|c|c|c|c|}
\hline Year & $\begin{array}{c}\text { Mean Score } \\
(1)\end{array}$ & $\begin{array}{c}\% \text { Liberal } \\
(2) \\
\end{array}$ & $\begin{array}{c}\% \text { Moderate } \\
(3)\end{array}$ & $\begin{array}{c}\% \text { Conserv } \\
(4) \\
\end{array}$ \\
\hline & \multicolumn{4}{|c|}{ A. Non-Hispanic Whites } \\
\hline 2004 & -0.63 & 30.9 & 47.0 & 22.2 \\
\hline 2011 & 0.39 & 27.1 & 38.8 & 34.1 \\
\hline 2014 & 0.02 & 30.9 & 36.0 & 33.1 \\
\hline 2015 & 0.08 & 31.0 & 34.0 & 34.9 \\
\hline$\Delta 2004-15$ & 0.71 & 0.16 & -12.9 & 12.8 \\
\hline & \multicolumn{4}{|c|}{ B. Hispanics and Non-Whites } \\
\hline 2004 & -1.66 & 37.7 & 52.9 & 9.4 \\
\hline 2011 & -1.87 & 40.6 & 49.2 & 10.1 \\
\hline 2014 & -1.94 & 42.4 & 46.5 & 11.2 \\
\hline 2015 & -2.01 & 44.3 & 44.9 & 10.8 \\
\hline$\Delta 2004-15$ & -0.35 & 6.5 & -8.0 & 1.5 \\
\hline
\end{tabular}

Notes: The Pew Ideology score ranges from -10 (most liberal to +10 (most conservative). Columns 2-4 define liberals as those with scores of -10 to -3 , moderates as those with scores from -2 to 2 , and conservatives as those with scores from 3 to 10 . Sample sizes for survey participants who reside in the 48 mainland states and who have complete demographic information are 1,994 in 2004, 3,016 in 2011, 9,868 in 2014, and 5,907 in 2015. Observations are weighted by survey weights. 
Table A3: Sample Selection: U.S. Congressional Districts

\begin{tabular}{|c|c|c|}
\hline & $\begin{array}{c}\text { No. Districts } \\
(1) \\
\end{array}$ & $\begin{array}{c}\% \text { of Total } \\
(2) \\
\end{array}$ \\
\hline Total Districts in U.S. Congress & 435.0 & $100 \%$ \\
\hline Excluded States & 4.0 & $1 \%$ \\
\hline $\mathrm{AK}$ & 1.0 & \\
\hline HI & 2.0 & \\
\hline VT & 1.0 & \\
\hline Inconsistently Observed Cells & 14.8 & $3 \%$ \\
\hline TX & 9.3 & \\
\hline GA & 5.5 & \\
\hline Total Districts in Sample & 416.2 & $96 \%$ \\
\hline \multicolumn{3}{|c|}{$\begin{array}{l}\text { The sample excludes Alaska and Hawaii where the definition of Commuting Zones is } \\
\text { difficult, and the at-large district of Vermont, which was the only district represented } \\
\text { by a congressman without party affiliation during the sample period. It also excludes } \\
\text { county-district cells that are not continuously observed over time due to district } \\
\text { rezoning in the states of Texas and Georgia. The omitted areas correspond to about } \\
1 / 3 \text { of the districts in each of these states. }\end{array}$} \\
\hline
\end{tabular}

Table A4: Correlations between DW-Nominate Score and issue-specific W-Nominate Scores

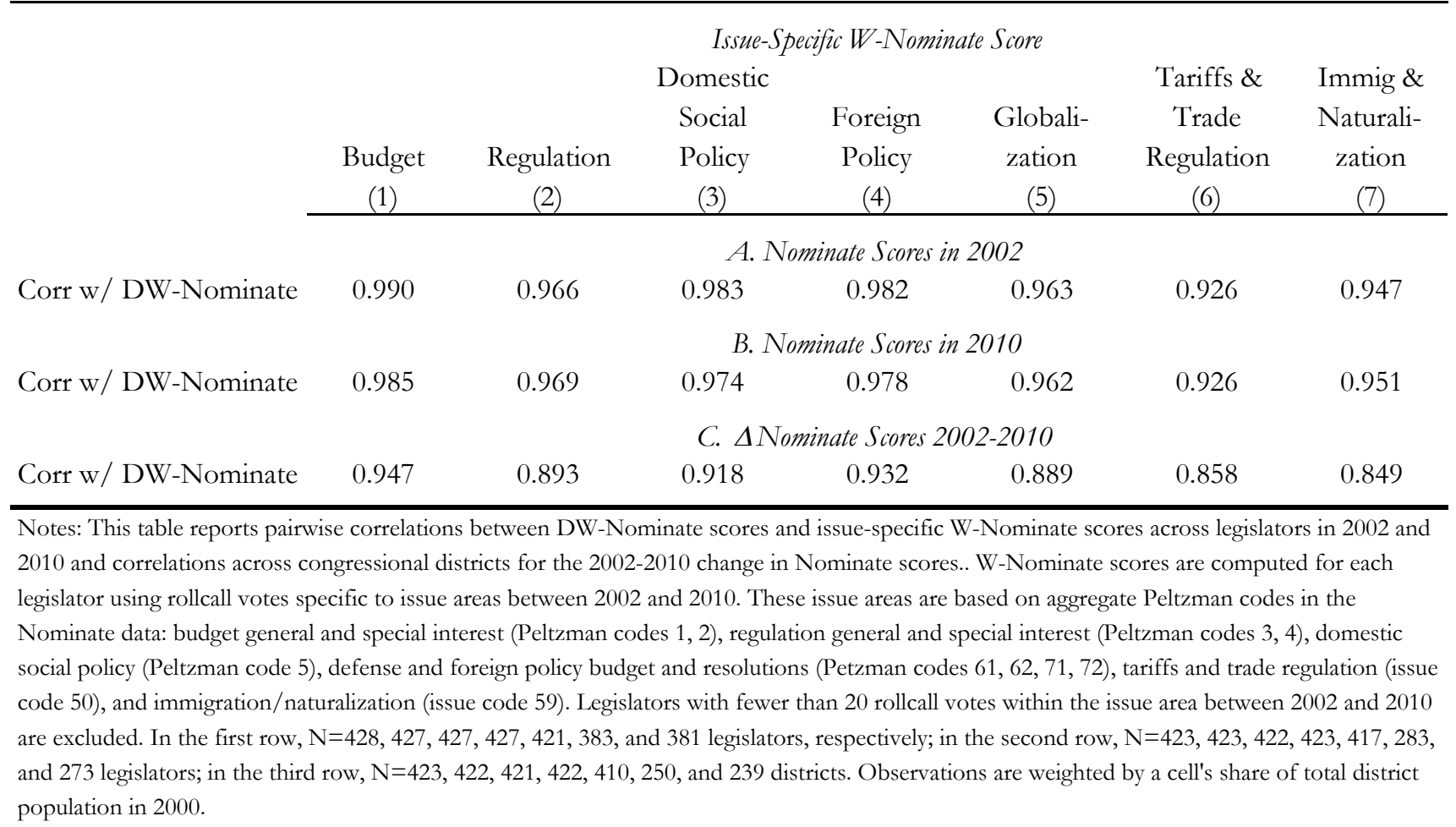


Table A5: Summary Statistics: Import Shocks.

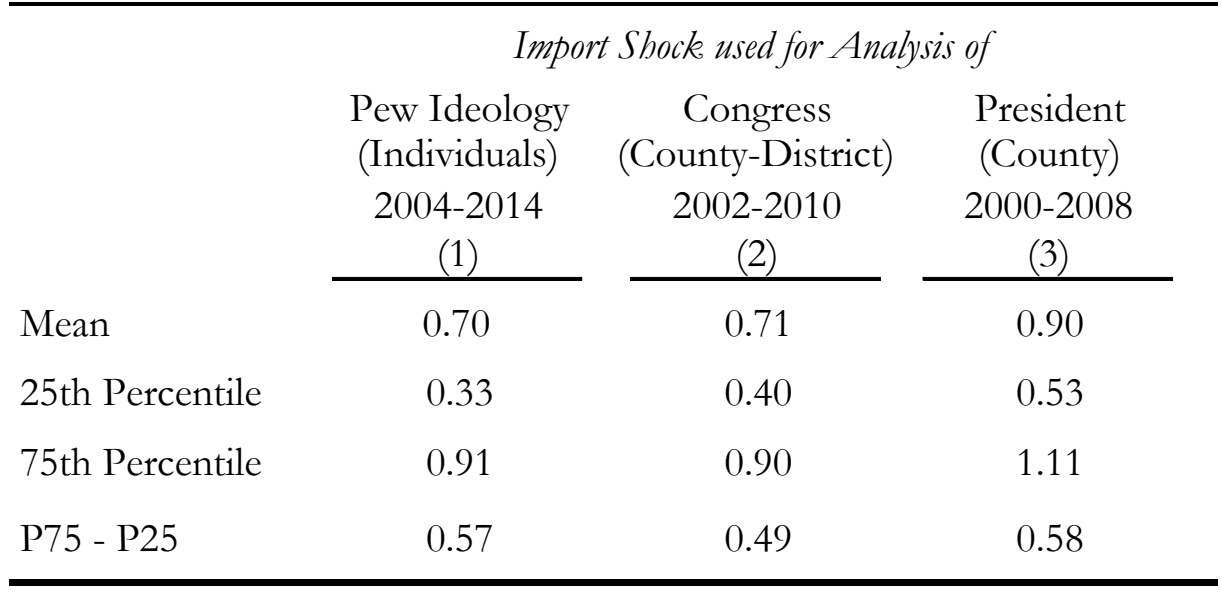

Notes: $\mathrm{N}=17,706$ respondents of the Pew survey in column 1, weighted by a respondent's share in the total individual survey weights of a period. $\mathrm{N}=3,504$ district* county cells in column 2 , weighted by a cell's share of total district population in 2000. $\mathrm{N}=3,063$ counties in column 3, weighted number of votes in the 2000 presidential election. All import shocks are defined at the commuting zone level. 
Table A6: Import Exposure and Change in Vote Share 2000-2010 for Party that Won the 2002 Election. Dependent Variable: Percentage Change in Vote Share for 2002 Winning Party.

\begin{tabular}{|c|c|c|c|c|c|c|c|c|c|c|c|c|c|}
\hline \multirow[b]{3}{*}{$\Delta \mathrm{CZ}$ Import Penetration } & $O L S$ & \multicolumn{12}{|c|}{ 2SLS Second State Estimates } \\
\hline & $(1)$ & \multicolumn{2}{|l|}{$(2)$} & (3) & \multicolumn{3}{|c|}{ (4) } & \multicolumn{2}{|c|}{ (5) } & \multicolumn{2}{|l|}{$(6)$} & \multicolumn{2}{|l|}{$(7)$} \\
\hline & $\begin{array}{l}-0.07 \\
(1.21)\end{array}$ & $\begin{array}{l}-3.13 \\
(2.27)\end{array}$ & & $\begin{array}{l}-3.10 \\
(1.80)\end{array}$ & $\sim$ & $\begin{array}{l}-2.55 \\
(1.53)\end{array}$ & $\sim$ & $\begin{array}{l}-5.42 \\
(2.72)\end{array}$ & $*$ & $\begin{array}{l}-6.30 \\
(2.40)\end{array}$ & $* *$ & $\begin{array}{l}-7.05 \\
(2.69)\end{array}$ & $* *$ \\
\hline 2002 Election Controls & & & & yes & & yes & & yes & & yes & & yes & \\
\hline 2002 Nominate Controls & & & & & & yes & & yes & & yes & & yes & \\
\hline 2002 Ind/Occ Controls & & & & & & & & yes & & yes & & yes & \\
\hline 2002 Demogr Controls & & & & & & & & & & yes & & yes & \\
\hline \multirow[t]{2}{*}{ Census Division Trends } & & & & & & & & & & & & yes & \\
\hline & & \multicolumn{12}{|c|}{ 2SLS First State Estimates } \\
\hline $\begin{array}{l}\Delta \text { Predicted CZ Import } \\
\text { Penetration }\end{array}$ & & $\begin{array}{c}0.40 \\
(0.07)\end{array}$ & $* *$ & $\begin{array}{l}0.40 \\
(0.06)\end{array}$ & $* *$ & $\begin{array}{c}0.40 \\
(0.06)\end{array}$ & $* *$ & $\begin{array}{c}0.21 \\
(0.05)\end{array}$ & $* *$ & $\begin{array}{c}0.21 \\
(0.05)\end{array}$ & $* *$ & $\begin{array}{c}0.20 \\
(0.05)\end{array}$ & $* *$ \\
\hline F-statistic & & 38.01 & $* *$ & 39.32 & $* *$ & 39.65 & $* *$ & 15.21 & $* *$ & 15.12 & $* *$ & 13.09 & $* *$ \\
\hline \multirow[t]{2}{*}{ R-squared } & & 0.39 & & 0.39 & & 0.39 & & 0.55 & & 0.57 & & 0.58 & \\
\hline & & \multicolumn{12}{|c|}{ OLS Reduced Form Estimates } \\
\hline $\begin{array}{l}\Delta \text { Predicted CZ Import } \\
\text { Penetration }\end{array}$ & & $\begin{array}{l}-1.26 \\
(0.80)\end{array}$ & & $\begin{array}{l}-1.25 \\
(0.66)\end{array}$ & $\sim$ & $\begin{array}{l}-1.02 \\
(0.58)\end{array}$ & $\sim$ & $\begin{array}{l}-1.13 \\
(0.55)\end{array}$ & $*$ & $\begin{array}{l}-1.32 \\
(0.52)\end{array}$ & $*$ & $\begin{array}{l}-1.38 \\
(0.57)\end{array}$ & $*$ \\
\hline R-squared & & 0.23 & & 0.48 & & 0.52 & & 0.53 & & 0.56 & & 0.58 & \\
\hline
\end{tabular}

Notes: $\mathrm{N}=3,504$ County*District cells. The 2SLS models in columns 2 to 6 instrument for the change in Chinese import penetration in the US using 'predicted CZ import penetration' which is constructed using the change in other developed countries' imports from China, and whose mean (s.d.) is 1.25 (0.80). The 2002 election controls in column 3 include a dummy for the party of the 2002 winner, interacted with a dummy for unopposed elections and with the vote share of the winning party. The 2002 Nominate controls in column 4 are the Nominate score of the 2002 election winner based on votes cast during the 2003-2005 Congressional period Industry, interacted with a dummy for the party of the 2002 election winner. Industry and occupation controls in column 5 are measured at the CZ level and comprise the share of manufacturing in total employment (from the 2000 County Business Patterns data), as well as routine share and offshorability among occupations (based on Autor and Dorn (2013) and derived from 2000 Census data). Demographic controls in column 6 comprise the percentage of a county's population in 9 age and 4 racial groups, as well as the population shares that are female, college-educated, foreign-born, and Hispanic. Column 7 also includes Census division dummies that allow for different time trends across the 9 geographical Census divisions. Observations are weighted by a cell's share of total district population in 2000 , and standard errors are two-way clustered on CZs and Congressional Districts. $\sim \mathrm{p} \leq 0.10,{ }^{*} \mathrm{p} \leq 0.05,{ }^{* *} \mathrm{p} \leq 0.01$. 
Table A7: Mean Changes in Nominate Scores $(\times 100)$ by Change in Election Outcome 2002-2010, and Decomposition of Components to Total Observed Change

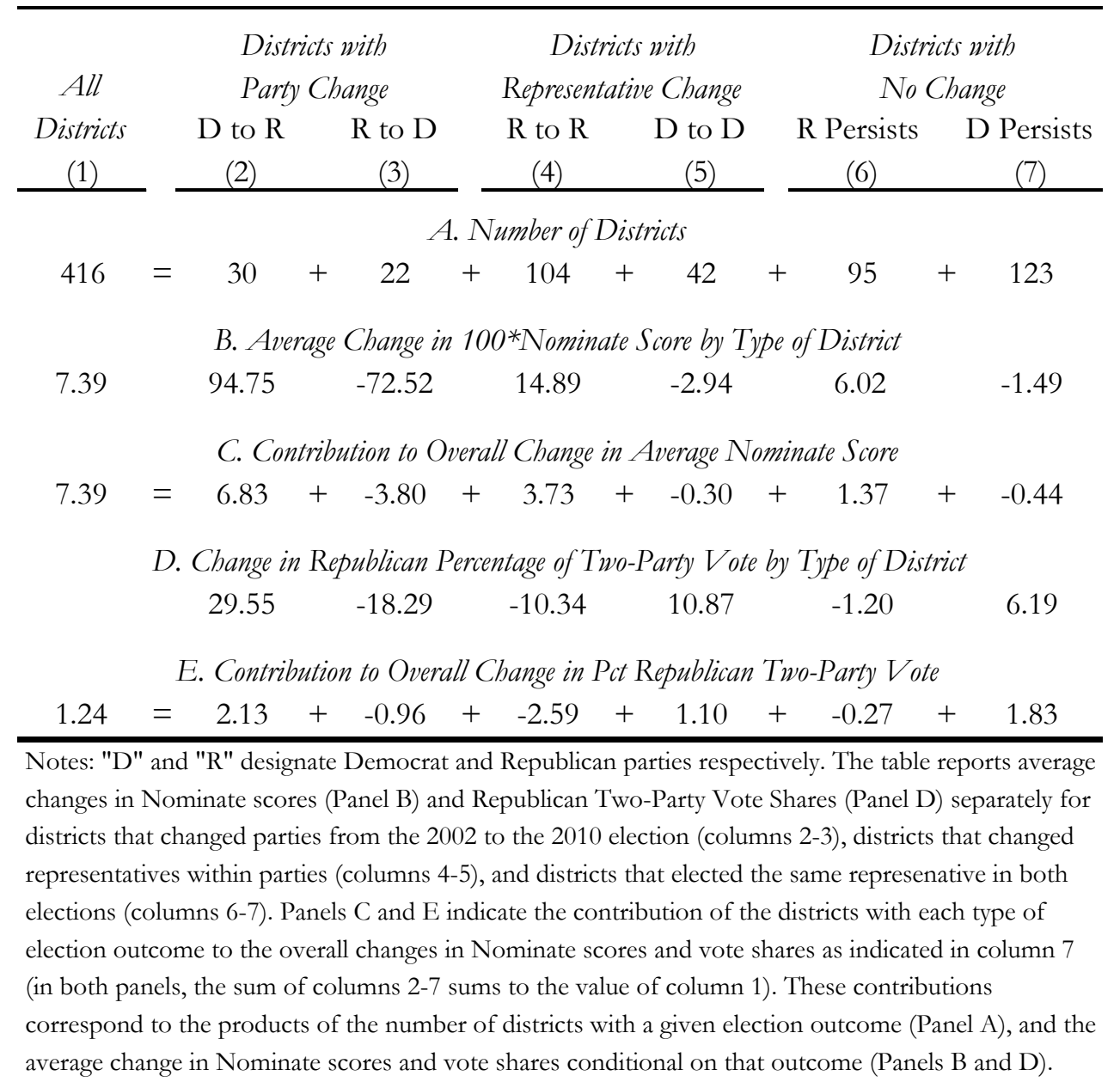


Table A8: Import Exposure and Change in Political Position of Election Winner 2002-2010: Alternative Specifications (Dependent Variable: $100 \times$ Level or Change of Ideological Affiliation of Office-Holder)

\begin{tabular}{|c|c|c|c|c|c|c|c|}
\hline & $\begin{array}{c}\text { Liberal } \\
\text { Democrat } \\
(1)\end{array}$ & & $\begin{array}{c}\text { Moderate } \\
\text { Democrat } \\
(2)\end{array}$ & & $\begin{array}{c}\text { Moderate } \\
\text { Republican } \\
\text { (3) }\end{array}$ & $\begin{array}{c}\text { Conservative } \\
\text { Republican } \\
(4)\end{array}$ & \\
\hline A. No Nominate 2002 Control & $\begin{array}{c}0.59 \\
(6.62)\end{array}$ & A. C & $\begin{array}{c}\text { utcomes in Fin } \\
-23.61 \\
(11.54)\end{array}$ & Dif & $\begin{array}{c}\text { ferences } 2002-13.48 \\
-(9.92)\end{array}$ & $\begin{array}{c}36.49 \\
(14.13)\end{array}$ & $* *$ \\
\hline B. Linear Nominate & $\begin{array}{c}0.53 \\
(6.65)\end{array}$ & & $\begin{array}{c}-23.43 \\
(9.46)\end{array}$ & $*$ & $\begin{array}{r}-13.74 \\
(9.62)\end{array}$ & $\begin{array}{c}36.65 \\
(15.37)\end{array}$ & * \\
\hline C. Quadratic Nominate & $\begin{array}{c}0.61 \\
(6.91)\end{array}$ & & $\begin{array}{c}-23.54 \\
(8.69)\end{array}$ & $* *$ & $\begin{array}{r}-13.89 \\
(9.04)\end{array}$ & $\begin{array}{c}36.83 \\
(13.89)\end{array}$ & $* *$ \\
\hline D. Linear Nominate x Party (Primary Spec) & $\begin{array}{c}0.17 \\
(7.01)\end{array}$ & & $\begin{array}{c}-22.91 \\
(8.56)\end{array}$ & $* *$ & $\begin{array}{c}-13.04 \\
(9.02)\end{array}$ & $\begin{array}{c}35.79 \\
(13.54)\end{array}$ & $* *$ \\
\hline E. Quadratic Nominate x Party & $\begin{array}{c}1.45 \\
(6.61)\end{array}$ & & $\begin{array}{c}-22.78 \\
(8.42)\end{array}$ & $* *$ & $\begin{array}{r}-13.67 \\
(9.17)\end{array}$ & $\begin{array}{c}34.99 \\
(12.69)\end{array}$ & $* *$ \\
\hline F. 4 Nominate Categories & $\begin{array}{c}4.47 \\
(6.23)\end{array}$ & & $\begin{array}{c}-28.69 \\
(8.73)\end{array}$ & $* *$ & $\begin{array}{l}-8.22 \\
(7.49)\end{array}$ & $\begin{array}{c}32.44 \\
(13.55)\end{array}$ & * \\
\hline G. Linear x Party +4 Categories & $\begin{array}{c}7.45 \\
(5.05)\end{array}$ & & $\begin{array}{c}-28.79 \\
(8.73)\end{array}$ & $* *$ & $\begin{array}{l}-7.84 \\
(7.42)\end{array}$ & $\begin{array}{c}29.18 \\
(11.74)\end{array}$ & * \\
\hline A. No Nominate 2002 Controls & $\begin{array}{c}8.63 \\
(9.56)\end{array}$ & & $\begin{array}{c}\text { B. Outcom } \\
-31.64 \\
(9.15)\end{array}$ & $\begin{array}{l}\text { in } 2 \\
* *\end{array}$ & $\begin{array}{c}010 \text { Levels } \\
-5.98 \\
(7.61)\end{array}$ & $\begin{array}{c}29.00 \\
(14.31)\end{array}$ & * \\
\hline B. Linear Nominate & $\begin{array}{c}8.79 \\
(7.75)\end{array}$ & & $\begin{array}{c}-31.70 \\
(9.35)\end{array}$ & $* *$ & $\begin{array}{l}-5.84 \\
(7.46)\end{array}$ & $\begin{array}{c}28.75 \\
(11.66)\end{array}$ & $*$ \\
\hline C. Quadratic Nominate & $\begin{array}{c}8.57 \\
(5.70)\end{array}$ & & $\begin{array}{c}-31.51 \\
(9.78)\end{array}$ & $* *$ & $\begin{array}{l}-5.76 \\
(7.29)\end{array}$ & $\begin{array}{c}28.70 \\
(11.95)\end{array}$ & * \\
\hline D. Linear Nominate x Party (Primary Spec) & $\begin{array}{c}9.81 \\
(5.56)\end{array}$ & $\sim$ & $\begin{array}{l}-32.56 \\
(10.06)\end{array}$ & $* *$ & $\begin{array}{l}-6.24 \\
(7.33)\end{array}$ & $\begin{array}{c}28.98 \\
(12.03)\end{array}$ & * \\
\hline E. Quadratic Nominate x Party & $\begin{array}{c}9.36 \\
(5.58)\end{array}$ & $\sim$ & $\begin{array}{c}-30.69 \\
(8.87)\end{array}$ & $* *$ & $\begin{array}{l}-6.84 \\
(7.46)\end{array}$ & $\begin{array}{c}28.17 \\
(10.92)\end{array}$ & $* *$ \\
\hline F. 4 Nominate Categories & $\begin{array}{c}4.47 \\
(6.23)\end{array}$ & & $\begin{array}{l}-28.69 \\
(8.73)\end{array}$ & $* *$ & $\begin{array}{l}-8.22 \\
(7.49)\end{array}$ & $\begin{array}{c}32.44 \\
(13.55)\end{array}$ & * \\
\hline G. Linear x Party +4 Categories & $\begin{array}{c}7.45 \\
(5.05)\end{array}$ & & $\begin{array}{c}-28.79 \\
(8.73)\end{array}$ & $* *$ & $\begin{array}{l}-7.84 \\
(7.42)\end{array}$ & $\begin{array}{c}29.18 \\
(11.74)\end{array}$ & * \\
\hline
\end{tabular}

Notes: $\mathrm{N}=3,504$ County*District cells. The ideological categories of office-holders are defined as in Table 4. All models include the full set of controls in Table 3 except the Nominate score of the 2002 office-holder, which is included as specified in each row headings. Observations are weighted by a cell's share of total district population in 2000, and standard errors are two-way clustered on CZs and Congressional Districts. $\sim \mathrm{p} \leq 0.10,{ }^{*} \mathrm{p} \leq 0.05,{ }^{* *} \mathrm{p} \leq 0.01$. 
Table A9: Import Exposure and Change in Political Position of Election Winner 20022010.(Dependent Variables: $100 \times$ Change in Indicators for Election of Politician by Party and Political Position using Alternative Definition)

\begin{tabular}{|c|c|c|c|c|c|c|}
\hline \multirow[b]{3}{*}{$\begin{array}{l}\Delta \text { CZ Import } \\
\text { Penetration }\end{array}$} & \multicolumn{6}{|c|}{$\begin{array}{l}\text { AProbability 2002-2010 that } \\
\text { Winner has Given Political Orientation }\end{array}$} \\
\hline & $\begin{array}{l}\text { Moderat } \\
(1) \\
\end{array}$ & & $\begin{array}{c}\text { Liberal } \\
\text { Democrat } \\
(2) \\
\end{array}$ & $\begin{array}{c}\text { Moderate } \\
\text { Democrat } \\
\text { (3) } \\
\end{array}$ & $\begin{array}{c}\text { Moderate } \\
\text { Republican } \\
(4) \\
\end{array}$ & $\begin{array}{c}\text { Conservative } \\
\text { Republican } \\
(5) \\
\end{array}$ \\
\hline & $\begin{array}{l}-30.50 \\
(10.99)\end{array}$ & $* *$ & $\begin{array}{l}-0.15 \\
(3.39)\end{array}$ & $\begin{array}{l}-22.60 \\
(8.72)\end{array}$ & $\begin{array}{l}-7.90 \\
(8.14)\end{array}$ & $\begin{array}{c}30.65 \quad * * \\
(11.84)\end{array}$ \\
\hline Mean Outcome & -12.4 & & 1.4 & -3.4 & -9.0 & 11.0 \\
\hline Level in 2002 & 57.9 & & 6.5 & 40.5 & 17.4 & 35.6 \\
\hline
\end{tabular}

Notes: $\mathrm{N}=3,504$ County*District cells. "Liberal Democrats" and "Conservative Republicans" are here defined as politicians whose Nominate scores (multiplied by 100) are respectively below -50 or above +50 . All regressions include the full set of control variables from Table 3. Observations are weighted by a cell's share of total district population in 2000, and standard errors are two-way clustered on CZs and Congressional Districts. $\sim \mathrm{p} \leq 0.10,{ }^{*} \mathrm{p} \leq 0.05,{ }^{* *} \mathrm{p} \leq 0.01$. 
Table A10: Import Exposure and Change in Political Position of Election Winner 2002-2010. (Dependent Variables: $100 \times$ Change in Nominate Score of Winner, $100 \times$ Change in Indicators for Election of Politician by Party and Political Position)

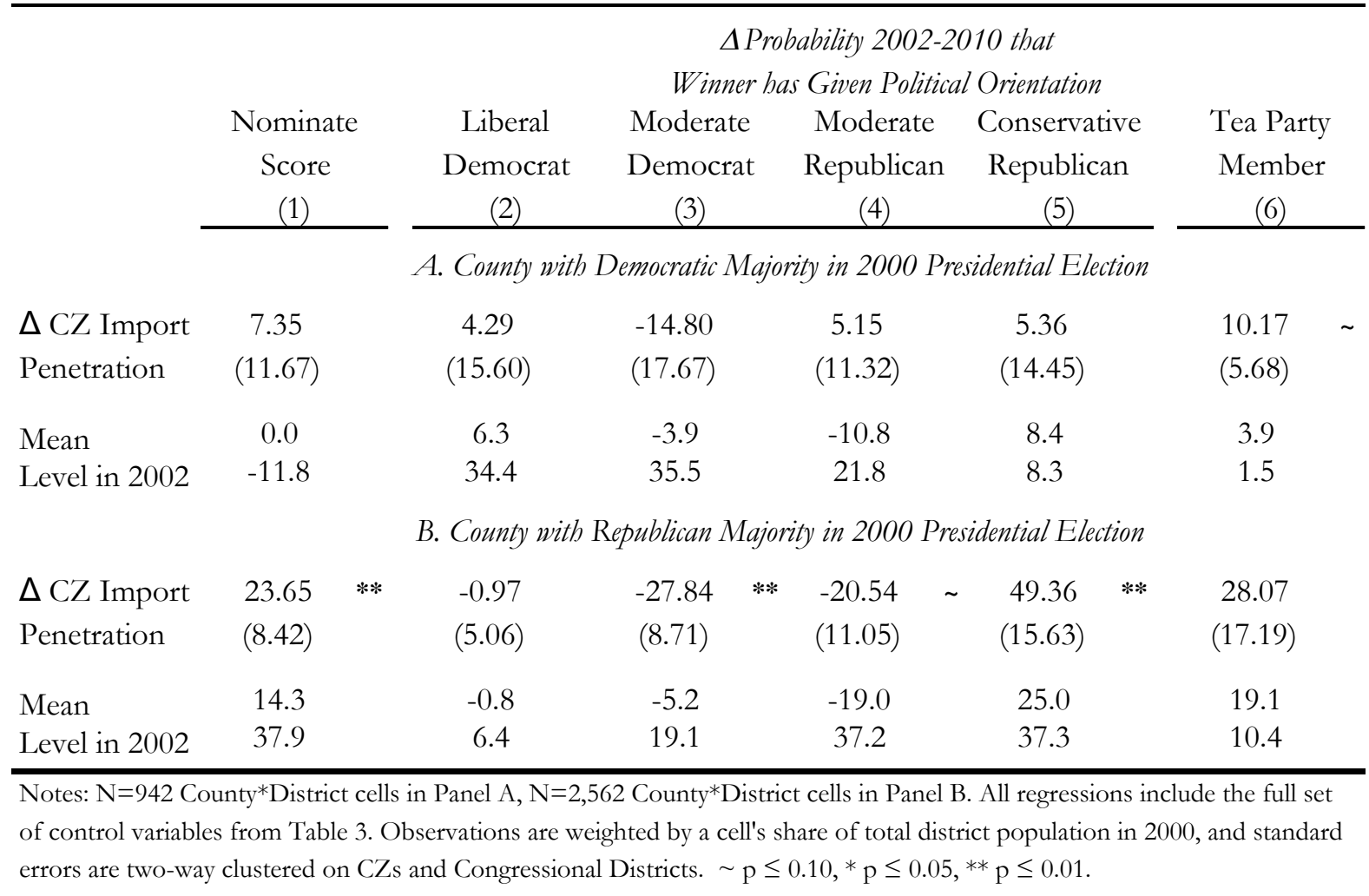

